\title{
Community mobilization for postabortion care in Kenya: Baseline evaluation report
}

Chi-Chi Undie

Population Council

Saumya RamaRao

Population Council

Follow this and additional works at: https://knowledgecommons.popcouncil.org/departments_sbsr-rh

Part of the Community Health Commons, International Public Health Commons, Maternal and Child Health Commons, Obstetrics and Gynecology Commons, Public Health Education and Promotion Commons, Social and Behavioral Sciences Commons, and the Women's Health Commons How does access to this work benefit you? Let us know!

\section{Recommended Citation}

Undie, Chi-Chi and Saumya RamaRao. 2010. "Community mobilization for postabortion care in Kenya: Baseline evaluation report," The RESPOND Project Study Series: Contributions to Global Knowledge, Report. New York: The RESPOND Project/EngenderHealth. 
The RESPOND Project Study Series:

Contributions to Global Knowledge

Report No. 2

\section{Community Mobilization for Postabortion Care in Kenya: Baseline Evaluation Report}

Chi-Chi Undie, PhD, Population Council Saumya RamaRao, PhD, Population Council

November 2010 

The RESPOND Project Study Series:

Contributions to Global Knowledge

Report No. 2

\section{Community Mobilization for Postabortion Care in Kenya: Baseline Evaluation Report}

Chi-Chi Undie, PhD, Population Council

Saumya RamaRao, PhD, Population Council

November 2010

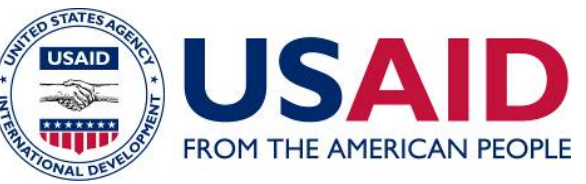


(C2010 The RESPOND Project/EngenderHealth

The RESPOND Project

c/o EngenderHealth

440 Ninth Avenue

New York, NY 10001 U.S.A.

Telephone: 212-561-8000

Fax: 212-561-8067

e-mail: info@respondproject.org

www.respondproject.org

This publication is made possible by the generous support of the American people through the Office of Population and Reproductive Health, U.S. Agency for International Development (USAID), under the terms of cooperative agreement GPO-A-000-08-00007-00. The contents are the responsibility of the RESPOND Project and do not necessarily reflect the views of USAID or the United States Government.

This work is licensed under the Creative Commons AttributionNoncommercial-Share Alike 3.0 Unported License. To view a copy of this license, visit http://creativecommons.org/licenses/by-nc-sa/3.0/.

Printed in the United States of America. Printed on recycled paper.

Suggested citation: Undie, C.-C., and RamaRao, S. 2010. Community mobilization for postabortion care in Kenya: Baseline evaluation report. The RESPOND Project Study Series: Contributions to Global Knowledge-Report No. 2. New York: EngenderHealth/The RESPOND Project. 


\section{Contents}

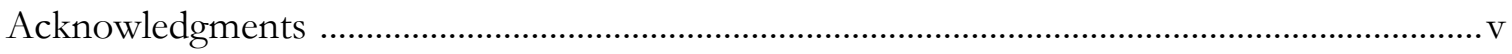

Acronyms /Abbreviations .................................................................................................... vii

Executive Summary ............................................................................................................ ix

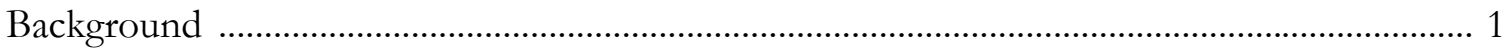

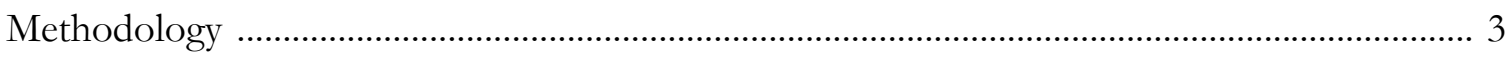

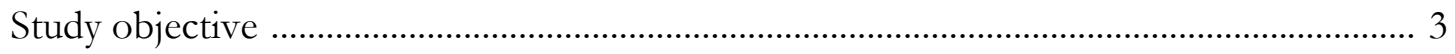

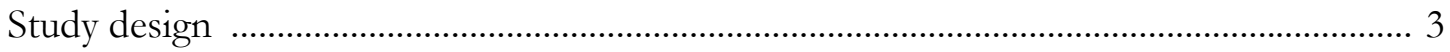

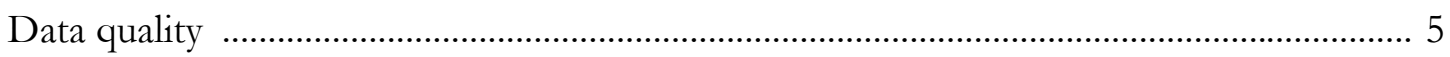

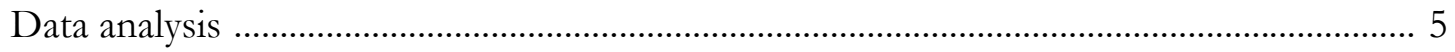

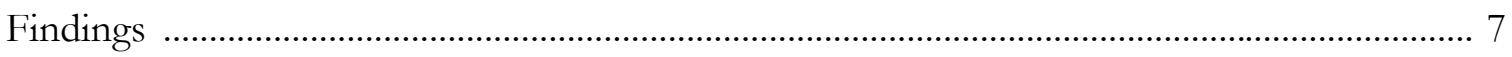

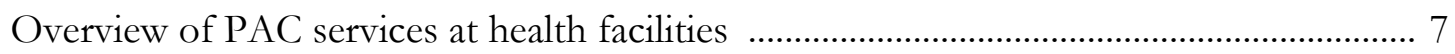

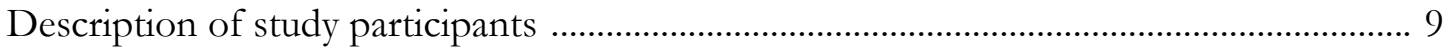

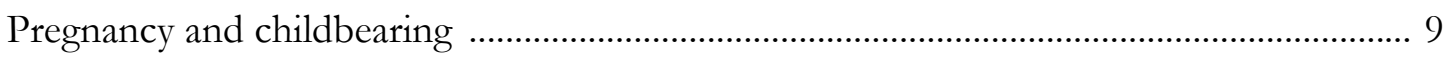

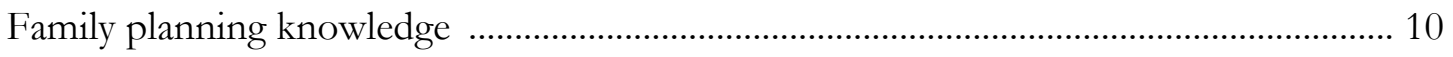

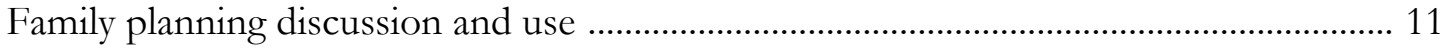

Knowledge and utilization of health services ..................................................................... 14

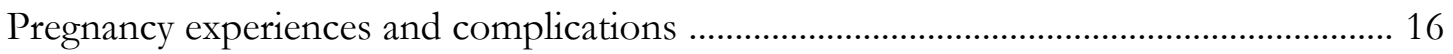

Perceptions of quality of care for bleeding in the first half of pregnancy ........................ 20

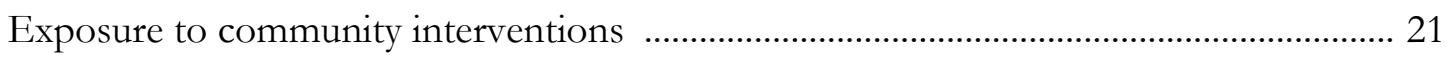

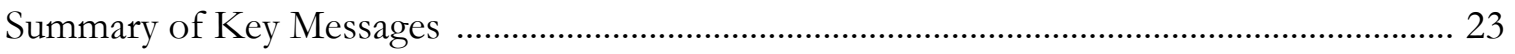

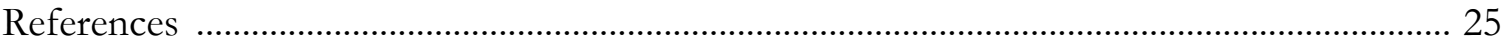

\section{Appendixes}

Appendix A: Baseline Community Survey Instrument ............................................................ 29

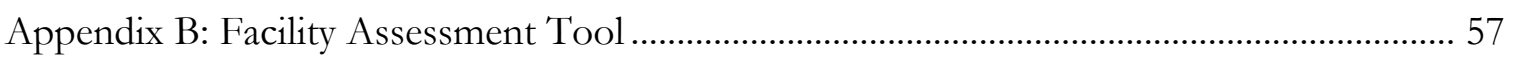

\section{Tables}

Table 1. Community unit intervention and control sites ........................................................ 4

Table 2. Population sizes of community units and health facilities

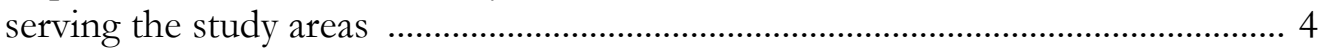

Table 3. Health services and referral mechanisms offered at study area health facilities, by intervention and control group status .................................................. 7

Table 4. Readiness of health facilities to offer PAC services ……………............................. 8

Table 5. Respondent and partner demographics ................................................................. 9

Table 6. Measures of pregnancy and childbearing in study areas ...................................... 10

Table 7. Family planning knowledge .................................................................................. 11 
Table 8. Source of exposure (heard/seen/read) to information

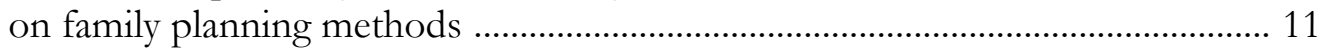

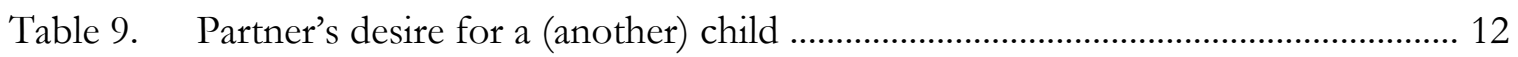

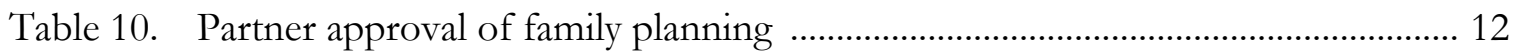

Table 11. Respondent's desire for a (another) child ............................................................... 13

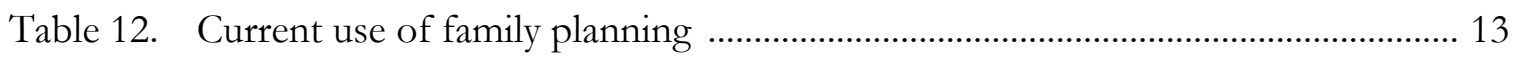

Table 13. Main reasons for not using family planning ............................................................ 14

Table 14. Perceived access points for family planning methods

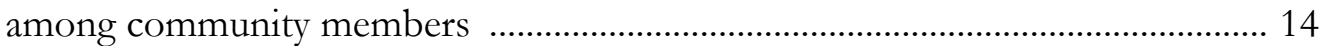

Table 15. Perceived access points for ANC among community members ......................... 15

Table 16. Perceived access points for delivery care among community members............... 15

Table 17. Months of gestation at which respondents made their first ANC visit during their last or current pregnancy ...................................................................... 16

Table 18. Attendant at last delivery ........................................................................................... 16

Table 19. Percentage of respondents knowing various danger signs or complications in early pregnancy .................................................................... 17

Table 20. Percentage of respondents who experienced bleeding in the first few months of pregnancy and percentage who sought care .................................. 17

Table 21. Percentage knowing where to access care in case of bleeding

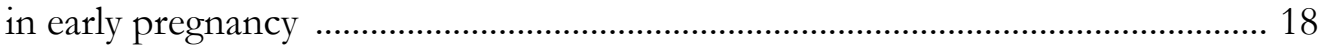

Table 22. Place where care was sought for bleeding in early pregnancy ............................... 18

Table 23. Mode of transportation to place where care was sought for bleeding in early pregnancy ................................................................................ 18

Table 24. Partner support for obtaining PAC services ........................................................ 19

Table 25. Reasons for not seeking care for bleeding in early pregnancy ............................... 19

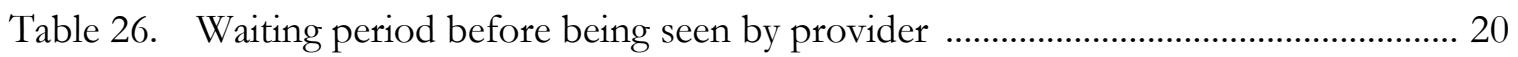

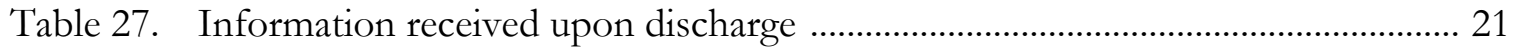

Table 28. Knowledge of CHEWs or CHWs ........................................................................... 22

Table 29. Participation in NGO/community group meetings/activities or CHW meetings/activities focused on bleeding in the first half of pregnancy in the past year 


\section{Acknowledgements}

This study was made possible through the generous support of the American people through the United States Agency for International Development (USAID). The contents are the responsibility of the RESPOND Project partner the Population Council and do not necessarily reflect the views of USAID or the United States Government.

Our thanks go to colleagues on the RESPOND team, especially Lynn Van Lith, Jane Wickstrom, Laura Subramanian, Hannah Searing, Sara Malakoff, and Mercy Wahome; to Carolyn Curtis of USAID's Post-Abortion Care Program; to Population Council staff in Nairobi (especially Ian Askew, Francis Onyango, Erick Oweya, Harriet Birungi, and Wilson Liambila); and to the Nakuru Branch of the Society of Women and AIDS in Kenya (SWAK).

We are deeply appreciative of the assistance of the District Health Management Team in Naivasha District, led by the District Medical Officer of Health, Dr. J.K. Lenai, which facilitated the successful implementation of the study. We are grateful to the team of research assistants whose data collection assistance made the study possible. We also thank all of the providers and the local women who agreed to be interviewed for this evaluation.

This report was edited by Michael Klitsch and was formatted by Elkin Konuk. 



\section{Acronyms and Abbreviations}

$\begin{array}{ll}\text { ANC } & \text { antenatal care } \\ \text { CHEW } & \text { community health extension worker } \\ \text { CHW } & \text { community health worker } \\ \text { COMMPAC } & \text { Community Mobilization for Postabortion Care } \\ \text { IPPF } & \text { International Planned Parenthood Federation } \\ \text { IUD } & \text { intrauterine device } \\ \text { MOH } & \text { Ministry of Health } \\ \text { NGO } & \text { nongovernmental organization } \\ \text { PAC } & \text { postabortion care } \\ \text { SWAK } & \text { Society for Women and AIDS in Kenya } \\ \text { TBA } & \text { traditional birth attendant } \\ \text { USAID } & \text { U.S. Agency for International Development }\end{array}$





\section{Executive Summary}

Maternal health complications, including those arising from unsafe abortion and miscarriage, are a leading cause of morbidity among women in Kenya. The Rift Valley Province in particular has had the highest number of cases of abortion-related outpatient morbidity in the country since at least 2003. These realities necessitate interventions to prevent unintended or unwanted pregnancies and to ensure access to quality care for women with postabortion complications.

In response to this need, the RESPOND Project designed an intervention package aimed at increasing awareness and use of postabortion care (PAC) services ${ }^{1}$ and improving family planning, reproductive health, and maternal health outcomes. As part of the intervention, RESPOND is working with districts and communities to: strengthen service delivery points to provide PAC services; conduct community mobilization to improve community involvement and knowledge on the prevention and treatment of PAC; build community capacity to address PAC needs; and encourage involvement of those most marginalized and most affected by postabortion complications in community action. The interventions will be carried out in selected communities in Naivasha District, Rift Valley Province, from 2010 to 2011.

This report summarizes the key results emerging from a baseline data collection exercise carried out from May to June 2010 in Naivasha District to provide a benchmark against which the RESPOND intervention may be measured during endline evaluation. The evaluation uses a quasi-experimental design with intervention and control groups covering six study sites within Naivasha District, with measurements taken at baseline and endline. The baseline data collection comprises three components - a community-based survey of approximately 600 women between the ages of 18 and 49; an inventory of all public and private health facilities in the study area $(n=11)$; and interviews with providers working at the identified facilities.

\section{Key Findings}

There is a clear need for PAC services at the evaluation sites. Although the respondents were aware of a number of danger signs in pregnancy, a significant proportion were not aware that bleeding in the first half of pregnancy is not normal or could signify a problem. Furthermore, approximately one-third of the women experiencing bleeding had not sought care, indicating that a considerable proportion of women are unaware of the life-threatening risks they face by not seeking care.

Utilization of health services during pregnancy and delivery is limited. Despite their awareness that government health facilities are a place where maternal health services may be obtained, during their last pregnancy a significant proportion of women sought their first antenatal care (ANC) check-up in the second trimester (at 5-6 months). One-third of

1 Throughout the intervention, PAC is referred to as "bleeding in the first half of pregnancy," given the sensitivities of talking about abortion and PAC in the Kenyan context. 
respondents reported delivering at home while attended by friends or relatives rather than by a skilled birth attendant.

Knowledge of family planning is high, but actual use is significantly lower. Although practically all respondents were aware of a family planning method, fewer than $50 \%$ of the women in the study were currently using a method. Of those who were not currently using a method, about $60 \%$ desired to limit future births.

Reasons for nonuse of family planning highlight the need for the intervention. Lack of knowledge of the range of methods available, a lack of specific knowledge of individual methods, and fear of side effects were among the key reasons for nonuse of contraception. The largest percentage of respondents reported that their main reason for not using family planning was their unmarried status. A significant proportion of respondents were undecided about when they wanted to conceive again.

Exposure to community interventions in general is low. Few community interventions were known by respondents, and their knowledge of the community health extension workers and community health workers in their neighborhoods was also low.

Health facilities in Naivasha could feasibly offer PAC services. Although PAC services are currently not being offered at the surveyed health facilities (the vast majority of which are Level II health facilities), all of the facilities could potentially provide PAC services if they received some strengthening, particularly training of providers in the provision of these services.

Government health facilities are patronized by a considerable proportion of women. Women identify and seek care at government health facilities for a range of services, including bleeding in the first half of pregnancy, PAC, ANC, delivery, and family planning.

In summary, the results of the baseline survey provide a general picture of community knowledge and behaviors and the range of service options that are available. These details are relevant for honing and refining the planned interventions under the RESPOND Project. Based on the findings from the baseline evaluation, the following intervention strategies are recommended:

- Prioritizing a focus on knowledge of bleeding danger signs due to either miscarriage or unsafe abortion.

- Building on existing community knowledge of government health facilities by linking communities and health services to increase utilization of health services.

- Fostering community awareness in regard to seeking appropriate care at relevant times over the course of pregnancy.

- Strengthening facilities to offer a full range of contraceptive choices, including long-acting and permanent methods, and to offer contraceptive services to all women seeking PAC.

- Providing women who wish to avoid pregnancies with information and methods, to promote informed choice. Creating dialogue about the need and availability of family planning methods should be pursued during community-level engagement, to address the barriers to use. As a significant proportion of respondents were undecided about when they 
wanted to conceive again, working to resolve this ambiguity would help to reduce the likelihood of unintended pregnancy.

- Focusing on young unmarried women (the largest percentage of whom reported not using family planning because of their unmarried status), who are also reported to have some of the highest rates of unsafe abortion in Kenya.

- Ensuring intensive community mobilization efforts in terms of inputs and reach. Given the low exposure of community residents to any type of community mobilization activity, the community mobilization intervention may require repeated sessions, so as to saturate the community. Efforts can also be made to include men in this process, as women reported that their partners were important decision makers in and supporters of their health. 



\section{Background}

Deaths from unsafe abortion in developing countries represent $13 \%$ of all pregnancy-related mortality and in some countries as much as $25 \%$ of maternal deaths (Curtis, Huber, \& MossKnight, 2010). A woman dies every eighth minute somewhere in a developing country due to complications arising from unsafe abortion and miscarriage. In Kenya, such maternal health complications are a leading cause of morbidity among women (KMOH, 2008). The Rift Valley Province, where Naivasha is located, has consistently had the highest number of cases of abortion-related outpatient morbidity in the country since at least 2003, with 10,958 such deaths in 2004 alone $(\mathrm{KMOH}, 2005)$. Given these staggering numbers, interventions to prevent unintended or unwanted pregnancies and to ensure access to quality care for women with postabortion complications are a public health imperative.

In response to this need, the RESPOND Project ${ }^{2}$ designed an intervention package aimed at increasing awareness and use of postabortion care (PAC) services ${ }^{3}$ and improving family planning, reproductive health, and maternal health outcomes. This package builds on efforts by the ACQUIRE Project (2005-2007) to address PAC and increase family planning uptake by focusing on the central role that communities can play in improving access to services. As part of this intervention, RESPOND is working with districts and communities to: strengthen service delivery points to provide PAC services; conduct community mobilization to improve community involvement and knowledge on the prevention and treatment of bleeding in the first half of pregnancy; build community capacity to address PAC needs; and encourage involvement in community action of those most marginalized and most affected by postabortion complications. The intervention package is guided by RESPOND's supply-demand-advocacy framework, with a specific focus on the first two components. The intervention will be carried out in selected communities in Naivasha District from 2010 to 2011.

Between May and June 2010, the Population Council collected baseline data in Naivasha, Rift Valley Province, Kenya, to assess the combined effectiveness of RESPOND's supply and demand interventions on community capacity to mobilize for improved family planning, reproductive health, and maternal health outcomes. The baseline comprises three components: a community-based survey of women between the ages of 18 and 49; an inventory of all public and private health facilities in the study area $(n=11)$; and interviews with providers working in the identified facilities. This report summarizes the key results emerging from the baseline evaluation.

2 The RESPOND Project (Responding to the Need for Family Planning through Expanded Contraceptive Choices and Program Services) is a five-year U.S. Agency for International Development (USAID) Leader with Associates Cooperative Agreement. RESPOND is led by EngenderHealth, in partnership with six other organizations: FHI, the Futures Institute, Johns Hopkins Bloomberg School of Public Health Center for Communication Programs (JHU/CCP), Meridian Group International, Inc., and the Population Council.

3 Throughout the intervention, PAC is referred to as "bleeding in the first half of pregnancy," given the sensitivities of talking about abortion and PAC in the Kenyan context. 



\section{Methodology}

\section{Study Objective}

The main objective of the baseline is to provide a benchmark against which changes to the supply and demand components ${ }^{4}$ of the RESPOND intervention may be measured at the endline survey. The intervention strategy will involve the following specific activities, which will be conducted by RESPOND's service delivery team:

1. RESPOND will train service providers (primarily clinical officers, registered nurses, and registered midwives) within Ministry of Health $(\mathrm{MOH})$ dispensaries (Level I) and health centers (Level II) in Naivasha in the management of complications related to miscarriage and unsafe abortion (bleeding in the first half of pregnancy), to respond comprehensively to potential demand for PAC services by community members. Providers at up to 11 participating health centers and dispensaries will be trained.

2. RESPOND will train staff from the Nakuru Branch of the Society for Women and AIDS in Kenya (SWAK) on the community action cycle and the approaches for training communities in Naivasha on the cycle. This will include building the capacity of SWAK to provide ongoing mentoring and support to $\mathrm{MOH}$ community health extension workers (CHEWs) and community health workers (CHWs) based in Naivasha.

3. SWAK will train Level I MOH CHEWs and CHWs to facilitate the CAC for PAC in the communities in their work areas.

4. SWAK will support trained CHEWs and CHWs in conducting community mobilization sessions in their communities.

5. SWAK will provide ongoing mentoring and support to trained CHEWs and CHWs via monthly monitoring visits and quarterly meetings with the CHEWs.

\section{Study Design}

The study used a quasi-experimental design with intervention and control groups and a baseline assessment of demand and supply issues at six study sites within Naivasha District.

Each study site is a "community unit," as defined by the $\mathrm{MOH}$, which refers to areas around which the $\mathrm{MOH}$ organizes service provision in accordance with its Community Strategy (MOH, 2006). Six community units were selected and matched based on their similarities in regard to urban-rural distribution of the population, service coverage, socioeconomic profile, and level of economic development. Three community units were randomly selected as the intervention sites, while the remaining three units serve as control sites (Table 1, page 4). Two CHEWs serve a community unit and oversee the work carried out by $50 \mathrm{CHWs}$, who are volunteers residing within each community unit.

4 The advocacy component of RESPOND's Supply-Demand-Advocacy Framework was not addressed as part of the baseline evaluation. This component will be addressed after the interventions are underway and during the endline phase of the evaluation, as by that time advocacy activities would have occurred. 


\section{Table I: Community unit intervention and control sites}

\begin{tabular}{|l|l|}
\hline Intervention & Control \\
\hline Karunga & Eburu \\
\hline Kiambogo & Maraigushu \\
\hline Longonot & Moi Ndabi \\
\hline
\end{tabular}

A second important aspect of the evaluation design is that it includes both service delivery points or health facilities and the communities served by them. Measurements taken at the health facilities at baseline will gauge their readiness to provide PAC services and the quality of these services. Further, measurements taken at the community level will provide information on knowledge levels in regard to danger signs in pregnancy, access to and quality of PAC services at the focus facilities, and uptake of PAC services.

At baseline, data collection involved a community-based survey, health facilities assessments, and provider interviews in all intervention and control study sites.

\section{Community-Based Survey}

The baseline community survey involved structured interviews with a total of 600 women aged 18-49 years who reside in the six community units covered by the project. Seven of the 600 interviews were incomplete and therefore discarded. This report is thus based on a sample size of 593. Although women and girls below the age of 18 have reproductive health issues, they were excluded from the sample, as the number in this particular age range would be too small to permit disaggregation during data analysis, and because of the attendant issues of obtaining consent from those below 18 years of age.

From each community unit in the intervention and control groups, individuals were sampled with probability proportional to the population size of the community unit (Table 2).

Table 2: Population sizes of community units and health facilities serving the study areas

\begin{tabular}{|l|c|c|c|c|c|}
\hline $\begin{array}{c}\text { Community } \\
\text { unit }\end{array}$ & $\begin{array}{c}\text { Population } \\
\text { size }\end{array}$ & $\begin{array}{c}\text { MOH } \\
\text { dispensary }\end{array}$ & $\begin{array}{c}\text { MOH } \\
\text { health center }\end{array}$ & $\begin{array}{c}\text { Private } \\
\text { medical clinic }\end{array}$ & $\begin{array}{c}\text { Faith-based } \\
\text { health center }\end{array}$ \\
\hline Eburu & 6,798 & $\mathrm{I}$ & & $\mathrm{I}$ & \\
\hline Karunga & $\mathrm{I} 2,874$ & $\mathrm{I}$ & & & \\
\hline Kiambogo & 32,450 & 2 & $\mathrm{I}$ & $\mathrm{I}$ & \\
\hline Longonot & 4,722 & $\mathrm{I}$ & & & $\mathrm{I}$ \\
\hline Maraigushu & $\mathrm{I} 0,000$ & $\mathrm{I}$ & & & \\
\hline Moi Ndabi & 7,000 & $\mathrm{I}$ & & & \\
\hline
\end{tabular}

In the first stage, four villages were randomly selected from each community unit. Within each selected village, every third household was visited, and within each household, only one female member aged 18-49 was identified for an individual interview. Selected households that did not have a female member who met this criterion were replaced with the next available household having such a member. For households with more than one female member aged 18-49, only one female respondent was identified for interview. 


\section{Facility Inventory}

An inventory of the physical infrastructure and a review of the facility records were conducted at a total of 11 public and private health facilities in the intervention and control sites, using a tool/checklist to determine improvements/alterations or additions required to accommodate PAC services, including new supplies and equipment and the availability of commodities required for PAC and family planning. At one of the facilities (Prime Medical Care, a private health facility in Kiambogo), the inventory was only partially completed, as the proprietor (who also appears to serve as the sole medical staff) was out of town throughout the fieldwork period.

\section{Health Provider Interviews}

A short, semi-structured questionnaire was developed to assess providers' knowledge, attitudes, and practices pertaining to PAC and family planning. Attempts were made to carry out interviews with providers (doctors, clinical officers, and registered nurses) at all public and private health facilities in the study areas where PAC services are offered. This occurred at the same time as the inventory.

The survey, facility inventory, and provider interviews were administered by trained research assistants.

\section{Data Quality}

Data quality checks were carried out in multiple ways. During data collection, field supervisors did a manual check of every completed interview schedule turned in by interviewers. Interview schedules with errors were rectified by revisits to the household. Second, quality checks were built in to reduce data entry errors; Epi Info ${ }^{\mathrm{TM}}$ screens were created that only allowed in-range codes and checked for skip patterns. Third, after data entry, range checks were conducted on the data to test for in-range responses. Where relevant, data entry clerks consulted with the original interview schedules to make the appropriate corrections.

Data quality was also enhanced by using the double-entry procedure. After the first round of data entry, a special program that permits the entering of data a second time was used, and each second entry was checked against the first. Any discrepancies noted during this process were corrected.

\section{Data Analysis}

The baseline community survey data were entered in Epi Info and analyzed using Stata ${ }^{\circledR}$ software. The principal procedure for data analysis involved descriptive statistics on each variable at baseline, making comparisons between the intervention and control sites and testing whether there are any significant differences (calculated as $\mathrm{p}<.05$ ).

As the facility inventory occurred at only 11 health facilities, the data collected via the facility inventory and provider tools were reviewed manually. The provider tool was to be administered only to providers at facilities where PAC services were offered. 



\section{Findings}

\section{Overview of PAC Services at Health Facilities}

At baseline, the inventory data indicated that PAC services were not being offered at any of the 11 health facilities. Furthermore, at all health facilities but one (Longonot Dispensary, in Longonot Community Unit), no providers had received PAC training. Although PAC services were unavailable among the health facilities, five of the facilities had general referral mechanisms for patient emergencies, as outlined below. Table 3 also gives an indication of the type of services offered at each facility.

Table 3: Health services and referral mechanisms offered at study area health facilities, by intervention and control status*

\begin{tabular}{|c|c|c|c|c|}
\hline Community & $\begin{array}{l}\text { Name of } \\
\text { Facility }\end{array}$ & $\begin{array}{l}\text { Type of } \\
\text { facility }\end{array}$ & Services offered & Referral mechanism \\
\hline \multicolumn{5}{|c|}{ Community Unit: Intervention } \\
\hline Karunga & $\begin{array}{l}\text { Karunga } \\
\text { Dispensary }\end{array}$ & Ministry of Health & ANC, FP, HCT, PMTCT & $\begin{array}{l}\text { Patient is escorted by a health } \\
\text { provider to a facility where } \\
\text { required services are available. }\end{array}$ \\
\hline Kiambogo & $\begin{array}{l}\text { Kiambogo } \\
\text { Dispensary }\end{array}$ & Ministry of Heath & ANC, FP, HCT, PMTCT & \\
\hline Kiambogo & $\begin{array}{l}\text { Kiptangwanyi } \\
\text { Dispensary }\end{array}$ & Ministry of Health & $\begin{array}{l}\text { ANC, ART, FP, HCT, } \\
\text { PMTCT }\end{array}$ & \\
\hline Kiambogo & $\begin{array}{l}\text { Oljurai Health } \\
\text { Center }\end{array}$ & Ministry of Health & ANC, FP, HCT, PMTCT & \\
\hline Kiambogo & $\begin{array}{l}\text { Prime Medical } \\
\text { Care }\end{array}$ & Private & $\begin{array}{l}\text { ANC, FP, HCT, HBC, } \\
\text { PMTCT }\end{array}$ & \\
\hline Longonot & $\begin{array}{l}\text { Longonot } \\
\text { Dispensary }\end{array}$ & Ministry of Health & ANC, FP, HCT, PMTCT & \\
\hline Longonot & $\begin{array}{l}\text { Holy Trinity } \\
\text { Health Center }\end{array}$ & Faith-Based & ANC, HCT, PMTCT & $\begin{array}{l}\text { Referral forms are available; } \\
\text { patient is escorted to facility } \\
\text { by a health provider. }\end{array}$ \\
\hline \multicolumn{5}{|c|}{ Community Unit: Control } \\
\hline Eburu & $\begin{array}{l}\text { Eburu } \\
\text { Dispensary }\end{array}$ & Ministry of Health & ANC, FP, HCT, PMTCT & $\begin{array}{l}\text { Telephone communication } \\
\text { between facilities }\end{array}$ \\
\hline Eburu & $\begin{array}{l}\text { Camp } \\
\text { Brethren } \\
\text { Medical Clinic }\end{array}$ & Private & ANC, FP, PMTCT & \\
\hline Maraigushu & $\begin{array}{l}\text { Maraigushu } \\
\text { Dispensary }\end{array}$ & Ministry of Health & ANC, FP, HCT, PMTCT & \\
\hline Moi Ndabi & $\begin{array}{l}\text { Moi Ndabi } \\
\text { Dispensary }\end{array}$ & Ministry of Health & ANC, FP, HCT, PMTCT & $\begin{array}{l}\text { Patient is escorted to facility } \\
\text { by a health provider }\end{array}$ \\
\hline
\end{tabular}

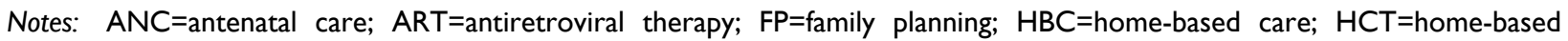
counseling and testing (HCT); PMTCT=prevention of mother-to-child transmission of HIV.

* Health facilities were identified from the Kenya Health Facilities List, July 28, 2009, Ministry of Health and Public Sanitation (www.publichealth.go.ke). 
All 11 facilities have staff (such as nurses or clinical officers) who could provide PAC services if they were trained to do so. Although this level of staff is not present at the facilities 24 hours a day, for seven out of the 10 health facilities for which we have complete data, staff are available on call at all times after normal operating hours (Table 4).

Table 4: Readiness of health facilities to offer PAC services

\begin{tabular}{|c|c|c|c|c|c|c|c|c|c|c|}
\hline & ڤั & 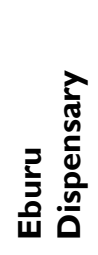 & 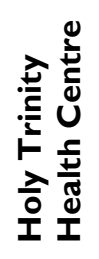 & 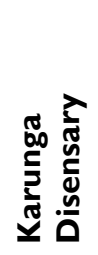 & 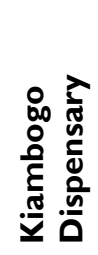 & 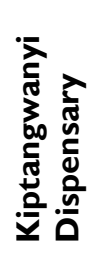 & 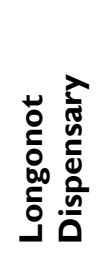 & 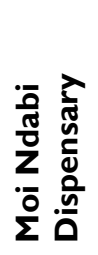 & 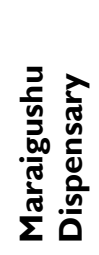 & 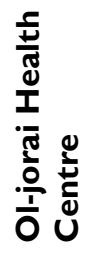 \\
\hline \multicolumn{11}{|l|}{$\begin{array}{l}\text { Nurse/clinical officer is present at facility } \\
24 \text { hours per day. }\end{array}$} \\
\hline $\begin{array}{l}\text { Nurse/clinical officer is available on call } \\
\text { at all times after hours. }\end{array}$ & & & $\sqrt{ }$ & $\sqrt{ }$ & $\sqrt{ }$ & $\sqrt{ }$ & & $\sqrt{ }$ & $\sqrt{ }$ & $\sqrt{ }$ \\
\hline Facility has staff shortages in FP services. & & $\sqrt{ }$ & $\sqrt{ }$ & $\sqrt{ }$ & $\sqrt{ }$ & & $\sqrt{ }$ & $\sqrt{ }$ & & $\sqrt{ }$ \\
\hline Speculum is available. & $\sqrt{ }$ & $\sqrt{ }$ & & $\sqrt{ }$ & $\sqrt{ }$ & $\sqrt{ }$ & $\sqrt{ }$ & $\sqrt{ }$ & $\sqrt{ }$ & $\sqrt{ }$ \\
\hline Piped running water is available. & & & $\sqrt{ }$ & & & $\sqrt{ }$ & $\sqrt{ }$ & & & $\sqrt{ }$ \\
\hline Electricity is available. & & $\sqrt{ }$ & $\sqrt{ }$ & $\sqrt{ }$ & $\sqrt{ }$ & $\sqrt{ }$ & & & $\sqrt{ }$ & \\
\hline Facilities are clean. & $\sqrt{ }$ & $\sqrt{ }$ & $\sqrt{ }$ & $\sqrt{ }$ & $\sqrt{ }$ & $\sqrt{ }$ & $\sqrt{ }$ & $\sqrt{ }$ & $\sqrt{ }$ & $\sqrt{ }$ \\
\hline $\begin{array}{l}\text { Examination room with a barrier or a } \\
\text { private examination room is available. }\end{array}$ & $\begin{array}{l}\sqrt{ } \\
(\mathrm{P})\end{array}$ & $\sqrt{ }$ & $\sqrt{ }$ & $\sqrt{ }$ & $\sqrt{ }$ & $\begin{array}{l}\sqrt{ } \\
(\mathrm{P})\end{array}$ & $\begin{array}{l}\sqrt{ } \\
(\mathrm{P})\end{array}$ & $\sqrt{ }$ & $\begin{array}{l}\sqrt{ } \\
(\mathrm{P})\end{array}$ & $\sqrt{ }$ \\
\hline $\begin{array}{l}\text { Spotlight source is available } \\
\text { (flashlight/examination light). }\end{array}$ & & & $\sqrt{ }$ & & & & & & & \\
\hline $\begin{array}{l}\text { Examination couch available for } \\
\text { gynecological exam. }\end{array}$ & & $\sqrt{ }$ & $\sqrt{ }$ & & & & & & & \\
\hline Main FP methods are available. & $\begin{array}{l}\mathrm{OC} \\
\mathrm{HI}\end{array}$ & $\begin{array}{l}\text { OC, } \\
\text { EC, } \\
\text { HI, } \\
\text { IUD, } \\
\text { MC, } \\
\text { FA }\end{array}$ & FA & $\begin{array}{l}\text { OC, } \\
\text { EC, } \\
\text { HI, } \\
\text { MC, } \\
\text { FC }\end{array}$ & $\begin{array}{l}\mathrm{OC}, \\
\mathrm{EC}, \\
\mathrm{HI}\end{array}$ & $\begin{array}{l}\mathrm{OC}, \\
\mathrm{EC}, \\
\mathrm{HI}\end{array}$ & $\begin{array}{l}\text { OC, } \\
\text { EC, } \\
\text { HI, } \\
\text { MC, } \\
\text { FC, } \\
\text { FA, } \\
\text { LAM }\end{array}$ & $\begin{array}{l}\text { OC, } \\
\mathrm{EC}, \\
\mathrm{HI}, \\
\mathrm{MC}, \\
\mathrm{FC}, \\
\mathrm{FA}\end{array}$ & $\begin{array}{l}\mathrm{OC}, \\
\mathrm{EC}, \\
\mathrm{MC}, \\
\mathrm{FA}\end{array}$ & $\begin{array}{l}\text { OC, } \\
\mathrm{EC}, \\
\mathrm{Hl}, \\
\mathrm{MC}, \\
\mathrm{FC}\end{array}$ \\
\hline
\end{tabular}

Note: $\mathrm{P}=$ private room; $\mathrm{OC}=$ oral contraceptives; $\mathrm{EC}=$ emergency contraception; $\mathrm{HI}=$ hormonal injectables; IUD=intrauterine

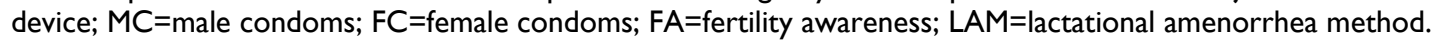

In regard to the general infrastructure of these facilities, the inventory showed that all had clean facilities and six out of 10 had electricity. Six out of 10 did not have piped running water, although water was available.

In terms of equipment, items required for gynecological examinations, such as speculums, are generally available, except at Holy Trinity Health Center. Yet, Holy Trinity Health Center was the only facility to have a spotlight source (including a flashlight or examination light). Holy Trinity Health Center and Eburu Dispensary were the only facilities to have an examination couch for gynecological exams.

Except for Holy Trinity Health Center, where only fertility awareness methods of family planning are provided, the facilities generally make the pill, the emergency contraceptive pill, 
and injectables available. The IUD was available only at Eburu Dispensary, and six of the 10 facilities offered the male condom.

Four of the facilities had private rooms for examining clients, while the rest had rooms that used a separating barrier to protect patients' privacy.

In summary, all of the health facilities could feasibly provide PAC services with some strengthening, particularly in the actual training of staff in the provision of these services.

\section{Description of Study Participants}

Table 5 confirms the close comparability of the intervention and control sites as far as key demographics are concerned. There were no significant differences between women in the sample from the intervention and control areas in terms of age (about $50 \%$ of the sample in both groups were between 20 and 29), education (mostly primary level), marital status, and religious affiliation. In regard to occupation, about half of respondents in the intervention and control sites (47\% and 55\%, respectively) were engaged in unskilled manual labor. The partners of the majority of respondents in both sites were also most likely to be engaged in unskilled manual labor (35\% and 40\%, respectively).

Table 5: Respondent and partner demographics

\begin{tabular}{|c|c|c|c|c|}
\hline \multirow[b]{2}{*}{ Demographic measure } & \multicolumn{2}{|c|}{ Intervention } & \multicolumn{2}{|c|}{ Control } \\
\hline & $\mathbf{N}$ & $\%$ & $\mathbf{N}$ & $\%$ \\
\hline Aged 20-29 & 401 & 45.3 & 192 & 50.5 \\
\hline$\%$ whose highest level of education is primary school & 400 & 74.8 & 192 & 78.1 \\
\hline$\%$ married & 401 & 79.8 & 192 & 81.3 \\
\hline \% Catholic & 401 & 15.2 & 191 & 19.4 \\
\hline \%Protestant/other Christian & 401 & 78.3 & 191 & 70.2 \\
\hline $\begin{array}{l}\text { \% employed (unskilled manual/domestic services/ } \\
\text { agriculture) }\end{array}$ & 164 & 47.0 & 87 & 55.2 \\
\hline $\begin{array}{l}\% \text { whose husband is self-employed (formal sector/ formal } \\
\text { trading) }\end{array}$ & 319 & 16.3 & 156 & |4.1 \\
\hline$\%$ whose husband is employed in skilled manual labor & 319 & 6.9 & 156 & 9.6 \\
\hline $\begin{array}{l}\% \text { whose husband is employed in unskilled manual } \\
\text { labor/domestic services }\end{array}$ & 319 & 35.1 & 156 & 39.7 \\
\hline
\end{tabular}

\section{Pregnancy and Childbearing}

To determine the extent of the burden of pregnancy complications within the evaluation areas, respondents were asked whether they had ever had a miscarriage, whether they had been pregnant in the last year, and, if so, what the outcome of that pregnancy was. As Table 6 (page 10) indicates, $11 \%$ of respondents in the intervention area had ever experienced a pregnancy that did not come to term, while $14 \%$ of respondents in the control areas had had the same experience. 
Approximately one-third of respondents in both the intervention and the control sites were pregnant in the last year. Of these, $4 \%$ in the intervention site reported having a miscarriage, compared with more than twice this proportion $(10 \%)$ in the control areas.

Table 6: Measures of pregnancy and childbearing in study areas

\begin{tabular}{|l|c|c|c|c|c|c|}
\hline \multirow{2}{*}{} & \multicolumn{2}{|c|}{ Intervention } & \multicolumn{2}{|c|}{ Control } & \multicolumn{2}{c|}{ Total } \\
\cline { 2 - 7 } & $\mathbf{N}$ & $\%$ & $\mathbf{N}$ & $\%$ & $\mathbf{N}$ & $\%$ \\
\hline Ever had a pregnancy that did not come to term & 370 & 11.1 & 178 & 14.0 & 548 & 12.0 \\
\hline Was pregnant in the past one year & 356 & 29.8 & 173 & 34.1 & 529 & 31.2 \\
\hline Had a miscarriage in the past one year & 95 & 4.2 & 58 & 10.3 & 153 & 6.5 \\
\hline
\end{tabular}

\section{Family Planning Knowledge}

Awareness creation around family planning is a key PAC strategy aimed at preventing unintended pregnancies, and, therefore, potential pregnancy complications. Though not necessarily a panacea for behavior change, knowledge of family planning methods can prompt use and can help women make informed decisions as they protect themselves from unintended pregnancy and sexually transmitted infections (which can lead to bleeding in the first half of pregnancy or other pregnancy complications). All participants were asked whether they had heard of any methods to delay or prevent pregnancy. Out of 593 respondents, most (93\% in the intervention site and $95 \%$ in the control area) had heard of a family planning method (Table 7, page 11), with the best-known methods being the pill ( $93 \%$ in both groups), the hormonal injection (88\% in the intervention group; $90 \%$ in the control group), and the IUD (49\% in the intervention group; $55 \%$ in the control group). Knowledge levels in regard to the condom and implants, respectively, were lower, at $33 \%$ and $30 \%$, respectively, in the intervention area and 34\% for both methods in the control area. Although there was low knowledge of implants in particular, the high level of knowledge about the IUD could potentially be used as an entry point to increase awareness around long-acting and permanent methods of family planning.

Government health facilities were the primary channel through which the majority of participants in the intervention and control sites (81\% and $75 \%$, respectively) had been exposed to information on family planning methods (Table 8, page 11). The radio, relatives/friends, and community members (in that order) were the other main avenues through which this kind of information was received by participants in both sites. 
Table 7: Family planning knowledge

\begin{tabular}{|c|c|c|c|c|c|c|}
\hline & \multicolumn{2}{|c|}{ Intervention } & \multicolumn{2}{|c|}{ Control } & \multicolumn{2}{|c|}{ Total } \\
\hline & $\mathbf{N}$ & $\%$ & $\mathbf{N}$ & $\%$ & $\mathbf{N}$ & $\%$ \\
\hline $\begin{array}{l}\% \text { who ever heard of methods to } \\
\text { delay or prevent pregnancy }\end{array}$ & 401 & 92.5 & 192 & 94.8 & 593 & 93.3 \\
\hline \multicolumn{7}{|l|}{$\%$ who are aware of: } \\
\hline Pill & 371 & 93.2 & 182 & 93.4 & 553 & 93.3 \\
\hline Injectable & 371 & 88.1 & 182 & 90.1 & 553 & 88.8 \\
\hline IUD & 371 & 49.1 & 182 & 55.0 & 553 & 51.0 \\
\hline Condom & 371 & 32.6 & 182 & 34.1 & 553 & 33.1 \\
\hline Hormonal implants & 371 & 29.9 & 182 & 33.5 & 553 & 31.1 \\
\hline Female sterilization & 371 & 14.8 & 182 & 14.3 & 553 & 14.7 \\
\hline Standard days method & 371 & 12.4 & 182 & 14.8 & 553 & 13.2 \\
\hline Fertility awareness methods & 371 & 6.5 & 182 & 4.4 & 553 & 5.8 \\
\hline Male sterilization & 371 & 4.0 & 182 & 0.6 & 553 & 2.9 \\
\hline Withdrawal & 371 & 2.4 & 182 & 2.8 & 553 & 2.5 \\
\hline Emergency contraception & 371 & 3.5 & 182 & 1.1 & 553 & 2.7 \\
\hline $\begin{array}{l}\text { Lactational amenorrhea } \\
\text { method }\end{array}$ & 371 & 2.7 & 182 & 1.1 & 553 & 2.2 \\
\hline Others & 371 & 2.9 & 182 & 1.7 & 553 & 2.5 \\
\hline
\end{tabular}

Table 8: Source of exposure (heard/seen/read) to information on family planning methods

\begin{tabular}{|l|c|c|c|}
\hline & $\begin{array}{c}\text { Intervention } \\
(\mathbf{N = 3 7})\end{array}$ & $\begin{array}{c}\text { Control } \\
(\mathbf{N}=\mathbf{1 8 2})\end{array}$ & $\begin{array}{c}\text { Total } \\
\mathbf{( N = 5 5 3 )}\end{array}$ \\
\cline { 2 - 4 } & $\%$ & $\%$ & $\%$ \\
\hline Government health facility & $81 . \mathrm{T}$ & 74.7 & 79.0 \\
\hline Private health facility & 7.6 & 13.7 & 9.6 \\
\hline Relative/friend & 27.0 & 31.9 & 28.6 \\
\hline Radio/TV & 30.7 & 31.9 & 31.1 \\
\hline Community member & 22.6 & 23.1 & 22.8 \\
\hline
\end{tabular}

\section{Family Planning Discussion and Use}

The positive impact of couple communication in regard to family planning on actual family planning use is well-documented. The importance of male involvement in family planning has also been increasingly emphasized in family planning programming. Respondents were therefore asked whether they had ever discussed with their partners using/doing something to delay or prevent pregnancy. About the same proportion of women in both study sites $57 \%$ in 
the intervention group; $60 \%$ in the control group) had held such discussions with their partners. Of these, around a quarter of respondents reported that their partners did not want any more children (27\% in the intervention site and $23 \%$ in the control area) (Table 9).

Table 9: Partner's desire for a (another) child

\begin{tabular}{|l|c|c|c|}
\hline \multirow{2}{*}{} & $\begin{array}{c}\text { Intervention } \\
\mathbf{( N = 3 9 4 )}\end{array}$ & $\begin{array}{c}\text { Control } \\
\mathbf{( N = 1 8 9 )}\end{array}$ & $\begin{array}{c}\text { Total } \\
(\mathbf{N}=583)\end{array}$ \\
\cline { 2 - 4 } & $\%$ & $\%$ & $\%$ \\
\hline Husband does not want a (another) child & 26.9 & 23.3 & 25.7 \\
\hline Husband wants a (another) child in: & 7.1 & 3.7 & 6.0 \\
\hline I year or less/as soon as possible & 5.3 & 2.1 & 4.3 \\
\hline Less than 2 years (in 13-23 months) & 9.4 & 11.1 & 9.9 \\
\hline 2-5 years & 7.9 & 12.7 & 9.4 \\
\hline More than 5 years & 14.0 & 19.0 & 15.6 \\
\hline Don't know & 29.4 & 28.0 & 29.0 \\
\hline Not applicable & & & \\
\hline
\end{tabular}

Near equal proportions of women (more than 60\% in intervention and control areas alike) reported that their partners approve of their use of a family planning method (Table 10). Women's personal approval of family planning use was slightly higher, at more than $70 \%$ in intervention and control groups.

Table 10: Partner approval of family planning

\begin{tabular}{|l|c|c|c|c|c|c|}
\hline \multirow{2}{*}{} & \multicolumn{2}{|c|}{ Intervention } & \multicolumn{2}{c|}{ Control } & \multicolumn{2}{c|}{ Total } \\
\cline { 2 - 7 } & $\mathbf{N}$ & $\%$ & $\mathbf{N}$ & $\%$ & $\mathbf{N}$ & $\%$ \\
\hline $\begin{array}{l}\text { Respondent reports partner } \\
\text { approval of family planning }\end{array}$ & 310 & 66.1 & 153 & 61.4 & 463 & 64.6 \\
\hline $\begin{array}{l}\text { Respondent approves of family } \\
\text { planning }\end{array}$ & 370 & 73.5 & 182 & 70.9 & 552 & 72.6 \\
\hline
\end{tabular}

Nearly half of all respondents said they would like to have another child in the future (44\% intervention; 47\% control) (Table 11, page 13); however, the majority would prefer to get pregnant again within the next $2-5$ years $(27 \%$ and $29 \%$ in intervention and control areas, respectively) or in more than 5 years from the time of interview (20\% intervention and $26 \%$ control). A significant proportion of respondents were undecided about when they wanted to conceive again (21\% intervention; $27 \%$ control). 
Table I I: Respondent's desire for a (another) child

\begin{tabular}{|l|r|r|r|r|r|r|r|}
\hline & \multicolumn{2}{|c|}{ Intervention } & \multicolumn{2}{|c|}{ Control } & \multicolumn{2}{|c|}{ Total } \\
\cline { 2 - 8 } & $\mathbf{N}$ & $\%$ & $\mathbf{N}$ & $\%$ & $\mathbf{N}$ & $\%$ \\
\hline $\begin{array}{l}\text { \% of respondents who would like to have a } \\
\text { (another) child }\end{array}$ & 398 & 43.5 & 191 & 46.6 & 589 & 44.5 \\
\hline $\begin{array}{l}\text { If respondent does want a (another) child, \% } \\
\text { reporting when she would like to become pregnant: }\end{array}$ & \multicolumn{1}{|l|}{} & & & & \\
\hline I year or less/as soon as possible & 173 & 14.7 & 89 & 7.8 & 262 & 12.2 \\
\hline Less than 2 years (in I3-23 months) & 173 & 14.7 & 89 & 9.7 & 262 & 12.9 \\
\hline 2-5 years & 173 & 27.2 & 89 & 29.1 & 262 & 27.6 \\
\hline More than 5 years & 173 & 20.1 & 89 & 26.2 & 262 & 22.3 \\
\hline Other & 173 & 2.7 & 89 & 0.0 & 262 & 1.7 \\
\hline Don't know & 173 & 20.7 & 89 & 27.2 & 262 & 23.0 \\
\hline
\end{tabular}

Given knowledge levels on family planning in the study communities and the respondents' fertility intentions, it is important to explore actual family planning use among the participants. Approximately the same proportion of women in the intervention (47\%) and control $(46 \%)$ areas reported using family planning methods currently (Table 12), with the injectable being the most commonly used method in both areas. While the injection is used by more than half of those relying on a method in the intervention and control sites, the pill $(10 \%$ intervention; $13 \%$ control) and the standard days method (7\% intervention; $10 \%$ control) are the second and third most commonly used methods, respectively, in both sites.

Table I 2: Current use of family planning

\begin{tabular}{|l|c|c|c|c|c|c|c|}
\hline \multirow{2}{*}{} & \multicolumn{2}{|c|}{ Intervention } & \multicolumn{2}{c|}{ Control } & \multicolumn{3}{c|}{ Total } \\
\cline { 2 - 7 } & $\mathbf{N}$ & $\%$ & $\mathbf{N}$ & $\%$ & $\mathbf{N}$ & $\%$ \\
\hline \% currently using family planning & 343 & 46.9 & 172 & 45.9 & 515 & 46.6 \\
\hline $\begin{array}{l}\text { \% distribution of family planning } \\
\text { methods currently used: }\end{array}$ & \multicolumn{5}{|l|}{} \\
\hline Injectable & 160 & 58.8 & 77 & 57.1 & 237 & 58.2 \\
\hline Pill & 160 & 10.0 & 77 & 18.2 & 237 & 12.7 \\
\hline Standard days method & 160 & 6.9 & 77 & 10.4 & 237 & 8.0 \\
\hline Female sterilization & 160 & 6.3 & 77 & 3.9 & 237 & 5.5 \\
\hline IUD (Copper-T) & 160 & 5.6 & 77 & 2.6 & 237 & 4.6 \\
\hline Fertility awareness method & 160 & 4.4 & 77 & 2.6 & 237 & 3.8 \\
\hline Condoms & 160 & 3.8 & 77 & 2.6 & 237 & 3.4 \\
\hline Lactational amenorrhea & 160 & 0.0 & 77 & 2.6 & 237 & 0.8 \\
\hline Implants & 160 & 2.5 & 77 & 0.0 & 237 & 1.7 \\
\hline Emergency contraception & 160 & 0.6 & 77 & 0.0 & 237 & 0.4 \\
\hline Other & 160 & 1.3 & 77 & 0.0 & 237 & 0.8 \\
\hline
\end{tabular}


Not being married, breastfeeding, and fearing side effects (in that order) emerged as the top three reasons cited by respondents who were not currently practicing contraception as the main barriers to their use of family planning in both intervention and control groups (Table 13). Of those not currently using a family planning method, nearly three in five $(58 \%$ intervention; $59 \%$ control) did not want to have another child in the future.

Table 13: Main reasons for not using family planning

\begin{tabular}{|l|c|r|r|}
\hline & $\begin{array}{c}\text { Intervention } \\
\mathbf{( N = 1 8 2 )}\end{array}$ & $\begin{array}{c}\text { Control } \\
\mathbf{( N = 9 2 )}\end{array}$ & $\begin{array}{c}\text { Total } \\
\mathbf{( N = 2 7 4 )}\end{array}$ \\
\cline { 2 - 4 } & \multicolumn{1}{|c|}{$\begin{array}{c}\text { \% } \\
\text { \% }\end{array}$} & 20.7 & 2 I.9 \\
\hline Is not married & 22.5 & 17.4 & 17.5 \\
\hline Is breastfeeding & 17.6 & 13.0 & 12.0 \\
\hline Fears side effects & 11.5 & 12.0 & 9.5 \\
\hline Is not having sex & 8.2 & 7.6 & 6.6 \\
\hline Respondent is opposed & 6.0 & 8.7 & 5.8 \\
\hline Husband/partner is opposed & 4.4 & 5.4 & 5.1 \\
\hline Interferes with body's natural processes & 5.0 & 2.2 & 2.9 \\
\hline Having infrequent sex & 3.3 & 3.3 & 4.7 \\
\hline Religious prohibition & 5.5 & 5.4 & 3.3 \\
\hline Is subfecund/infecund & 2.2 & 0.0 & 4.4 \\
\hline Is menopausal/had hysterectomy & 6.6 & 0.0 & 0.4 \\
\hline Is fatalistic & 0.6 & 1.1 & 1.8 \\
\hline Family planning is inconvenient to use & 2.2 & 2.2 & 0.7 \\
\hline Knows no source & 0.0 & 7.6 & 5.5 \\
\hline Doesn't know & 4.4 & & \\
\hline
\end{tabular}

\section{Knowledge and Utilization of Health Services}

Access to health services, including family planning and PAC, can be hampered by a lack of awareness of sources of care. Respondents were therefore asked questions to assess their knowledge of the availability of a range of reproductive health services, including family planning, ANC, delivery care, and PAC-related services.

Most respondents indicated that the majority of people in their communities get their family planning methods from government health facilities (98\% intervention; 94\% control) (Table 14).

Table 14: Perceived access points for family planning methods among community members

\begin{tabular}{|l|c|c|c|}
\hline & $\begin{array}{c}\text { Intervention } \\
(\mathbf{N = 3 7})\end{array}$ & $\begin{array}{c}\text { Control } \\
\mathbf{( N = 1 8 2})\end{array}$ & $\begin{array}{c}\text { Total } \\
\mathbf{( N = 5 5 3 )}\end{array}$ \\
\cline { 2 - 4 } & $\%$ & $\%$ & $\%$ \\
\hline Government health facility & 97.6 & 94.0 & 96.4 \\
\hline Private health facility & 15.6 & 30.2 & 20.4 \\
\hline Pharmacy/chemist & 4.9 & 1.7 & 3.8 \\
\hline Traditional birth attendant (TBA) & 0.0 & 0.6 & 0.2 \\
\hline Herbalist & 3.8 & 4.4 & 4.0 \\
\hline Other & 0.5 & 3.9 & 1.6 \\
\hline
\end{tabular}


As their point of access to ANC, the majority of women in intervention and control sites, respectively, cited either government hospitals ( $41 \%$ and $53 \%$, respectively), government health centers $(50 \%$ and $39 \%$, respectively), or dispensaries ( $44 \%$ and $57 \%$, respectively) (Table 15).

Table 15: Perceived access points for ANC among community members

\begin{tabular}{|l|c|c|c|}
\hline & $\begin{array}{c}\text { Intervention } \\
(\mathbf{N}=\mathbf{4 0 I})\end{array}$ & $\begin{array}{c}\text { Control } \\
(\mathbf{N = 1 9 2})\end{array}$ & $\begin{array}{c}\text { Total } \\
(\mathbf{N = 5 9 3 )}\end{array}$ \\
\cline { 2 - 4 } & $\%$ & $\%$ & $\%$ \\
\hline Government hospital/clinic & 41.4 & 52.6 & 45.0 \\
\hline Government health center & 50.4 & 39.1 & 46.7 \\
\hline Dispensary & 44.4 & 57.3 & 48.6 \\
\hline Private hospital/clinic & 8.5 & 10.9 & 9.3 \\
\hline TBA's home & 0.0 & 3.1 & 1.0 \\
\hline Nowhere/they do not go & 5.2 & 4.2 & 4.9 \\
\hline Other & 0.5 & 0.5 & 0.5 \\
\hline
\end{tabular}

In regard to delivery, while government health facilities seem to be patronized by study respondents, the community perception is that a significant proportion of women still deliver at home $(33 \%$ in the intervention areas and $45 \%$ in control sites) (Table 16).

Table 16: Perceived access points for delivery care among community members

\begin{tabular}{|l|c|c|c|}
\hline & $\begin{array}{c}\text { Intervention } \\
(\mathbf{N = 4 0 I )}\end{array}$ & $\begin{array}{c}\text { Control } \\
\mathbf{( N = 1 9 2 )}\end{array}$ & $\begin{array}{c}\text { Total } \\
\mathbf{( N = 5 9 3 )}\end{array}$ \\
\cline { 2 - 4 } & $\%$ & $\%$ & $\%$ \\
\hline Government hospital/clinic & 50.9 & 63.5 & 55.0 \\
\hline Government health center & 50.6 & 27.6 & 43.2 \\
\hline Dispensary & 31.7 & 26.0 & 29.8 \\
\hline Private hospital/clinic & 10.2 & 9.4 & 10.0 \\
\hline TBA's home & 0.8 & 4.2 & 1.9 \\
\hline At home & 33.2 & 44.8 & 36.9 \\
\hline Other & 0.5 & 0.5 & 0.5 \\
\hline
\end{tabular}

A key concern of public health interventionists is that knowledge of the availability of health services does not necessarily translate to actual utilization. Of those in the study sample who had been pregnant during the past year, $85 \%$ in the intervention area and $79 \%$ in the control area had visited a government health facility for ANC. A significant proportion of women in both the intervention and control groups made their first ANC visit in the fifth or sixth month of pregnancy (Table 17, page 16). However, 9\% of women in the intervention group and $20 \%$ of women in the control group made their first ANC visit in the third month of pregnancy, while $21 \%$ in the intervention site and $10 \%$ in the control site did so in the fourth month. Of those who attended ANC, 36\% in the intervention area made four or more visits, compared with $57 \%$ in the control area $(\mathrm{p}<.05)$. 
Table I7: Month of gestation at which respondents made their first ANC visit during their last or current pregnancy

\begin{tabular}{|l|c|c|c|}
\hline Month of gestation & $\begin{array}{c}\text { Intervention } \\
(\mathbf{N}=96)\end{array}$ & $\begin{array}{c}\text { Control } \\
\mathbf{( N = 5 0 )}\end{array}$ & $\begin{array}{c}\text { Total } \\
\mathbf{( N = 1 4 6 )}\end{array}$ \\
\hline & $\%$ & $\%$ & $\%$ \\
\hline 0 & 0.0 & 2.0 & 0.7 \\
\hline 1 & 1.0 & 0.0 & 0.7 \\
\hline 2 & 3.1 & 6.0 & 4.1 \\
\hline 3 & 9.4 & 20.0 & 13.0 \\
\hline 4 & 20.8 & 10.0 & 17.1 \\
\hline 5 & 20.8 & 30.0 & 24.0 \\
\hline 6 & 28.1 & 18.0 & 24.7 \\
\hline 7 & 13.5 & 14.0 & 13.7 \\
\hline 8 & 3.1 & 0.0 & 2.1 \\
\hline
\end{tabular}

In regard to delivery, $55 \%$ and $37 \%$ of women in the intervention and control areas, respectively, received skilled attendance the last time they had a child. Nearly one-third of women delivered at home while attended by a relative or friend, a proportion that was comparable across sites (32\% and 35\%) (Table 18). However, the proportion of women who reported delivering by themselves was twice as great in the control area $(10 \%)$ as in the intervention site $(5 \%)$.

Table I 8: Attendant at last delivery

\begin{tabular}{|l|c|c|c|}
\hline & $\begin{array}{c}\text { Intervention } \\
(\mathbf{N = 8 5})\end{array}$ & $\begin{array}{c}\text { Control } \\
\mathbf{( N = 5 ~ I ) ~}\end{array}$ & $\begin{array}{c}\text { Total } \\
(\mathbf{N}=136)\end{array}$ \\
\cline { 2 - 4 } & $\%$ & $\%$ & $\%$ \\
\hline Doctor & 12.9 & 3.9 & 9.6 \\
\hline Nurse/midwife & 42.4 & 33.3 & 39.0 \\
\hline TBA & 7.1 & 9.8 & 8.1 \\
\hline Relative/friend & 31.8 & 35.3 & 33.1 \\
\hline No one & 4.7 & 9.8 & 6.6 \\
\hline Other* & 1.2 & 7.8 & 3.7 \\
\hline
\end{tabular}

$*_{p}<0.05$

\section{Pregnancy Experiences and Complications}

Knowledge of danger signs in pregnancy is integral to addressing pregnancy complications on the part of women. Respondents were asked to list the danger signs in pregnancy that they were aware of. Bleeding-related signs, severe abdominal pain, feeling ill/weakness, and severe/persistent nausea/vomiting were cited the most by respondents (Table 19, page 17). 
Table 19: Percentage of respondents knowing various danger signs or complications in early pregnancy

\begin{tabular}{|l|r|r|r|}
\hline & $\begin{array}{c}\text { Intervention } \\
\mathbf{( N = 3 8 8 )}\end{array}$ & $\begin{array}{c}\text { Control } \\
\mathbf{( N = 1 8 6 )}\end{array}$ & $\begin{array}{c}\text { Total } \\
\mathbf{( N = 5 7 4 )}\end{array}$ \\
\cline { 2 - 4 } & $\%$ & $\%$ & $\%$ \\
\hline Increased bleeding & 32.2 & 43.0 & 35.7 \\
\hline Bleeding heavier than a normal period & 13.4 & 21.0 & 15.9 \\
\hline Continued bleeding for two weeks & 2.8 & 1.6 & 2.4 \\
\hline Severe abdominal pain & 38.4 & 44.6 & 40.4 \\
\hline Fever & 7.2 & 8.1 & 7.5 \\
\hline Chills & 6.2 & 7.0 & 6.4 \\
\hline Foul-smelling vaginal discharge & 3.9 & 6.5 & 4.7 \\
\hline Muscle aches & 13.4 & 10.2 & 12.4 \\
\hline Tenderness to pressure in abdomen & 4.6 & 3.2 & 4.2 \\
\hline Dizziness or fainting & 15.2 & 20.4 & 16.9 \\
\hline Feeling ill, weakness & 39.4 & 38.7 & 39.2 \\
\hline Persistent nausea or vomiting & 42.5 & 42.5 & 42.5 \\
\hline Severe and constant headache & 9.3 & 5.9 & 8.2 \\
\hline Other & 16.5 & 18.3 & 17.1 \\
\hline
\end{tabular}

Respondents were also asked about their own personal experiences with pregnancy complications-specifically, with bleeding in the first few months of pregnancy. Eleven percent of all respondents had ever experienced bleeding in the first few months of pregnancy (10\% control; $13 \%$ intervention) (Table 20$)$. Of these, nearly one-third of all respondents $(30 \%)$ in the intervention and control sites combined (35\% intervention, $21 \%$ control) did not seek care for this condition.

Table 20: Percentage of respondents who experienced bleeding in the first few months of pregnancy and percentage who sought care

\begin{tabular}{|l|c|c|c|c|c|c|}
\hline \multirow{2}{*}{} & \multicolumn{2}{|c|}{ Intervention } & \multicolumn{2}{|c|}{ Control } & \multicolumn{2}{c|}{ Total } \\
\cline { 2 - 6 } & $\mathbf{N}$ & $\%$ & $\mathbf{N}$ & $\%$ & $\mathbf{N}$ & $\%$ \\
\hline $\begin{array}{l}\text { Ever experienced bleeding in first few months of } \\
\text { pregnancy }\end{array}$ & 378 & 9.8 & 180 & 13.3 & 558 & 10.9 \\
\hline $\begin{array}{l}\text { Did not seek care for bleeding and other } \\
\text { complications }\end{array}$ & 37 & 35.1 & 24 & 20.8 & 61 & 29.5 \\
\hline
\end{tabular}

As with other health services, overall, the majority of respondents were aware of government health facilities as sites where care for bleeding in the first few months of pregnancy could be sought (Table 21, page 18). However, while none of the respondents in the intervention sites reported that they sought care specifically at a government dispensary, dispensaries were the selected care site for bleeding in the first few months of pregnancy for $47 \%$ of respondents in the control areas (Table 22, page 18). Furthermore, in the intervention sites, $30 \%$ of respondents sought care within private health facilities, compared with none in the control areas. This is despite the fact that both intervention and control sites are home to one private health facility and an almost similar number of government dispensaries (four in the 
intervention area and three in the control area). Additionally, there is one government health center in the intervention site, but none in the control area.

Table 2 I: Percentage knowing where to access care in case of bleeding in early pregnancy

\begin{tabular}{|l|c|c|c|}
\hline & $\begin{array}{c}\text { Intervention } \\
\mathbf{( N = 4 0 ~ I ) ~}\end{array}$ & $\begin{array}{c}\text { Control } \\
\mathbf{( N = 1 9 2 )}\end{array}$ & $\begin{array}{c}\text { Total } \\
\mathbf{( N = 5 9 3 )}\end{array}$ \\
\cline { 2 - 4 } & $\%$ & $\%$ & $\%$ \\
\hline Government hospital/clinic & 51.6 & 64.1 & 55.6 \\
\hline Government health center & 54.1 & 34.9 & 47.9 \\
\hline Dispensary & 40.1 & 46.9 & 42.3 \\
\hline Private hospital/clinic & 14.5 & 14.6 & 14.5 \\
\hline TBA & 1.3 & 0.0 & 0.8 \\
\hline CHW & 0.3 & 0.5 & 0.3 \\
\hline Herbalist & 1.3 & 3.1 & 1.9 \\
\hline Friend & 1.5 & 1.6 & 1.5 \\
\hline Other & 0.3 & 1.6 & 0.7 \\
\hline
\end{tabular}

Table 22: Place where care was sought for bleeding in early pregnancy

\begin{tabular}{|l|c|c|c|}
\hline & $\begin{array}{c}\text { Intervention } \\
(\mathbf{N = 2 3 )}\end{array}$ & $\begin{array}{c}\text { Control } \\
\mathbf{( N = 1 9 )}\end{array}$ & $\begin{array}{c}\text { Total } \\
(\mathbf{N}=\mathbf{4 2})\end{array}$ \\
\cline { 2 - 4 } & $\%$ & $\%$ & $\%$ \\
\hline Government hospital/clinic & 52.2 & 47.4 & 50.0 \\
\hline Government health center & 26.1 & 0.0 & 14.3 \\
\hline Dispensary & 0.0 & 47.4 & 21.4 \\
\hline Private hospital/clinic & 30.4 & 0.0 & 16.7 \\
\hline
\end{tabular}

A considerable percentage of participants sought services for bleeding in the first half of pregnancy outside their communities and at distances that required the use of transportation (63\% in the intervention areas; $42 \%$ in the control areas) (Table 23). Only $13 \%$ of respondents in the intervention site sought services within their own communities and within walking distance, compared with $26 \%$ in the control site.

Table 23: Mode of transportation to place where care was sought for bleeding in early pregnancy

\begin{tabular}{|l|c|c|c|}
\hline & $\begin{array}{c}\text { Intervention } \\
(\mathbf{N = 2 4 )}\end{array}$ & $\begin{array}{c}\text { Control } \\
\mathbf{( N = 1 9 )}\end{array}$ & $\begin{array}{c}\text { Total } \\
\mathbf{( N = 4 3 )}\end{array}$ \\
\cline { 2 - 4 } & $\%$ & $\%$ & $\%$ \\
\hline Within community, at walking distance & 12.5 & 26.3 & 18.6 \\
\hline Within community, but need transportation & 20.8 & 31.6 & 25.6 \\
\hline Outside community, at walking distance & 4.2 & 0.0 & 2.3 \\
\hline Outside community, need transportation & 62.5 & 42.1 & 53.5 \\
\hline
\end{tabular}


The largest proportion of respondents in both the intervention and control sites travelled one to two hours to obtain services for bleeding in the first half of pregnancy $(65 \%$ in the intervention area; $37 \%$ in the control area), with about one-third spending anywhere from KSH 50-100 on transportation (31\% and 35\%, respectively) and a considerable proportion spending KSH $100-500$ on services, including drugs and supplies (60\% and $32 \%$, respectively). Women reported being supported by their partners in various ways to obtain PAC services. The main form of support in both intervention and control areas involved the provision of money to cover the cost of services (Table 24); however, partners were also noted to have played a role in accompanying respondents, giving them permission to go for health care, and providing transportation.

Table 24: Partner support for obtaining PAC services

\begin{tabular}{|l|c|c|c|}
\hline & $\begin{array}{c}\text { Intervention } \\
(\mathbf{N}=1 \mathbf{9})\end{array}$ & $\begin{array}{c}\text { Control } \\
\mathbf{( N = 1 9 )}\end{array}$ & $\begin{array}{c}\text { Total } \\
\mathbf{( N = 3 8 )}\end{array}$ \\
\cline { 2 - 4 } & $\%$ & $\%$ & $\%$ \\
\hline Gave permission to go & 47.4 & 15.8 & 31.6 \\
\hline Provided transportation & 31.6 & 21.1 & 26.3 \\
\hline Provided money & 84.2 & 68.4 & 76.3 \\
\hline Accompanied respondent & 36.8 & 52.6 & 44.7 \\
\hline Other & 10.5 & 5.3 & 7.9 \\
\hline
\end{tabular}

Half of all those in the intervention and control areas who sought services for bleeding in the first half of pregnancy did so in the company of their husband (50\% and 49\%, respectively). Of these, respondents who were accompanied by an additional individual were most likely to be in the company of a friend or neighbor $(21 \%$ and $20 \%)$, followed by being in the company of their mother ( $17 \%$ and $12 \%$ control).

For women who did not seek care for bleeding in the first few months of pregnancy, about one-third of respondents in the intervention and control sites combined did not think that this symptom during pregnancy was a serious enough problem for them to seek care or thought it was normal and thus did not see a need to seek care (Table 25). Concern about costs deterred approximately one in five respondents in both study settings combined from seeking care for the same condition.

Table 25: Reasons for not seeking care for bleeding in early pregnancy

\begin{tabular}{|l|c|c|c|}
\hline & $\begin{array}{c}\text { Intervention } \\
(\mathbf{N = 1 2 )}\end{array}$ & $\begin{array}{c}\text { Control } \\
\mathbf{( N = 4 )}\end{array}$ & $\begin{array}{c}\text { Total } \\
(\mathbf{N = 1 6 )}\end{array}$ \\
\hline Did not know where to go & $\mathrm{I}$ & 0 & $\mathrm{I}$ \\
\hline Lacked transportation & $\mathrm{I}$ & $\mathrm{I}$ & 2 \\
\hline Was afraid it would cost too much & 0 & $\mathrm{I}$ & 3 \\
\hline Husband was opposed & 4 & $\mathrm{I}$ & $\mathrm{I}$ \\
\hline Thought it was normal/not serious & $\mathrm{I}$ & 0 & $\mathrm{I}$ \\
\hline Facility is very far & $\mathrm{I}$ & 0 & $\mathrm{I}$ \\
\hline Was not sure she was pregnant & & & \\
\hline
\end{tabular}




\section{Perceptions of Quality of Care for Bleeding in the First Half of Pregnancy}

According to the International Planned Parenthood Federation, good quality health care, from the perspective of clients, has been shown to enhance both client satisfaction and utilization of services. Furthermore, it enhances job satisfaction on the part of providers, giving them an incentive to work more effectively. The combination of these in a PAC setting can lead to greater sustainability of PAC services (IPPF, 2010). To explore perceptions of quality of care among respondents who sought care for bleeding in the first half of pregnancy, interviewers posed questions to the respondents around issues such as comfort, privacy, and clarity of the information given by the provider.

Findings indicate that virtually all of the respondents who sought care at a health facility for bleeding in the first half of pregnancy were offered pain medication by their providers $(100 \%$ in the intervention areas; $95 \%$ in the control areas).

There were variations in the amount of time for which respondents in the intervention and control areas reported having to wait to see a provider when they visited a facility for treatment of bleeding in the first half of pregnancy. Some respondents in the intervention and control areas (21\% and $42 \%$, respectively) reported having to wait more than one and one-half hours (Table 26). Thirteen percent of those in the intervention area reported having to wait for one to one and a half hours to see a provider, compared to none in the control area. A number of respondents also indicated that they did not have to wait at all $(21 \%$ and $32 \%)$.

Table 26: Waiting period before being seen by provider

\begin{tabular}{|l|c|c|c|}
\hline & $\begin{array}{c}\text { Intervention } \\
\mathbf{( N = 2 4 )}\end{array}$ & $\begin{array}{c}\text { Control } \\
\mathbf{( N = 1 9 )}\end{array}$ & $\begin{array}{c}\text { Total } \\
\mathbf{( N = 4 3 )}\end{array}$ \\
\cline { 2 - 4 } & $\%$ & $\%$ & $\%$ \\
\hline More than I.5 hours & 20.8 & 42.1 & 30.2 \\
\hline I-I.5 hours & 12.5 & 0.0 & 7.0 \\
\hline 30-59 minutes & 4.2 & 0.0 & 2.3 \\
\hline I-29 minutes & 41.7 & 21.1 & 32.6 \\
\hline Did not have to wait & 20.8 & 31.6 & 25.6 \\
\hline Other & 0.0 & 5.3 & 2.3 \\
\hline
\end{tabular}

The vast majority of the participants who had sought care for bleeding in the first half of pregnancy were of the opinion that they were accorded enough privacy during their visit $(89 \%$ in the intervention areas; $88 \%$ in the control areas); that the provider's explanation of the procedure to be performed was clear $(99 \%$ and $72 \%)$; that they were treated well by the provider ( $99 \%$ and $89 \%)$; and that they were treated well by other health facility staff $(85 \%$ and $84 \%)$. Similar proportions of respondents in the intervention and control sites $(75 \%$ and $74 \%$, respectively) had recommended the health facility they sought services at to someone else.

When asked to spontaneously recall the kind of information providers gave them upon discharge, the participants were least likely to mention issues of family planning ( $4 \%$ in the intervention areas; $5 \%$ in the control areas) and return to fertility ( $8 \%$ and $5 \%$ ) (Table 27, page 21). On the other hand, information on the need to rest, the return date for a check-up, and nutrition were more likely to be mentioned without probing. 
Table 27: Information received upon discharge

\begin{tabular}{|l|c|c|c|}
\hline & $\begin{array}{c}\text { Intervention } \\
(\mathbf{N = 2 4 )}\end{array}$ & $\begin{array}{c}\text { Control } \\
(\mathbf{N = 1 9 )}\end{array}$ & $\begin{array}{c}\text { Total } \\
\mathbf{( N = 4 3 )}\end{array}$ \\
\cline { 2 - 4 } & $\%$ & $\%$ & $\%$ \\
\hline Return to fertility & 8.3 & 5.3 & 7.0 \\
\hline Family planning & 4.2 & 5.3 & 4.7 \\
\hline Nutrition & 20.8 & 15.8 & 18.6 \\
\hline The need to rest & 62.5 & 36.8 & 51.2 \\
\hline The date of return visit for check-up & 45.8 & 36.8 & 41.9 \\
\hline Self-care and danger signs & 16.7 & 31.6 & 23.3 \\
\hline Other & 0.0 & 36.8 & 16.3 \\
\hline
\end{tabular}

However, in regard to the more direct question of whether respondents adopted a family planning method prior to discharge, we looked at the experiences of the 11 women who had experienced a pregnancy loss due to complications (four from the intervention site and seven from the control area). Two of the four women at the intervention site who sought care for bleeding had a skilled health professional speak to them about family planning methods, as was the case with two of the seven women from the control areas. As these are respondent reports, it is not clear whether providers had followed a prescribed model of providing care for women reporting bleeding. Nevertheless, of those who spoke with a skilled health professional about family planning methods, one of the two women in the control areas accepted a method, while none of their peers in the intervention areas left with a method.

\section{Exposure to Community Interventions}

Community empowerment through community awareness and mobilization forms an important part of PAC programs, particularly as PAC service delivery is decentralized to lower levels of the health system (USAID, 2004). The role of CHEWs and CHWs in heightening community awareness and mobilization is therefore critical for the success and sustainability of any PAC intervention in the Kenyan context.

A series of questions on exposure to community interventions was posed to respondents to assess their level of engagement with any such interventions, and with CHEWs and CHWs, who will play an important role in RESPOND's community mobilization intervention. As expected (particularly, given that the RESPOND interventions had not begun at the time of data collection), exposure levels to community interventions in general, and to community interventions around bleeding in the first few months of pregnancy in particular, were generally low in both study areas.

About half of the respondents did not know of any CHEWs or CHWs at all $(52 \%$ in the intervention sites; $43 \%$ in the control sites) (Table 28, page 22). This was also expected, as the MOH's Community Strategy, which involves continuous engagement with CHEWs and CHWs, is still nascent. Of those that were acquainted with any CHEWs or CHWs, more participants knew of CHWs only, as opposed to CHEWs (37\% and 35\%). 
Table 28: Knowledge of CHEWs or CHWs

\begin{tabular}{|l|c|c|c|c|c|c|}
\hline \multirow{2}{*}{} & \multicolumn{2}{|c|}{ Intervention } & \multicolumn{2}{c|}{ Control } & \multicolumn{2}{c|}{ Total } \\
\cline { 2 - 7 } & $\mathbf{( N = 4 0 I )}$ & $\%$ & $\mathbf{( N = 1 9 2 )}$ & $\%$ & $\mathbf{( N = 5 9 3 )}$ & $\%$ \\
\hline Know some CHEWs only & 12 & 3.0 & 20 & 10.4 & 32 & 5.4 \\
\hline Know some CHWs only & 147 & 36.7 & 68 & 35.4 & 215 & 36.3 \\
\hline Know some CHEWs and CHWs & 33 & 8.2 & 22 & 11.5 & 55 & 9.3 \\
\hline Do not know of any CHEWs or CHWs & 209 & 52.1 & 82 & 42.7 & 291 & 49.1 \\
\hline Total & 401 & 100.0 & 192 & 100.0 & 593 & 100.0 \\
\hline
\end{tabular}

Fewer than $10 \%$ of respondents in both sites had ever participated in any meeting that was sponsored by a nongovernmental organization (NGO) or a community group and that focused on bleeding in the first half of pregnancy (Table 29). Knowledge about any information campaign in the community about health care for women experiencing this problem was negligible (2\% in the intervention area and 3\% in the control group).

Table 29: Participation in NGO/community group meetings/ activities or CHW meetings/activities focused on bleeding in the first half of pregnancy in the past year

\begin{tabular}{|l|c|c|c|c|c|c|}
\hline & Intervention & \multicolumn{2}{|c|}{ Control } & \multicolumn{2}{c|}{ Total } \\
\cline { 2 - 6 } & $\mathbf{N}$ & $\%$ & $\mathbf{N}$ & $\%$ & $\mathbf{N}$ & $\%$ \\
\hline $\begin{array}{l}\text { Have participated in the past year in any } \\
\text { NGO/community group meetings/ activities } \\
\text { focused on bleeding in the first half of } \\
\text { pregnancy }\end{array}$ & 173 & 9.3 & 89 & 7.9 & 262 & 8.8 \\
\hline $\begin{array}{l}\text { Have participated in the past year in any CHW } \\
\text { meetings/activities focused on bleeding in the } \\
\text { first half of pregnancy }\end{array}$ & $40 \mathrm{I}$ & 6.7 & 192 & 2.1 & 593 & 5.2 \\
\hline
\end{tabular}




\section{Summary of Key Messages}

The baseline evaluation yields key findings that are relevant for the intervention to be implemented. The baseline provided a general picture of community knowledge and behaviors and of the range of service options that are available. These details will be useful for honing and refining the intervention, or any specific component of the latter, such as the community action cycle. For example, given the low exposure of community residents to any type of community mobilization activity, the community action cycle for PAC may require repeated sessions so as to saturate the community. Key messages follow.

- There is a clear need for PAC services in the evaluation sites. Although women are aware of a number of danger signs in pregnancy, a significant proportion of women are not aware that bleeding in the first half of pregnancy is not normal or could signify a problem. Furthermore, approximately one-third of the women experiencing bleeding had not sought care, indicating a significant proportion of women who are unaware of the lifethreatening risks they face by not seeking care. This lack of knowledge about the danger signs of bleeding, due either to miscarriage or to unsafe abortion, merits attention and must be prioritized in the intervention.

- A significant proportion of respondents were undecided about when they wanted to conceive again (21\% in the intervention group; $27 \%$ in the control group). Working to resolve this ambiguity would be an important step, as indecision can lead to unintended pregnancy.

- Exposure to community interventions in general is low. Knowledge of CHEWs and CHWs is also low, although more respondents tended to know CHWs. Community mobilization efforts will have to be intensive in terms of inputs and will have to widely cover the intervention communities. Efforts can also be made to include men in the community action cycle, as women reported that their partners were important decision makers and supporters of their health.

- Utilization of health services during pregnancy and delivery is limited. For example, a significant proportion of women sought their first ANC check-up in the second trimester (at 5-6 months); one-third of respondents reported delivering at home attended by friends or relatives. The intervention should focus on building community awareness in regard to seeking appropriate care at relevant times over the course of pregnancy.

- Women identify and seek care at government health facilities for a range of services, including bleeding in the first half of pregnancy, PAC, ANC, delivery, and family planning. Linking communities and health services will be an important strategy to increase utilization of health services.

- While knowledge of family planning is high, actual use is significantly lower. Lack of knowledge of the range of methods available, lack of specific knowledge of individual methods, and fear of side effects are some key reasons for nonuse. Facilities serving the intervention sites should be strengthened to offer a full range of choices, including longacting methods, and referrals for permanent methods where possible, and to offer contraceptive services to all women seeking PAC. 
- In addition, the large percentage of women who are not using a family planning method but who desire to limit future births (approximately 60\% in both intervention and control areas) demonstrates significant unmet need. Women that wish to avoid pregnancies should be provided with information and methods such that they can make an informed choice. Creating dialogue about the need and availability of family planning methods should be pursued during community-level engagement, to address the barriers to use.

- The largest percentage of respondents (intervention and control) reported that their main reason for not using family planning was because they were not married. Efforts should be made to focus on these young unmarried women who are also reported to have some of the highest rates of unsafe abortion in Kenya. 


\section{References}

Curtis, C., Huber, D., and Moss-Knight, T. 2010. Postabortion family planning: Addressing the cycle of repeat unintended pregnancy and abortion. International Perspectives on Sexual and Reproductive Health 36(1):XX-XX.

International Planned Parenthood Federation (IPPF). 2010. Quality of care programme. London. Accessed at: http://www.ippf.org/en/What-we-do/Quality+of+Care+programme.htm.

Kenya Ministry of Health (KMOH). 2005. A report on performance status health management information system: 2003-2004 annual report. Nairobi.

KMOH. 2006. Taking the Kenya Essential Package for Health to the community-A strategy for the delivery of Level One services. Nairobi.

KMOH. 2008. Annual health sector status report: 2005-2007. Nairobi.

USAID. 2004. USAID postabortion care strategy paper. Washington, DC. Accessed at: http://info.k4health.org/pac/strategies/USAID_PAC_Strategy.pdf. 

Appendixes 



\section{Appendix A: Baseline Community Survey Instrument}

12 Population Council

SERIAL NUMBER

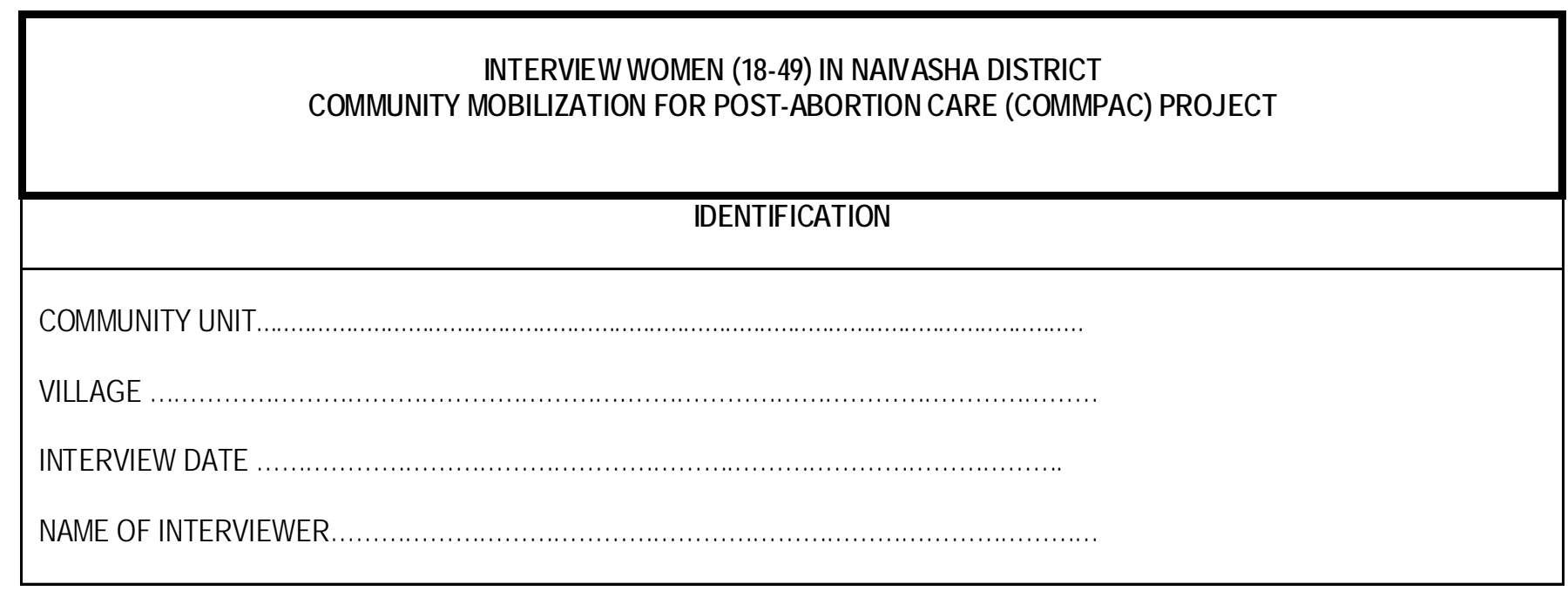

\begin{tabular}{|c|c|c|}
\hline \multicolumn{3}{|l|}{ RESULT CODES } \\
\hline 1=COMPLETED & 4=POSTPONED & 7=PARTLY COMPLEIED \\
\hline 2=NOT ATHOME & 5=RESPONDENT REFUSED & 8=INCAPACTATED \\
\hline 3=AWAYFOR EXTENDED PERIOD & 6=HUSBAND/PARENT REユUSED & $9=$ OTHER(SPECIFY) $\ldots \ldots \ldots \ldots \ldots \ldots \ldots \ldots \ldots$ \\
\hline \multicolumn{2}{|c|}{ 1=KISWAHILI $2=$ ENGLISH $3=$ OTHER(SPECIFY) $\ldots \ldots \ldots \ldots \ldots \ldots \ldots$} & \\
\hline \multicolumn{2}{|c|}{ DATAEDITOR SIGNATUREANDDATE. ................................... } & … \\
\hline
\end{tabular}

Version May 24, 2010 


\title{
Informed Consent Form for Survey Participants
}

\author{
(Community Post-Abortion Care Project [COMMPAC]) \\ RESPOND/Population Council \\ Evaluation of the Replication of the Community Post-Abortion Care Model in Kenya
}

Habari ya asubuhi/mchana. Jina langu ni [Name]. Ninafanya kazi na Shirika la Population Council kwa utafiti kuhusu kuvuja damu katika miezi ya kwanza nusu ya uja uzito katika wanawake wa jamii hii. Tuna mahojiano na mazungumzo na watu wa jamii hii, watu kutoka Wizara ya Afya na wahudumu wa afya kutoka kwa kituo cha afya/zahanati kilichoko hapa ili tupate/tukusanye maoni kuhusu swala/jambo hili.

Purpose of the study: Madhumuni ya utafiti huu ni kuhakikisha ya kwamba wanawake katika jamii hii wanaweza kupata huduma wanazohitaji wanapovuja damu katika miezi ya kwanza nusu ya uja uzito. Tungependa kupata/kutafuta habari kuhusu jambo hili na kuitumia kuboresha jinsi huduma za afya zinavyotolewa kwa wanawake wanaopitia mambo haya na kuelimisha jamii kuhusu jambo hili. Wewe ni mmoja wa kati ya wanawake zaidi ya mia sita ambao wamechaguliwa kushiriki katika utafiti huu.

Maoni yako na uzoefu wako ni muhimu katika kutusaidia kuelewa mahitaji ya wanawake ambao wamekumbana na kuvuja damu katika miezi ya kwanza nusu ya uja uzito ama kwa wale ambao watakumbana nayo siku zijazo. Maoni yako na uzoefu wako pia utasaidia kuhakikisha ya kwamba watu wanaoanzisha miradi na huduma za kushughulukia hili swala wanapata habari iliyo kamili/kweli. Kwa hivyo, tutashukuru kupata usaidizi kutoka kwako. Ukiamua kushiriki katika utafiti huu, nitakuwa na mahojiano pamoja na wewe. Nitakuuliza maswali kuhusu unachojua kuhusu zile huduma za afya zilizoko hapa ambazo hutoa matibabu kwa kuvuja damu katika miezi ya kwanza nusu ya uja uzito pamoja na uzoefu wako na wa wanawake wengine katika jamii hii wa kutumia huduma hizi. Pia, nitakuuliza maswali kuhusu uja uzito, kupanga uzazi, kujifungua watoto na kushiriki kwako katika shughuli za ki-afya katika jamii.

Discomfort and risk: Kuna madhara machache kwako ukishiriki katika mradi huu. Unaweza kutojihisi/kutojisikia kuwa huru ukijibu maswali kadhaa ambayo yanaweza kuonekana kuwa ya kibinafsi na yanayokuingilia sana kwa undani. Lakini, kushiriki kwako katika mradi huu ni kwa hiari yako/kujitolea kabisa. Si lazima ujibu maswali yoyote ambayo hujihisi/hujisikii kuwa huru nayo. Utakuwa na uhuru wa kumuuliza mhoji kusitisha mahojiano usipojisikia kuwa huru, au kukataa kujibu maswali yoyote yatakayokufanya kutojihisi/kutojisikia kuwa huru. Pia, uamuzi wako wa kushiriki au kutoshiriki katika utafiti huu hautaadhiri kwa vyovyote vile uwezo wako wa kupata huduma za afya unazohitaji.

Benefits and compensation: Mradi huu unalenga kuboresha maisha ya wanawake katika jamii hii, kwa kuhakikisha ya kwamba wanaweza kutumia kwa urahisi zaidi huduma katika vituo vya afya vilivyoko hapa; ikiwa watakumbana na kuvuja damu katika miezi ya kwanza nusu ya uja uzito. Tunakuuliza utupatie wakati wako kwa kushiriki katika kikao kimoja cha mahojiano. Hautapokea chochote kwa kushiriki katika mahojiano haya.

Duration of participation: Tunatarajia kwamba mahojiano haya yatachukua muda wa saa moja. Confidentiality: Mahojiano haya yatakuwa ya siri kabisa. Hakuna mtu yeyote atakayeonyeshwa majibu yako. Jina lako litaandikwa tu kwa fomu ya kukubali kushiriki katika utafiti, ambayo itawekwa kando na majibu kutoka kwa mahojiano. Majibu yako yataunganishwa pamoja na majibu ya wanawake wengine mia sita ambao wataulizwa maswali sawa na wewe, na hakuna yeyote atakayeweza kutambua majibu yako. Habari tutakayopata itatumika kwa kazi iliyodhamiriwa peke yake na itatumiwa tu na watafiti wanaohusika katika mradi huu peke yao. Ili kuhakikisha kwamba hakuna yeyote mwingine atakayeweza kutumia habari utakazotupatia, karatasi ya orodha ya maswali tutakayotumia kuandikia majibu yako ya mahojiano itahifadhiwa katika kabati iliyofungwa, huko Population Council. 
Who to call in case of a need: Shida zozote zikitokea kuhusiana/kulingana na utafiti huu au ukiwa na maswali yoyote kuhusu kushiriki kwako katika mradi huu, tafadhali wasiliana na Chi-Chi Undie, Population Council Tel:020-2713480-3 au KEMRI/National Ethical Review Committee Tel:020-2722541.

Pengine sasa, una maswali ya kuniuliza. Nitajibu kwa ukweli/uaminifu maswali yote uliyonayo. Nisipokuwa na habari unayohitaji; nitakuelezea hivyo na ukitaka, nitajaribu kukutafutia jawabu. Una maswali yoyote?

(If yes, note the questions) 1. Yes $\quad$ 2. No

\begin{abstract}
(Answer the questions).
Ningependa kusisitiza kwamba kushiriki kwako katika utafiti huu ni kwa hiari yako kabisa. Si lazima ushiriki kama hutaki. Ikiwa hutaki kujibu swali lolote, una uhuru wa kukataa kufanya hivyo wakati wowote. Pia, uko na uhuru wa kujiondoa kwenye utafiti huu wakati wowote. Uamuzi wa kushiriki au kutoshiriki katika utafiti huu au kujibu maswali fulani hautaadhiri uwezo wako wa kutumia huduma zozote za afya au kupata usaidizi wowote utakaohitaji. Chochote utakachoamua ni sawa/ni kwa hiari yako na hutapata shida yoyote ukiamua kujiondoa au kukataa kuongea na mimi.
\end{abstract}

- Je, unakubali kushiriki katika zoezi hili?

1= YES \& WILLING TO SIGN (OBTAIN SIGNATURE, OR MARK IF NON-LITERATE)

$2=$ YES, BUT PREFER NOT TO SIGN (DO NOT ASK FOR SIGNATURE)

$3=$ NO (END INTERVIEW)

Interviewee's signature

Interviewer's signature

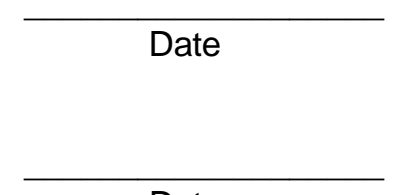

Date 


\section{SECTION B: BACKGROUND CHARACTERISTICS}

\begin{tabular}{|c|c|c|}
\hline Q No. & Questions and filters & Responses and codes \\
\hline BI & $\begin{array}{l}\text { How old are you now? } \\
\text { Una umri wa miaka mingapi kwa sasa? }\end{array}$ & 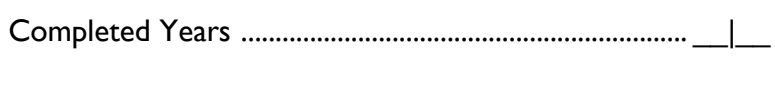 \\
\hline B2 & $\begin{array}{l}\text { What is the highest level of education you have } \\
\text { completed? } \\
\text { Umekamilisha kiwango kipi cha elimu? }\end{array}$ & 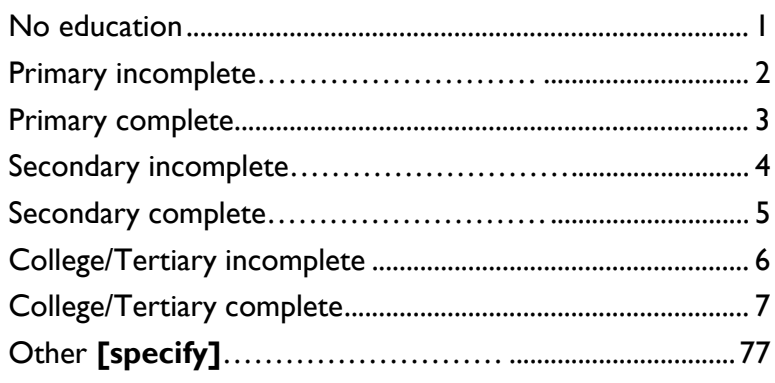 \\
\hline B3 & $\begin{array}{l}\text { Are you currently married? } \\
\text { Je, umeolewa kwa sasa? }\end{array}$ & 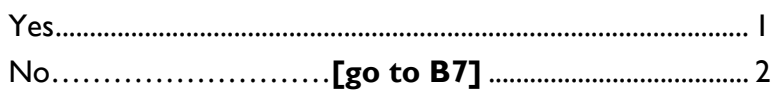 \\
\hline B4 & $\begin{array}{l}\text { How old is your husband? } \\
\text { Mume wako ana umri wa miaka mingapi? }\end{array}$ & Completed Years \\
\hline B5 & $\begin{array}{l}\text { What is the highest level of education that your } \\
\text { husband has completed? } \\
\text { Je, mume wako amekamilisha kiwango kipi cha elimu? }\end{array}$ & 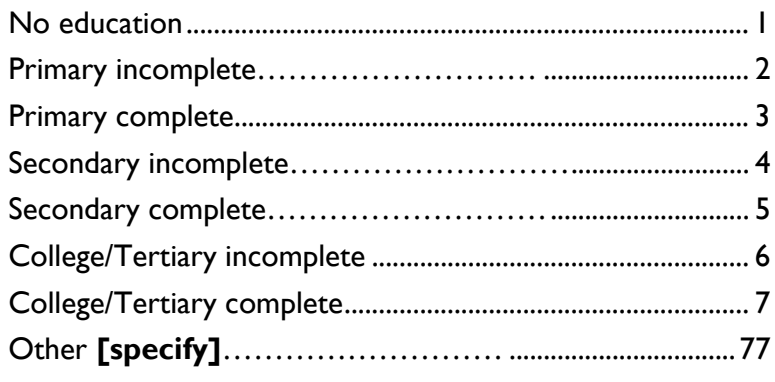 \\
\hline B6 & $\begin{array}{l}\text { What is your husband's main occupation? } \\
\text { Mume wako hufanya kazi gani sanasana? }\end{array}$ & 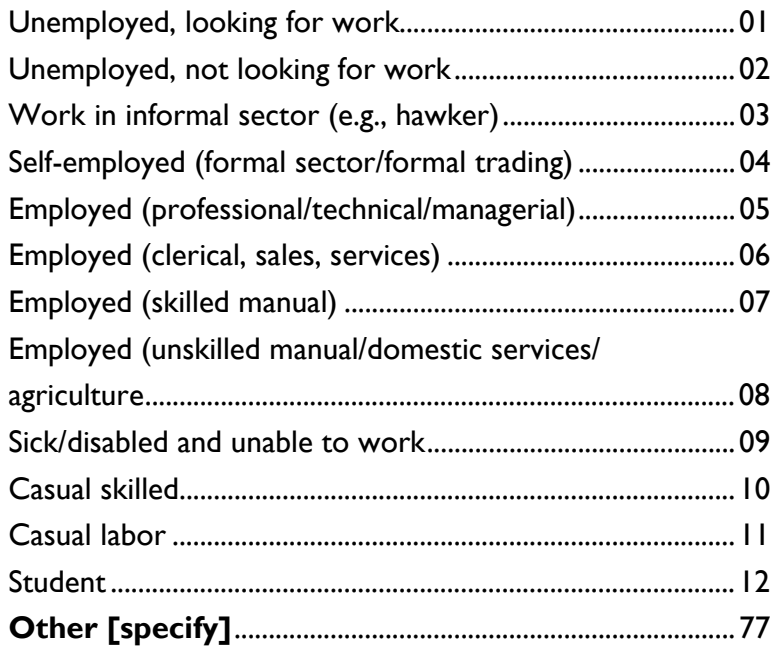 \\
\hline B7 & $\begin{array}{l}\text { Do you do any work other than household work? } \\
\text { Je, wewe hufanya kazi nyingine yoyote kando na kazi ya } \\
\text { nyumba? }\end{array}$ & No \\
\hline
\end{tabular}




\begin{tabular}{|c|c|c|}
\hline Q No. & Questions and filters & Responses and codes \\
\hline B8 & $\begin{array}{l}\text { What is your main occupation? } \\
\text { Wewe hufanya kazi gani sanasana? }\end{array}$ & 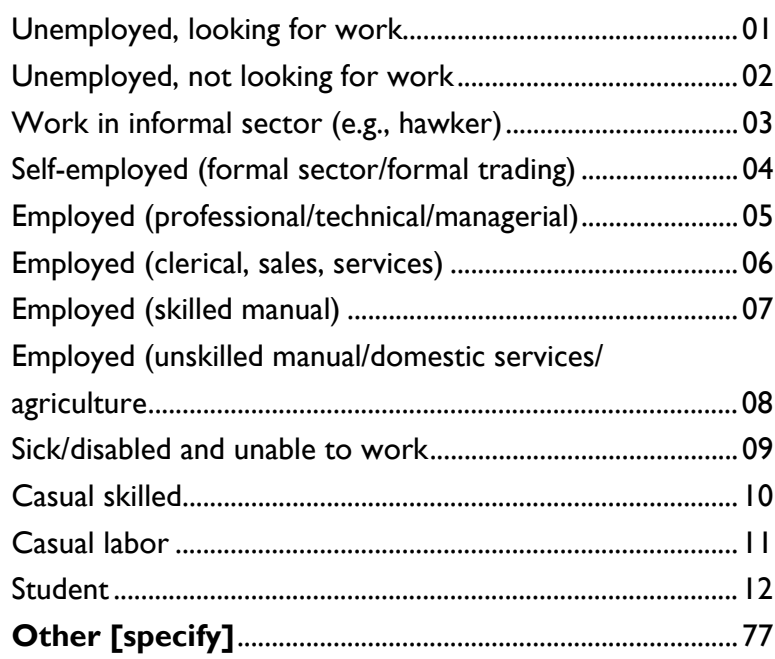 \\
\hline B9 & $\begin{array}{l}\text { What is your religion? } \\
\text { Dini yako ni gani? }\end{array}$ & 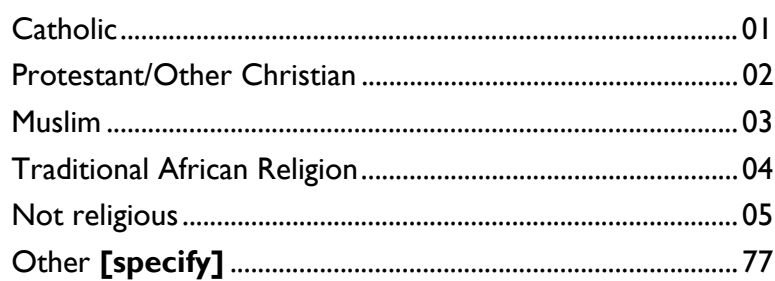 \\
\hline
\end{tabular}

\begin{tabular}{|c|c|c|}
\hline \multirow{2}{*}{$\begin{array}{r}\text { BI0 } \\
\text { a }\end{array}$} & \multicolumn{2}{|c|}{$\begin{array}{l}\text { Now I will list some household items. Please tell me which of these you have in your house: } \\
\text { Nitakusomea baadhi ya vitu vya nyumbani. Tafadhali nielezee vile ambavyo uko navyo: }\end{array}$} \\
\hline & $\begin{array}{l}\text { Radio/Tape recorder } \\
\text { Redio/tepu rekoda }\end{array}$ & Yeso \\
\hline$b$ & $\begin{array}{l}\text { Television } \\
\text { Televisheni/runinga }\end{array}$ & Yeso \\
\hline c & VCR/VCD/DVD & Yeso \\
\hline$d$ & $\begin{array}{l}\text { Refrigerator } \\
\text { Friji/jokofu }\end{array}$ & Yeso \\
\hline e & $\begin{array}{l}\text { Bicycle } \\
\text { Baisikeli }\end{array}$ & Yeso \\
\hline$f$ & $\begin{array}{l}\text { Motorcycle } \\
\text { Pikipiki }\end{array}$ & Yeso \\
\hline $\mathrm{g}$ & $\begin{array}{l}\text { Land line (home phone) } \\
\text { Simu ya land line(simu ya nyumbani) }\end{array}$ & Yeso \\
\hline $\mathrm{h}$ & $\begin{array}{l}\text { Mobile phone [ask: Do you have your own } \\
\text { mobile phone?] } \\
\text { Simu ya mkononi/rununu [ask: Je, uko na simu yako } \\
\text { ya mkononi?] }\end{array}$ & Yeso \\
\hline
\end{tabular}




\begin{tabular}{|c|c|c|}
\hline Q No. & Questions and filters & Responses and codes \\
\hline $\mathrm{BII}$ & $\begin{array}{l}\text { Who owns the house you live in? } \\
\text { Ni nani anayemiliki nyumba unayoishi? }\end{array}$ & $\begin{array}{l}\text { Self } \\
\text { Joint (Husband \& Self) } \\
\text { Parents } \\
\text { In-laws. } 04 \\
\text { Friend/ Neighbor } \\
\text { Relatives } \\
\text { Eandlord } \\
\text { Other [specify] }\end{array}$ \\
\hline $\mathrm{B} 12$ & $\begin{array}{l}\text { How long have you lived in this community? } \\
\text { Je, umeishi katika jamii hii kwa muda upi? }\end{array}$ & 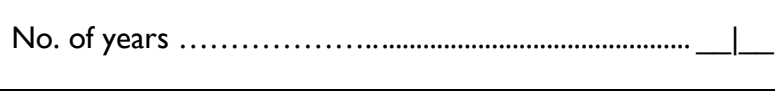 \\
\hline $\mathrm{B} 13$ & $\begin{array}{l}\text { Are you likely to continue living in this community } \\
\text { for the next one year? } \\
\text { Je, huenda ukaendelea kuishi katika jamii hii kwa muda } \\
\text { wa mwaka mmoja ujao? }\end{array}$ & No ${ }^{\prime}$ \\
\hline $\mathrm{B} \mid 4$ & $\begin{array}{l}\text { How many people usually reside and share a } \\
\text { cooking pot with you in this house? } \\
\text { Watu wangapi wanaoishi ndani ya nyumba hii na } \\
\text { mnapika nao? }\end{array}$ & No. of people \\
\hline
\end{tabular}




\section{SECTION C: PREGNANCY and CHILDBEARING}

\section{Now, I would like to ask you some questions about all your pregnancies and the children you have given birth to.}

Sasa ningependa kukuuliza maswali kuhusu uzazi.

\begin{tabular}{|c|c|c|}
\hline Q No. & Questions and filters & Responses and codes \\
\hline $\mathrm{Cl}$ & $\begin{array}{l}\text { Have you ever been pregnant? } \\
\text { Je, ushawahi kuwa mja mzito? }\end{array}$ & Yes \\
\hline $\mathrm{C} 2$ & $\begin{array}{l}\text { Are you currently pregnant? } \\
\text { Je, wewe ni mja mzito kwa sasa? }\end{array}$ & Yes \\
\hline $\mathrm{C} 3$ & $\begin{array}{l}\text { How many months pregnant are you? } \\
\text { Je, una mimba ya miezi mingapi? }\end{array}$ & No. of months \\
\hline $\mathrm{C} 4$ & $\begin{array}{l}\text { Is this your first pregnancy? } \\
\text { Je, hii ndio mimba yako ya kwanza? }\end{array}$ & 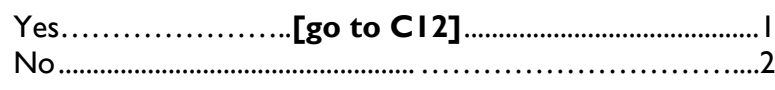 \\
\hline C5 & $\begin{array}{l}\text { How many living children do you have? } \\
\text { Je, una watoto wangapi walio hai? }\end{array}$ & No. of living children \\
\hline $\mathrm{C} 6$ & $\begin{array}{l}\text { Unfortunately, some women lose children after they } \\
\text { are born. Has this ever happened to you? } \\
\text { Kwa bahati mbaya, wanawake wengine huwapoteza } \\
\text { watoto baada ya kujifungua. Je, jambo hili limeshawahi } \\
\text { kukutendekea? }\end{array}$ & No \\
\hline $\mathrm{C7}$ & $\begin{array}{l}\text { How many of your children have died? } \\
\text { Ni watoto wangapi wako ambao wamefariki/wameaga } \\
\text { dunia? }\end{array}$ & No. of children that died ...................................................._. \\
\hline $\mathrm{C} 8$ & $\begin{array}{l}\text { Have you ever had a pregnancy which did not come } \\
\text { to term? } \\
\text { Je, umeshawahi kuwa na mimba ambayo ilitoka? }\end{array}$ & 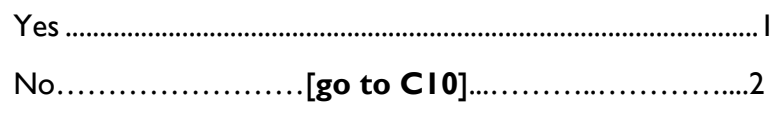 \\
\hline C9 & $\begin{array}{l}\text { How many times has this happened? } \\
\text { Jambo hili limetendekallimefanyika mara ngapi? }\end{array}$ & No. of times \\
\hline $\mathrm{ClO}$ & $\begin{array}{l}\text { Have you ever had any pregnancy where, } \\
\text { unfortunately, the child was born stillborn (i.e., } \\
\text { without breathing?) } \\
\text { Je, umeshawahi kuwa na mimba ambayo; kwa bahati } \\
\text { mbaya, mtoto alizaliwa kama amefariki? }\end{array}$ & 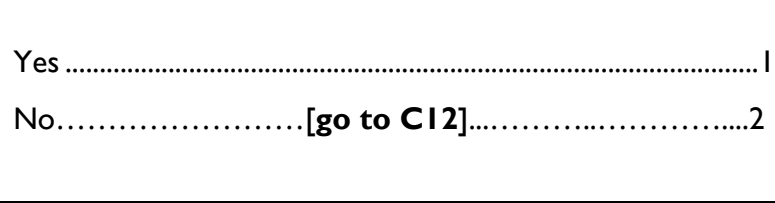 \\
\hline $\mathrm{CII}$ & $\begin{array}{l}\text { How many times has this happened? } \\
\text { Jambo hili limetendekallimefanyika mara ngapi? }\end{array}$ & No. of times \\
\hline $\mathrm{Cl} 2$ & $\begin{array}{l}\text { So, let's see now: Am I correct in saying that you } \\
\text { have given birth to } \\
\text { Sasa, wacha tuone: Je, niko sawa nikisema kwamba } \\
\text { umejifungua (jumla ya) watoto } \\
\text { Add C5 ('No. of living children') to } \\
\text { C7 ('No. of children that died'), then } \\
\text { record the total ['Total children } \\
\text { born (live births)]. }\end{array}$ & Total children born (live births) ………………….............__ \\
\hline
\end{tabular}




\begin{tabular}{|c|c|c|}
\hline Q No. & Questions and filters & Responses and codes \\
\hline \multicolumn{3}{|c|}{ Check C4. If this is respondent's first pregnancy, go to CI5. } \\
\hline $\mathrm{Cl} 3$ & $\begin{array}{l}\text { Were you pregnant in the last one year? } \\
\text { Je, ulikuwa mja mzito katika muda wa mwaka mmoja } \\
\text { uliopita? }\end{array}$ & Yes \\
\hline $\mathrm{Cl} 4$ & $\begin{array}{l}\text { What was the outcome of the pregnancy? } \\
\text { Je, matokeo ya mimba hiyo yalikuwa yapi? }\end{array}$ & Still pregnant \\
\hline CI5 & $\begin{array}{l}\text { Calculate and fill out Total Pregnancies (do } \\
\text { not ask) } \\
\text { [add } \mathrm{C5}+\mathrm{C7}+\mathrm{C} 9+\mathrm{CI} \text { I to find the Total } \\
\text { Number of Pregnancies] }\end{array}$ & Total Number of Pregnancies \\
\hline
\end{tabular}




\section{SECTION D: FAMILY PLANNING KNOWLEDGE}

Now I would like to ask some questions about family planning - that is, methods people use to prevent/delay pregnancy.

Ningependa kuuliza maswali kuhusu upangaji uzazi. Yaani, kuzuia au kuchelewesha uja uzito.

\begin{tabular}{|c|c|c|c|}
\hline Q No. & Questions and filters & & Responses and codes \\
\hline DI & $\begin{array}{l}\text { Have you ever heard about any methods to prevent or delay } \\
\text { pregnancy? } \\
\text { Je, umewahi kusikia kuhusu njia zozote za kuzuia au kuchelewesha } \\
\text { mimba? }\end{array}$ & \multicolumn{2}{|c|}{ Yes } \\
\hline \multicolumn{2}{|c|}{$\begin{array}{l}\text { D2 } \\
\text { Which methods of contraception are you aware of? } \\
\text { Je, unafahamu njia zipi za kuzuia mimba? }\end{array}$} & \multicolumn{2}{|c|}{$\begin{array}{l}\text { M=MENTIONED } \\
\text { NM=NOT MENTIONED }\end{array}$} \\
\hline A & Pill: a pill taken every day by women & I & 2 \\
\hline B & $\begin{array}{l}\text { IUD (Copper T): a loop or coil placed inside women by a } \\
\text { doctor }\end{array}$ & I & 2 \\
\hline C & $\begin{array}{l}\text { Injections: an injection which stops women from becoming } \\
\text { pregnant for several months }\end{array}$ & I & 2 \\
\hline $\mathrm{D}$ & $\begin{array}{l}\text { Condom: a rubber sheath put on men's penis during sexual } \\
\text { intercourse }\end{array}$ & I & 2 \\
\hline $\mathrm{E}$ & $\begin{array}{l}\text { Implants: women can have small rods placed in their upper arm } \\
\text { by a doctor or nurse which can prevent pregnancy for one or } \\
\text { more years. }\end{array}$ & I & 2 \\
\hline $\mathrm{F}$ & Withdrawal: men can be careful and pull out before ejaculation & I & 2 \\
\hline G & $\begin{array}{l}\text { Female Sterilization: an operation for women to avoid having } \\
\text { any more children }\end{array}$ & I & 2 \\
\hline $\mathrm{H}$ & $\begin{array}{l}\text { Male Sterilization: an operation for men to avoid having any } \\
\text { more children }\end{array}$ & I & 2 \\
\hline 1 & $\begin{array}{l}\text { Emergency Contraceptive: Women can take pills or have an } \\
\text { IUD inserted up to five days after unprotected sexual } \\
\text { intercourse to avoid becoming pregnant. }\end{array}$ & 1 & 2 \\
\hline J & $\begin{array}{l}\text { Lactational Amen. Method: women can avoid pregnancy by } \\
\text { exclusively breastfeeding their baby (no other foods or liquids) if } \\
\text { the woman's menses have not returned and the baby is less than } \\
6 \text { months old. }\end{array}$ & I & 2 \\
\hline
\end{tabular}




\begin{tabular}{|c|c|c|c|}
\hline Q No. & \multicolumn{2}{|l|}{ Questions and filters } & Responses and codes \\
\hline K & $\begin{array}{l}\text { Standard Days Method: Use colored beads to keep track of } \\
\text { menstrual cycle and only have sexual intercourse on the "safe" } \\
\text { days when the woman is unlikely to be fertile. }\end{array}$ & 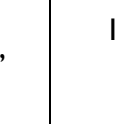 & 2 \\
\hline $\mathrm{L}$ & $\begin{array}{l}\text { Fertility awareness methods (Rhythm, Periodic Abstinence): } \\
\text { Avoid having sexual intercourse on the days of the month } \\
\text { woman is likely to get pregnant }\end{array}$ & I & 2 \\
\hline M & Other: ask respondent to describe: & I & 2 \\
\hline Q No. & Questions and filters & \multicolumn{2}{|r|}{ Responses and codes } \\
\hline D3 & $\begin{array}{l}\text { From which sources of information have you heard/seen/ } \\
\text { read about family planning? } \\
\text { Je, umesikia au kuona au kusoma kuhusu njia za upangaji } \\
\text { uzazi na nikupitia njia zipi? } \\
\text { - Do not read out answers. } \\
\text { - Circle all mentioned. }\end{array}$ & $\begin{array}{l}\text { Govt. he } \\
\text { Pvt. heal } \\
\text { Pharmac } \\
\text { CBO/N } \\
\text { TBA...... } \\
\text { Husbanc } \\
\text { Relative/ } \\
\text { Radio/T } \\
\text { Newspa } \\
\text { Poster... } \\
\text { CHW.... } \\
\text { Commu } \\
\text { Other [ }\end{array}$ & hemist facility hBom \\
\hline D4 & $\begin{array}{l}\text { In this community, where do people go to get family } \\
\text { planning methods? } \\
\text { Katika jamii hii, watu huenda wapi kupata njia za kupanga } \\
\text { uzazi? } \\
\text { - Circle all mentioned. }\end{array}$ & $\begin{array}{l}\text { Govt. he } \\
\text { Pvt. heal } \\
\text { Pharmac } \\
\text { CBO/N } \\
\text { TBA...... } \\
\text { Herbalis } \\
\text { Other [ }\end{array}$ & hemility facility \\
\hline \multirow[t]{2}{*}{ D5 } & $\begin{array}{l}\text { Overall, do you approve of the idea of contraceptives } \\
\text { (meaning family planning) or disapprove? } \\
\text { Kwa ujumla, unaunga mkono matumizi ya njia za kuzuia } \\
\text { mimba (yaani kupanga uzazi) ama unapinga? }\end{array}$ & $\begin{array}{l}\text { Approve } \\
\text { Neither } \\
\text { Oppose. } \\
\text { Don't kr }\end{array}$ & rove nor disapprove \\
\hline & \multicolumn{3}{|l|}{ Check B3. If not married, go to D7. } \\
\hline D6 & $\begin{array}{l}\text { Overall, does your husband approve of the idea of } \\
\text { contraceptives, (meaning family planning) or disapprove? } \\
\text { Kwa ujumla, mume wako anaunga mkono matumizi ya njia } \\
\text { za kuzuia mimba (yaani kupanga uzazi) ama anapinga? }\end{array}$ & $\begin{array}{l}\text { Approve } \\
\text { Neither a } \\
\text { Oppose... } \\
\text { Don't knc }\end{array}$ & ove nor disapprove \\
\hline D7 & Check C2. If respondent is currently pregnant, go & 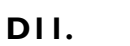 & \\
\hline
\end{tabular}




\begin{tabular}{|c|c|c|}
\hline Q No. & Questions and filters & Responses and codes \\
\hline D8 & $\begin{array}{l}\text { Are you currently using any form of family planning? } \\
\text { Je, unatumia njia yoyote ya kupanga uzazi kwa wakati huu? }\end{array}$ & 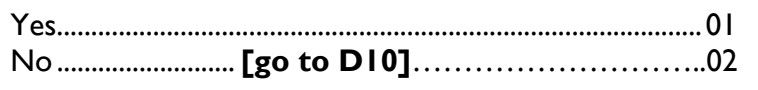 \\
\hline D9 & $\begin{array}{l}\text { What family planning method(s) are you currently using? } \\
\text { Je, unatumia njia zipi za kupanga uzazi kwa wakati huu? } \\
\text { Anything else? } \\
\text { Njia nyingine? } \\
\text { - Circle only one option - except for those } \\
\text { using double protection - i.e., condoms } \\
\text { plus another method. } \\
\text { - After circling option, skip to DI2. }\end{array}$ & $\begin{array}{l}\text { Pills } \\
\text { IUD (Copper T) } \\
\text { Condoms } \\
\text { Implants } \\
\text { Fertility awareness method } \\
\text { Withdrawal } \\
\text { Female sterilization } \\
\text { Male sterilization } \\
\text { Emergency contraceptivenational amen. method } \\
\text { Standard days method } \\
\text { Other [Specify] }\end{array}$ \\
\hline DIO & $\begin{array}{l}\text { What are the reasons you are not currently using a family } \\
\text { planning method? } \\
\text { Ni kwa sababu gani hautumii njia yoyote ya kupanga uzazi kwa } \\
\text { sasa? } \\
\text { - Circle all mentioned. }\end{array}$ & $\begin{array}{l}\text { Not married. } \\
\text { FERTILITY-RELATED REASONS } \\
\text { Not having sex. } \\
\text { Infrequent sex. } \\
\text { Menopausal/hysterectomy } \\
\text { Subfecund/infecund } \\
\text { Breastfeeding } \\
\text { Fatalistic } \\
\text { OPPOSITION TO USE } \\
\text { Respondent opposed } \\
\text { Husband/partner opposed } \\
\text { Others opposed } \\
\text { Religious prohibition } \\
\text { LACK OF KNOWLEDGE } \\
\text { Knows no method. } \\
\text { Knows no source } \\
\text { METHOD-RELATED REASONS } \\
\text { Health concerns } \\
\text { Fear of side effects. } \\
\text { Lack of access/too far. } \\
\text { Costs too much } \\
\text { Inconvenient to use. } \\
\text { Interferes with body's natural processes } \\
\text { Don't know } \\
\text { Other [Specify] }\end{array}$ \\
\hline DII & $\begin{array}{l}\text { Do you think you will use a family planning method in the } \\
\text { future? } \\
\text { Je, unafikiria kuwa utatumia njia ya kupanga uzazi siku za } \\
\text { usoni/baadaye? }\end{array}$ & 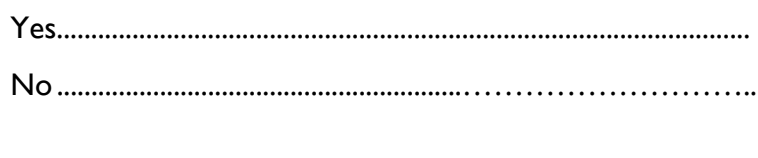 \\
\hline
\end{tabular}

Check $\mathrm{Cl}$ to verify if respondent has ever been pregnant.

Check $C 2$ to verify if respondent is currently pregnant.

\begin{tabular}{|c|c|c|}
\hline $\mathrm{D} 12$ & $\begin{array}{l}\text { Would you like to have a/another child in the future? } \\
\text { Je, ungependa kupata mtoto/watoto mwingine siku za } \\
\text { usoni/baadaye? } \\
\text { If woman is currently pregnant: After this pregnancy, } \\
\text { would you like to have another child? } \\
\text { Je, ungependa kupata mtoto mwingine baada ya hii mimba }\end{array}$ & 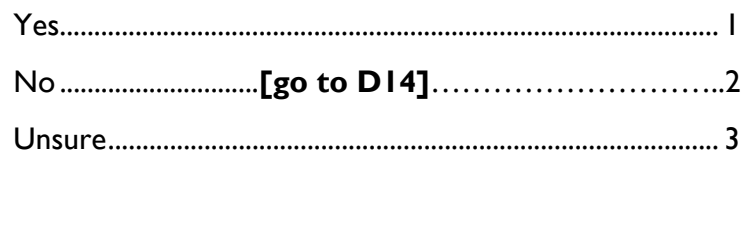 \\
\hline
\end{tabular}




\begin{tabular}{|c|c|c|}
\hline Q No. & Questions and filters & Responses and codes \\
\hline DI3 & $\begin{array}{l}\text { When do you want to become pregnant with a/another child } \\
\text { [i.e., when do you want to CONCEIVE again]? } \\
\text { Ni lini ungependa kuwa mja mzito? [i.e., when do you want } \\
\text { to CONCEIVE again]? } \\
\text { If woman is currently pregnant: After this pregnancy, } \\
\text { when do you want to become pregnant with another child } \\
\text { [i.e., when do you want to CONCEIVE again]? } \\
\text { Baada ya hii mimba, ni lini ungependa kuwa mja mzito? [i.e., } \\
\text { when do you want to CONCEIVE again]? }\end{array}$ & 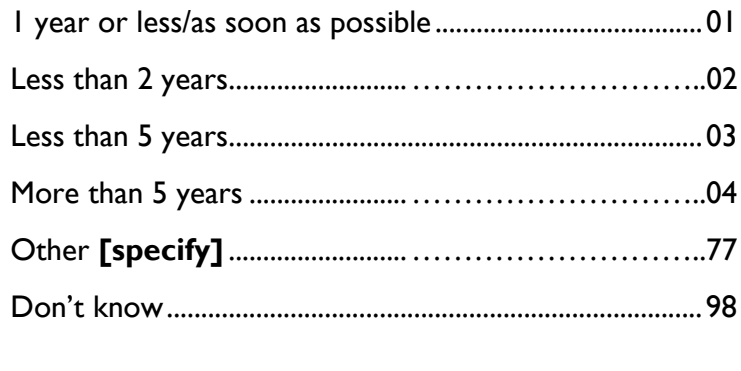 \\
\hline \multicolumn{3}{|c|}{ Go to DI5 } \\
\hline DI4 & $\begin{array}{l}\text { What is your reason for not wanting a/another child? } \\
\text { Una sababu gani ya kutotaka mtoto/mtoto mwingine? }\end{array}$ & 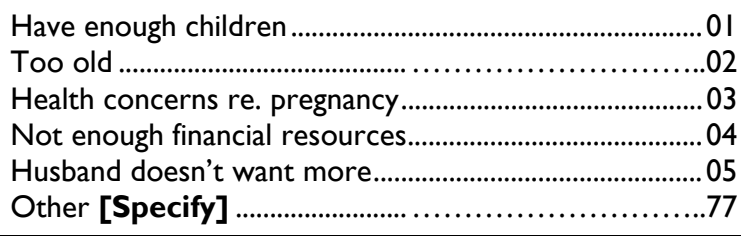 \\
\hline DI5 & $\begin{array}{l}\text { Have you and your husband/partner ever discussed the idea } \\
\text { of using/doing something to delay or prevent pregnancy? } \\
\text { Je, wewe na mume/mpenzi wako mshawahi kuzungumzia swala } \\
\text { la kutumia/au kufanya chochote ili kuchelewesha ama kuzuia } \\
\text { mimba? }\end{array}$ & $\begin{array}{l}\text { Yes } \\
\text { No } / A \\
99\end{array}$ \\
\hline DI6 & $\begin{array}{l}\text { When would your husband/partner like you to become } \\
\text { pregnant with a/another child [i.e., when would he like } \\
\text { you to CONCEIVE]? } \\
\text { Ni lini mume/mpenzi wako angependa uwe mja mzito na } \\
\text { mtoto/mtoto mwingine? [i.e., when would he like you want } \\
\text { to CONCEIVE again]? }\end{array}$ & 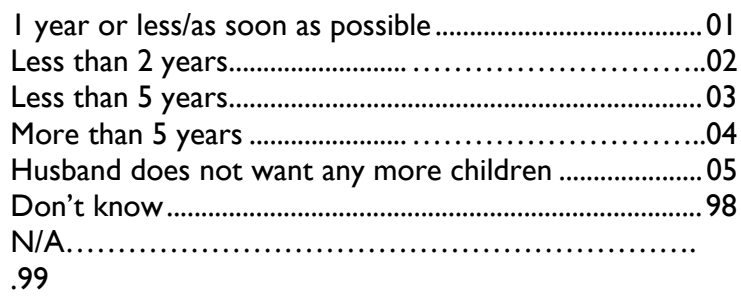 \\
\hline \multicolumn{3}{|c|}{ Check CI. If respondent has never been pregnant, go to DI 8.} \\
\hline DI7 & $\begin{array}{l}\text { Has there been a time in the past when you got pregnant } \\
\text { unintentionally? } \\
\text { Je, kuna wakati wowote ambao ushawahi kupata mimba bila ya } \\
\text { kutarajia? }\end{array}$ & Yeso I \\
\hline
\end{tabular}




\begin{tabular}{|c|c|c|c|c|}
\hline & Questions and filters & & ponse & and codes \\
\hline \multirow[t]{12}{*}{ DI8 } & \multirow{2}{*}{$\begin{array}{l}\text { In this community, what would be acceptable reasons why a } \\
\text { woman may not want a pregnancy? } \\
\text { Katika jamii hii, ni sababu zipi zinazokubalika kwa mwanamke } \\
\text { kutotaka/kutokubali kuwa na mimba fulani? }\end{array}$} & Situation & Yes & No \\
\hline & & $\begin{array}{l}\text { a. Has enough } \\
\text { children }\end{array}$ & 1 & 2 \\
\hline & \multirow{10}{*}{$\begin{array}{l}\text { Any other reason? } \\
\text { Sababu nyingine? } \\
\text { - Do not read out. } \\
\text { - Circle all mentioned. }\end{array}$} & b. After one child & 1 & 2 \\
\hline & & $\begin{array}{l}\text { c. Previous child is } \\
\text { too young }\end{array}$ & 1 & 2 \\
\hline & & $\begin{array}{l}\text { d. Difficult } \\
\text { economic } \\
\text { condition }\end{array}$ & 1 & 2 \\
\hline & & $\begin{array}{l}\text { e. If the fetus is a } \\
\text { female }\end{array}$ & 1 & 2 \\
\hline & & $\begin{array}{l}\text { f. Pregnancy could } \\
\text { harm her health }\end{array}$ & 1 & 2 \\
\hline & & $\begin{array}{l}\text { g. Pregnancy from } \\
\text { premarital or illicit } \\
\text { relationship }\end{array}$ & 1 & 2 \\
\hline & & h. Abnormal fetus & 1 & 2 \\
\hline & & i. Woman is HIV+ & 1 & 2 \\
\hline & & $\begin{array}{l}\text { j. Pregnancy as a } \\
\text { result of rape }\end{array}$ & 1 & 2 \\
\hline & & $\begin{array}{l}\text { k. Other } \\
\text { [Specify] }\end{array}$ & 1 & 2 \\
\hline
\end{tabular}




\section{SECTION E: KNOWLEDGE AND UTILIZATION OF HEALTH SERVICES}

Now I would like us to talk about your experiences through pregnancy and delivery, the types of care you received, complications that can happen early in pregnancies, and how people manage these health issues.

Sasa ningependa tuongee kuhusu uzoefu wako wa ujauzito na kujifungua, huduma ulizopata, shida zinazowezatokea katika miezi ya kwanza ya uja uzito na vile watu hushughulikia matatizo haya ya kiafya.

\begin{tabular}{|c|c|c|}
\hline EI & $\begin{array}{l}\text { Where do most women in this community go to seek } \\
\text { antenatal care (i.e., medical care to make sure a woman } \\
\text { has a healthy pregnancy)? } \\
\text { Je, ni wapi wanawake wengi katika jamii hii huenda } \\
\text { kupata/kupokea utunzi wa akinamama waja wazito? } \\
\text { Probe for the name of the facility/place: } \\
\text { response code. }\end{array}$ & $\begin{array}{l}\text { Govt hospital/clinic } \\
\text { Govt health center } \\
\text { Dispensary } \\
\text { Pvt hospital/clinic } \\
\text { TBA's home } \\
\text { Nowhere/They don't go } \\
\text { Other [specify] }\end{array}$ \\
\hline & - Circle all mentioned. & \\
\hline E2 & $\begin{array}{l}\text { Where do most women in this community go for delivery } \\
\text { (to give birth)? } \\
\text { Je, ni wapi wanawake wengi katika jamii hii huenda } \\
\text { kujifungua? } \\
\text { - Circle all mentioned. }\end{array}$ & $\begin{array}{l}\text { Govt hospital/clinic } \\
\text { Govt health center } \\
\text { Dispensary } \\
\text { Pvt hospital/clinic } \\
\text { TBA's home } \\
\text { At home } \\
\text { Other [specify] }\end{array}$ \\
\hline E3 & $\begin{array}{l}\text { Where do most women in this community go for } \\
\text { postnatal checkups (i.e., medical care after giving birth to } \\
\text { make sure the woman is healthy)? } \\
\text { Je,ni wapi wanawake wengi katika jamii hii huenda } \\
\text { kupatalkupokea utunzi wa akina mama baada ya kujifungua? } \\
\text { - Circle all mentioned. }\end{array}$ & $\begin{array}{l}\text { Govt hospital/clinic } \\
\text { Govt health center } \\
\text { Dispensary } \\
\text { Pvt hospital/clinic } \\
\text { TBA's home } \\
\text { Nowhere/They don't go } \\
\text { Other [specify] }\end{array}$ \\
\hline E4 & $\begin{array}{l}\text { Where do most women in this community go for } \\
\text { checkups for their baby? } \\
\text { Je, ni wapi wanawake wengi katika jamii hii huenda } \\
\text { kupatalkupokea utunziluchunguzi wa watoto wao? } \\
\text { - Circle all mentioned. }\end{array}$ & $\begin{array}{l}\text { Govt hospital/clinic } \\
\text { Govt health center } \\
\text { Dispensary } \\
\text { Pvt hospital/clinic } \\
\text { TBA's home } \\
\text { Nowhere/They don't go } \\
\text { Other [specify] }\end{array}$ \\
\hline
\end{tabular}

- Check C2 and CI3. If respondent is currently pregnant (C2), ask about the current pregnancy. If respondent had been pregnant in the last one year $(\mathrm{CI})$, then ask about that pregnancy.

- If respondent was not pregnant in the last one year, is not currently pregnant, or has never been pregnant [check CI to confirm], go to FI.

- If respondent is currently pregnant, use the PRESENT TENSE to ask the remaining questions in this section. 


\begin{tabular}{|c|c|c|}
\hline E5 & $\begin{array}{l}\text { During your [last/current] pregnancy, did you see } \\
\text { anyone for antenatal care? } \\
\text { Je, [ulipokuwa/ulivyo] mja mzito [mara ya } \\
\text { mwisho/wakati huu]; ulimwona mtu yeyote ili kupokea } \\
\text { utunzi wa mama waja wazito? }\end{array}$ & No \\
\hline E6 & $\begin{array}{l}\text { Whom did you see? Anyone else? } \\
\text { Ulimwona nani? Nani mwingine? } \\
\text { - Probe for the type of person seen } \\
\text { - Circle all mentioned. }\end{array}$ & $\begin{array}{l}\text { Doctor } \\
\text { Nurse/midwife } \\
\text { TBA } \\
\text { Other [specify] }\end{array}$ \\
\hline E7 & $\begin{array}{l}\text { What is the name of the closest health facility that a } \\
\text { pregnant woman in this community can go to for care? } \\
\text { Katika jamii hii, ni kituo kipi cha afyakilicho karibu ambacho } \\
\text { akina mama wajamzito huenda kupata huduma? }\end{array}$ & Name \\
\hline E8 & $\begin{array}{l}\text { Where did you receive antenatal care for your } \\
\text { [last/current] pregnancy? } \\
\text { Je, ni wapi [ulipokeal unapopokea] utunzi wa akina } \\
\text { mama wajawazito [ukiwalulipokuwa] na [hiyo/hii] } \\
\text { mimba? } \\
\text { Anywhere else? Mahali pengine? } \\
\text { - Do not read out. } \\
\text { - Circle all mentioned. }\end{array}$ & 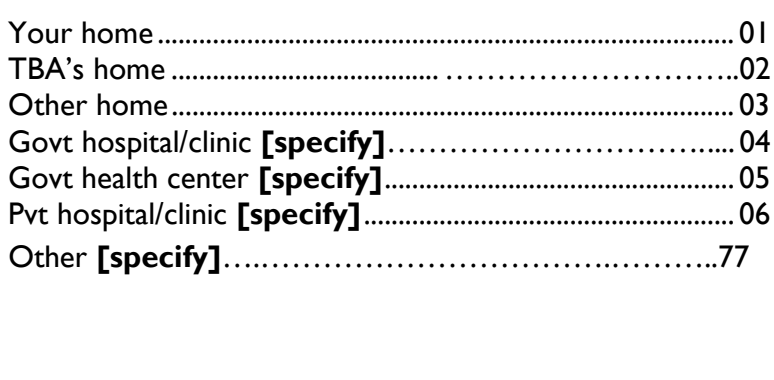 \\
\hline E9 & $\begin{array}{l}\text { How many months pregnant were you when you first } \\
\text { received antenatal care for this pregnancy? } \\
\text { Ulikuwa mja mzito wa miezi mingapi, mara ya kwanza } \\
\text { ulipopokea utunzi wa mama waja wazito kwa hiyo mimba? }\end{array}$ & 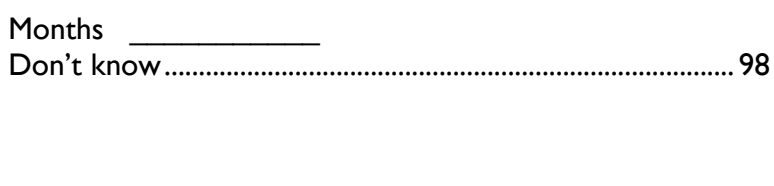 \\
\hline EIO & $\begin{array}{l}\text { How many times did you receive antenatal care during } \\
\text { this pregnancy? } \\
\text { Ni mara ngapi ulipokea utunzi wa mama waja wazito wakati } \\
\text { ulipokuwa na mimba hiyo? }\end{array}$ & 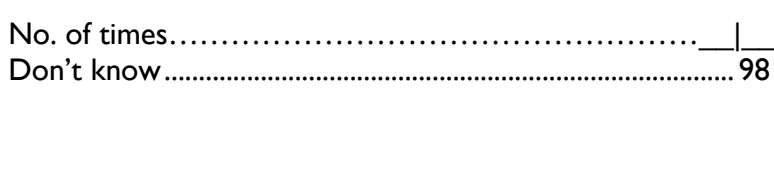 \\
\hline EII & $\begin{array}{l}\text { What services did you receive during your antenatal care } \\
\text { visits? } \\
\text { Ulipokea huduma zipi wakati wa matembezi yako ya kupata } \\
\text { utunzi wa mama waja wazito? } \\
\text { Anything else? Huduma nyingine? } \\
\text { If currently pregnant: What services have you } \\
\text { received so far during your antenatal care visits? Anything } \\
\text { else? } \\
\text { Umepokea huduma gani wakati wa matembezi yako ya } \\
\text { kupata utunzi wa mama waja wazito? Huduma nyingine? } \\
\text { Circle all mentioned. }\end{array}$ & 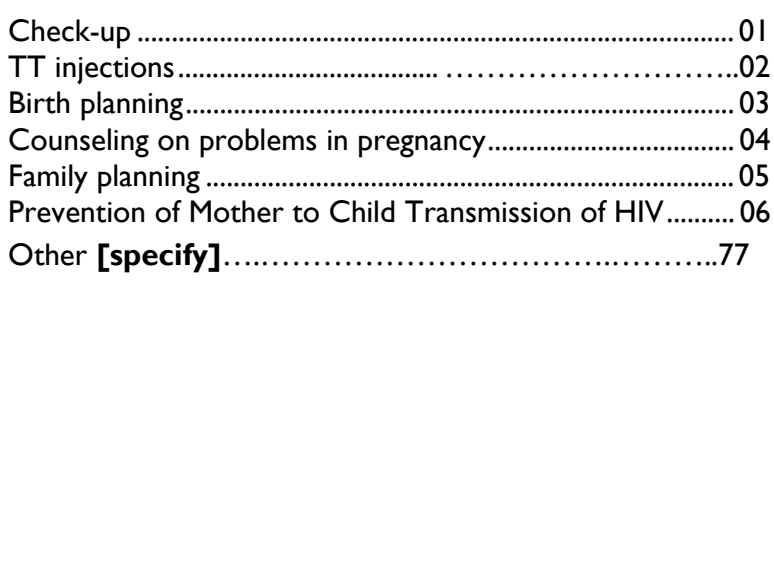 \\
\hline
\end{tabular}

Check C2. If currently pregnant, go to FI. 


\begin{tabular}{|c|c|c|}
\hline $\mathrm{E} 12$ & $\begin{array}{l}\text { Where did the delivery take place? } \\
\text { Ulijifungualia wapi? } \\
\text { If place is hospital, health center, or clinic, write the } \\
\text { name of the place and circle the appropriate code. }\end{array}$ & $\begin{array}{l}\text { Respondent's home } \\
\text { TBA's home } \\
\text { Other home } \\
\text { Govt. Hospital/Clinic } \\
\text { Govt. Health Center } \\
\text { Private Hospital/Clinic } \\
\text { Other[specify] }\end{array}$ \\
\hline & Name: & \\
\hline EI3 & $\begin{array}{l}\text { Who assisted with the delivery of this pregnancy? } \\
\text { Ni nani aliyekusaidia wakati wa kujifungua mimba hiyo? }\end{array}$ & $\begin{array}{l}\text { Doctor } \\
\text { Nurse/midwife } \\
\text { TBA } \\
\text { Relative/friend } \\
\text { No one } \\
\text { Other [specify] }\end{array}$ \\
\hline
\end{tabular}




\section{SECTION F: EXPERIENCE OF PREGNANCY COMPLICATIONS}

\begin{tabular}{|c|c|c|c|c|c|}
\hline \multirow{2}{*}{$\begin{array}{l}\text { Q. No. } \\
\text { FI }\end{array}$} & Questions & \multicolumn{4}{|c|}{ Codes } \\
\hline & $\begin{array}{l}\text { Sometimes, women get pregnant when they do not want } \\
\text { to be. Do you know of any woman who has experienced } \\
\text { this? } \\
\text { Wakati mwingine, wanawake hushika mimba hata kama } \\
\text { hawataki (kushika mimba hiyo). Je, unajua mwanamke yeyote } \\
\text { ambaye amepitia jambo kama hili? }\end{array}$ & \multicolumn{4}{|c|}{ Yes } \\
\hline \multirow[t]{8}{*}{ F2 } & $\begin{array}{l}\text { Sometimes, women experience problems during } \\
\text { pregnancy and delivery. }\end{array}$ & & & YES & $\mathrm{NO}$ \\
\hline & $\begin{array}{l}\text { Wakati mwingine, wanawake hupata shida wakati wa uja } \\
\text { uzito na wakati wa kujifungua. }\end{array}$ & $\mathrm{a}$ & $\begin{array}{l}\text { Problems of bleeding during } \\
\text { the first few months of } \\
\text { pregnancy? }\end{array}$ & $\mathrm{I}$ & 2 \\
\hline & $\begin{array}{l}\text { Have you heard of anybody who had .... } \\
\text { Umeshawahi kusikia kuhusu mtu yoyote ambaye alikuwa na }\end{array}$ & $\mathrm{b}$ & $\begin{array}{l}\text { Problems of bleeding in late } \\
\text { pregnancy? }\end{array}$ & $\mathrm{I}$ & 2 \\
\hline & $\ldots:$ & C & $\begin{array}{l}\text { Problems during delivery, } \\
\text { such as long labor? }\end{array}$ & $\mathrm{I}$ & 2 \\
\hline & & $d$ & $\begin{array}{l}\text { Problems during delivery, } \\
\text { such as the baby coming out } \\
\text { feet first (breech birth)? }\end{array}$ & $\mathrm{I}$ & 2 \\
\hline & & $\mathrm{e}$ & $\begin{array}{l}\text { Problems of bleeding too } \\
\text { much during delivery? }\end{array}$ & I & 2 \\
\hline & & $f$ & Problems after delivery? & I & 2 \\
\hline & & $g$ & Other [specify] & $\mathrm{I}$ & 2 \\
\hline F3 & $\begin{array}{l}\text { There are some diseases that women can get through } \\
\text { having sex with a person infected with that disease. } \\
\text { Kuna magonjwa mengine ambayo wanawake wanaweza } \\
\text { kupata, kupitia kwa kufanya mapenzi na mtu ambaye } \\
\text { ameambukizwa ugonjwa huo. } \\
\text { Would you say the following statement is true or false: } \\
\text { Unaweza kusema kuwa taarifa ifuatayo ni ukweli au uwongo: } \\
\text { "Having a sexually-transmitted disease can result in a } \\
\text { woman having a miscarriage." } \\
\text { "Kupata ugonjwa wa zinaa unaweza kusababisha mimba kwa } \\
\text { mwanamke kutokalkuharibika." }\end{array}$ & \multicolumn{4}{|c|}{ False } \\
\hline F4 & $\begin{array}{l}\text { Sometimes, when a woman is pregnant, she may } \\
\text { experience some problems that indicate the pregnancy is } \\
\text { in danger. What danger signs or complications in early } \\
\text { pregnancy have you heard of? } \\
\text { Wakati mwingine mwanamke akiwa mja mzito; anaweza } \\
\text { kuwa na ishara fulani zinazoashirialonyesha kwamba mimba } \\
\text { hiyo iko hatarini, umesikia kuhusu dalili zipi za hatari au shida } \\
\text { zinazoweza kutokea mwanzoni mwa uja uzito? } \\
\text { Anything else? } \\
\text { Kitu kingine? } \\
\quad \text { Circle all mentioned. }\end{array}$ & \multicolumn{4}{|c|}{$\begin{array}{l}\text { Increased bleeding } \\
\text { Bleeding heavier than a normal period } \\
\text { Continued bleeding for } 2 \text { weeks. } \\
\text { Severe abdominal pain } \\
\text { Fever } \\
\text { Chills } \\
\text { Foul-smelling vaginal discharge } \\
\text { Muscle aches } \\
\text { Tenderness to pressure in abdomen } \\
\text { Dizziness or fainting } \\
\text { Feeling ill, weakness } \\
\text { Nausea or vomiting } \\
\text { Severe and constant headache } \\
\text { Other [specify] }\end{array}$} \\
\hline
\end{tabular}




\begin{tabular}{|c|c|c|}
\hline Q. No. & Questions & Codes \\
\hline F5 & $\begin{array}{l}\text { What are all the places or people you know of that a } \\
\text { woman in this community can go to for help if she is } \\
\text { experiencing bleeding in the first few months of } \\
\text { pregnancy? } \\
\text { Any other place? } \\
\text { Ni mahali gani unapojua, mwanamke katika jamii hii anaweza } \\
\text { kuenda kupata usaidizi; ikiwa anavuja damu katika miezi ya } \\
\text { kwanza ya uja uzito? }\end{array}$ & $\begin{array}{l}\text { Govt hospital/clinic } \\
\text { Govt health center } \\
\text { Dispensary . } \\
\text { Pvt hospital/clinic } \\
\text { Pharmacy/Chemist } \\
\text { TBA } \\
\text { HHW } \\
\text { Otherbalist }\end{array}$ \\
\hline & - Circle all mentioned. & \\
\hline
\end{tabular}

Check CI. If respondent has never been pregnant, go to $\mathrm{GI}$.

\begin{tabular}{|c|c|c|}
\hline F6 & $\begin{array}{l}\text { Has there been a time when you were pregnant that you } \\
\text { experienced bleeding in the first few months of the } \\
\text { pregnancy? } \\
\text { Kuna wakati wowote ukiwa mja mzito ambapo uliwahi kuvuja } \\
\text { damu katika miezi ya kwanza ya hiyo mimba? }\end{array}$ & 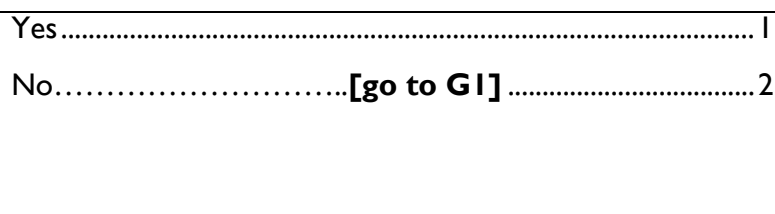 \\
\hline F7 & $\begin{array}{l}\text { In what year did this happen? } \\
\text { Jambo hili lilitendeka mwaka gani? }\end{array}$ & Year \\
\hline F8 & $\begin{array}{l}\text { During which month of the pregnancy did the bleeding } \\
\text { occur? } \\
\text { Kuvuja damu kulitendeka katika mwezi upi wa hiyo } \\
\text { mimba/uja uzito? } \\
\text { If bleeding happened during more than one } \\
\text { month, circle all mentioned. }\end{array}$ & 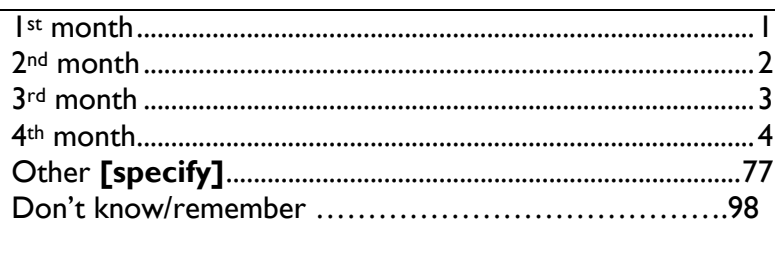 \\
\hline F9 & $\begin{array}{l}\text { In addition to the bleeding, what other kind of } \\
\text { complications did you experience at that time, if any? } \\
\text { Je, kando na kuvuja damu; ulipata shida gani zingine wakati } \\
\text { huo? }\end{array}$ & 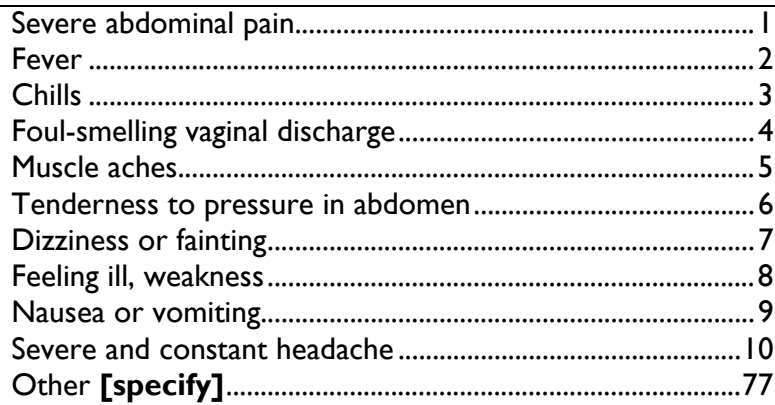 \\
\hline FIO & $\begin{array}{l}\text { Did you seek care for the bleeding and/or other } \\
\text { complications? } \\
\text { Je, ulitafuta kupata utunzi kwa sababu ya kuvuja damu nalau } \\
\text { shida zingine zozote? }\end{array}$ & Yes \\
\hline FII & $\begin{array}{l}\text { Where or from whom did you seek care? } \\
\text { Ulitafuta utunzi kutoka wapi au kwa nani? } \\
\text { Any other place? } \\
\text { - Circle all mentioned. }\end{array}$ & $\begin{array}{l}\text { Govt hospital/clinic } \\
\text { Govt health center } \\
\text { Dispensary } \\
\text { Pvt hospital/clinic } \\
\text { Pharmacy/Chemist } \\
\text { TBA }\end{array}$ \\
\hline & \multicolumn{2}{|l|}{ Check FI I. If F I I=9 ONLY, go to F30. } \\
\hline
\end{tabular}




\begin{tabular}{|c|c|c|}
\hline $\mathrm{FI2}$ & $\begin{array}{l}\text { How long did you have to wait before a provider saw } \\
\text { you? } \\
\text { Ulisubiri muda gani kabla ya kuhudumiwa? }\end{array}$ & 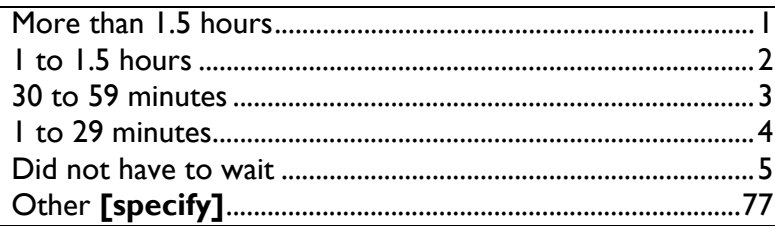 \\
\hline $\mathrm{FI3}$ & $\begin{array}{l}\text { Do you think there was enough privacy when you shared } \\
\text { your problem with the provider? } \\
\text { Je, unafikiri ulikuwa mahali pa sirilfaragha ya kutosha wakati } \\
\text { ulipokuwa ukimwelezea mhudumu shida zako? }\end{array}$ & Yes No \\
\hline $\mathrm{FI} 4$ & $\begin{array}{l}\text { What help/advice did you get from the provider? } \\
\text { Ulipata usaidizi/ushauri gani kutoka kwa mhudumu? } \\
\text { - Probe: 'Did they have to do something to } \\
\text { fix the bleeding and/or other problems?' } \\
\text { - Circle all mentioned. }\end{array}$ & $\begin{array}{l}\text { Underwent a surgical procedure } \\
\text { Hospitalization } \\
\text { Bed rest } \\
\text { Herbs/traditional medicines } \\
\text { Home remedies } \\
\text { Medications } \\
\text { Nutritional diet } \\
\text { Other [specify] }\end{array}$ \\
\hline FI5 & $\begin{array}{l}\text { Do you think the provider gave you enough time to } \\
\text { explain your health situation? } \\
\text { Je, unafikiria mhudumu alikupatia muda wa kutosha wa } \\
\text { kumwelezea kuhusu hali yako ya kiafya? }\end{array}$ & Yes No \\
\hline FI6 & $\begin{array}{l}\text { Did the provider clearly explain what health care services } \\
\text { he/she would provide? } \\
\text { Je, mhudumu alikuelezea kwa uwazi zile huduma za afya } \\
\text { ambazo angekupatia? }\end{array}$ & Yes ${ }^{2}$ \\
\hline FI7 & $\begin{array}{l}\text { Did you understand the explanation? } \\
\text { Je, ulielewa hayo maelezo? }\end{array}$ & 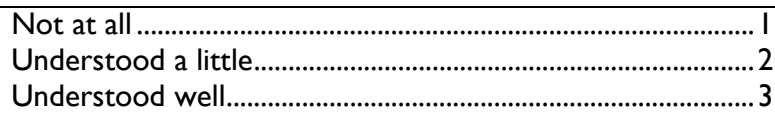 \\
\hline FI8 & $\begin{array}{l}\text { Did the provider offer you medication to help with pain? } \\
\text { Je, mhudumu alikupatia dawa za kupunguza uchungu? }\end{array}$ & Yes No \\
\hline FI9 & $\begin{array}{l}\text { What sort of information did the provider give you upon } \\
\text { discharge? } \\
\text { Je, muhudumu alikupatia habari gani alipokuruhusu kwenda } \\
\text { nyumbani? } \\
\text { - Circle all mentioned. }\end{array}$ & 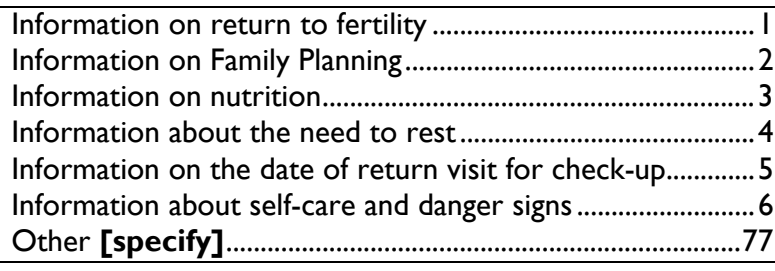 \\
\hline $\mathrm{F} 20$ & $\begin{array}{l}\text { Do you think you were treated well, poorly, or neither } \\
\text { well nor poorly by the provider? } \\
\text { Kwa maoni yako, mhudumu wako ulihudumiwa vizuri, vibaya } \\
\text { au si vizuri wala vibaya na? }\end{array}$ & 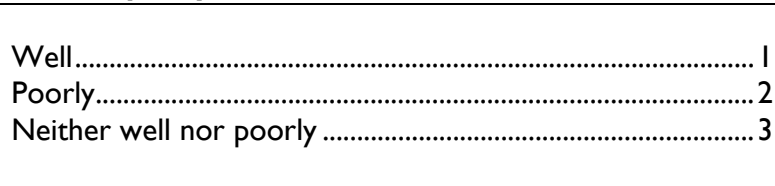 \\
\hline F2I & $\begin{array}{l}\text { During your visit to the place you went to for treatment, } \\
\text { would you say the other staff treated you very well, so- } \\
\text { so, poorly, or very poorly? } \\
\text { Wakati ulipotembelea mahali pahuduma, unaweza kusema } \\
\text { kuwa wafanyi kazi wale wengine walikuhudumia vizuri sana, } \\
\text { wastani, vibaya au vibaya sana? }\end{array}$ & 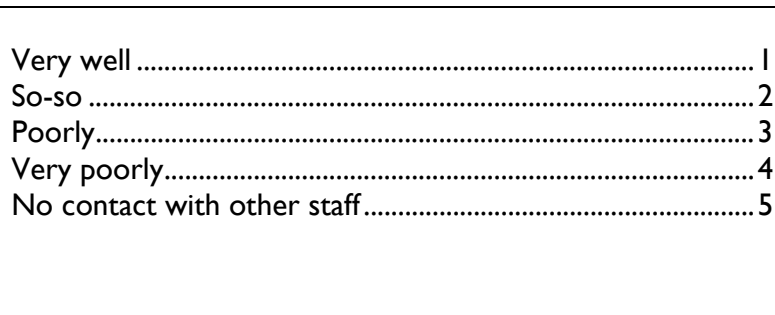 \\
\hline
\end{tabular}




\begin{tabular}{|c|c|c|}
\hline $\mathrm{F} 22$ & $\begin{array}{l}\text { Do you think in addressing your problem, the provider } \\
\text { was helpful, somewhat helpful, or not helpful at all? } \\
\text { Je, katika kushughulikia shida zako; unafikiria kuwa } \\
\text { mhudumu alikusaidia, alikusaidia kiasi ama hakukusaidia } \\
\text { kabisa? }\end{array}$ & 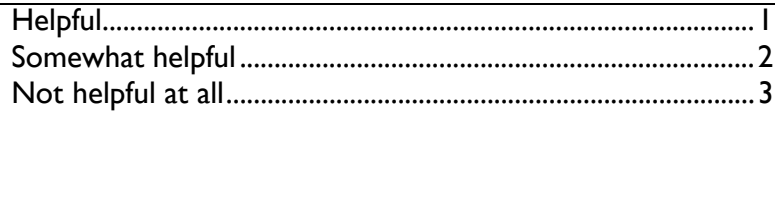 \\
\hline $\mathrm{F} 23$ & $\begin{array}{l}\text { Have you recommended this place to anybody else? } \\
\text { Je, umependekeza mahali hapa kwa mtu mwingine yoyote? }\end{array}$ & 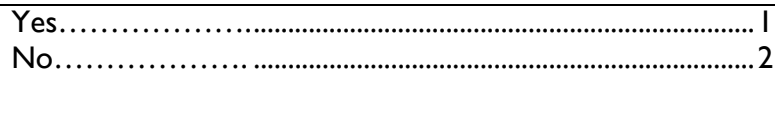 \\
\hline $\mathrm{F} 24$ & $\begin{array}{l}\text { Was this place located right in this community? } \\
\text { Je, mahali hapo palikuwa katika eneo la jamii hii? }\end{array}$ & 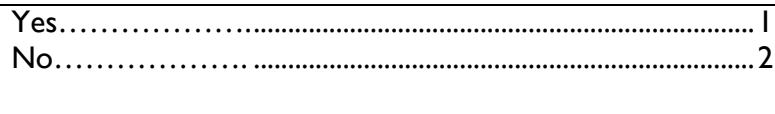 \\
\hline $\mathrm{F} 25$ & $\begin{array}{l}\text { Is it within walking distance, or would some kind of } \\
\text { transportation be needed to get there? } \\
\text { Je, ni mahali ambapo unaweza kutembea, au usafiri wa aina } \\
\text { fulani unahitajika ili uweze kufika hapo? }\end{array}$ & 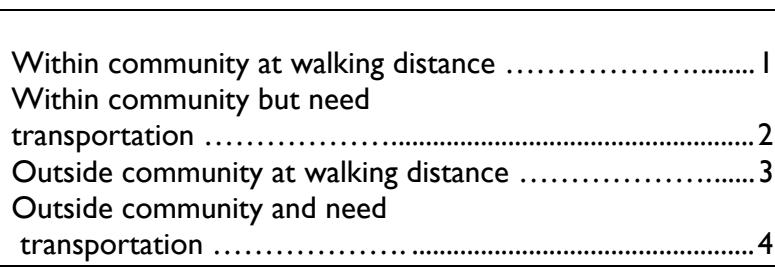 \\
\hline F26 & $\begin{array}{l}\text { How much time would you say it took you to reach this } \\
\text { place? } \\
\text { Ilikuchukua muda gani kufika mahali hapo? }\end{array}$ & 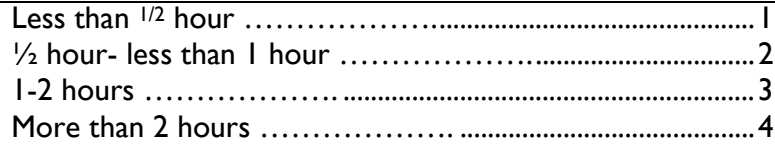 \\
\hline F27 & $\begin{array}{l}\text { How much did you spend for the travel cost in total? } \\
\text { Kwa ujumla, ilikugharimu kiasi kipi cha pesa kwa usafiri? }\end{array}$ & 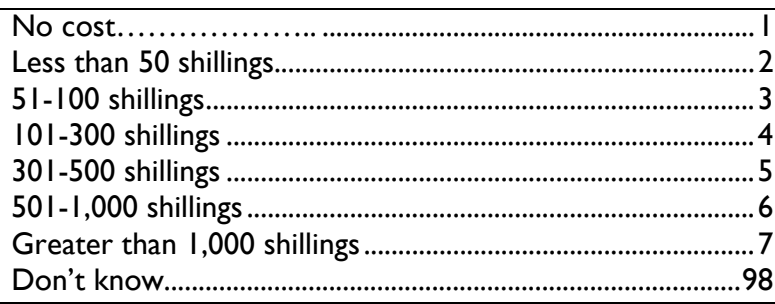 \\
\hline F28 & $\begin{array}{l}\text { How much did you have to pay for the services, including } \\
\text { drugs and supplies? } \\
\text { Ulilipia kiasi kipi cha pesa kwa huduma ilizo pata pamoja na } \\
\text { dawa na kadhalika? } \\
\text { Remember that you may have had to buy some } \\
\text { drugs/supplies outside the place you went to - please } \\
\text { include this in the total amount you spent. }\end{array}$ & 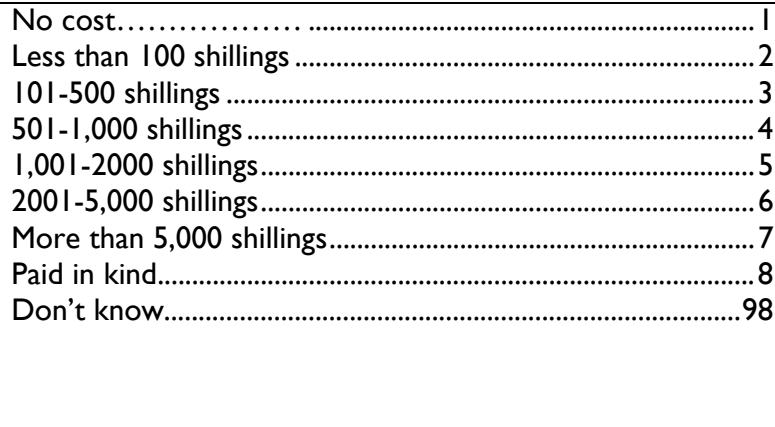 \\
\hline F29 & $\begin{array}{l}\text { Who paid? } \\
\text { Ni nani aligharamia/alilipia? } \\
\text { - Circle all mentioned. }\end{array}$ & 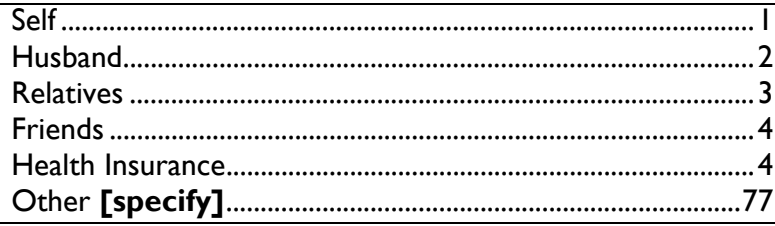 \\
\hline F30 & $\begin{array}{l}\text { During this time, did your husband/partner know that } \\
\text { you were experiencing complications? } \\
\text { Je, kwa wakati huo; mume/mpenzi wako alikuwa anajua } \\
\text { kwamba ulikuwa unapitia (umekumbwa na) matatizo/shida? }\end{array}$ & 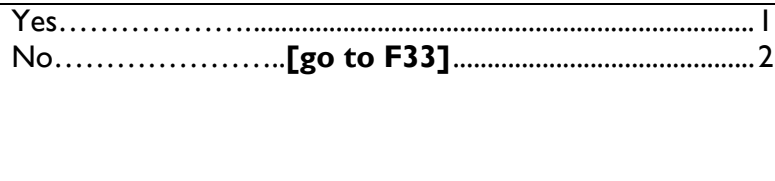 \\
\hline F3I & $\begin{array}{l}\text { Did you receive support and care from him? } \\
\text { Je, ulipata usaidizi na utunzi kutoka kwake? }\end{array}$ & Yes No \\
\hline
\end{tabular}




\begin{tabular}{|c|c|c|}
\hline$F 32$ & $\begin{array}{l}\text { In what way(s) did your husband/partner support or care } \\
\text { for you during this time? } \\
\text { Ni kwa njia gani/zipi ambazo mume/mpenzi wako alikusaidia } \\
\text { au kukupatia utunzi wakati huo? } \\
\text { - Circle all mentioned. }\end{array}$ & 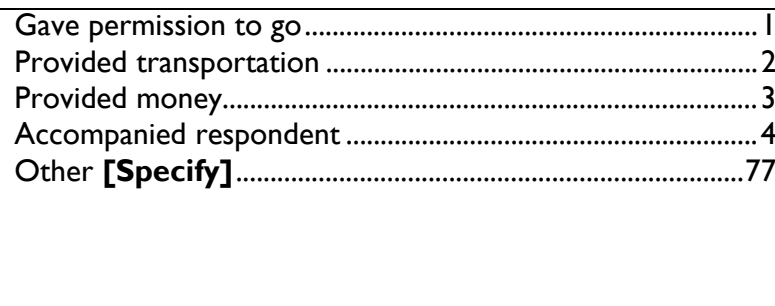 \\
\hline F33 & $\begin{array}{l}\text { Check previous question. If } \mathbf{F 3 2 = 4 , ~ a s k : ~} \\
\text { Who else went with you? } \\
\text { Mlienda/mliandamana na nani? } \\
\text { If F32=any other option, or if } \mathbf{F 3 2} \text { was skipped, } \\
\text { ask: } \\
\text { Who went with you (to see a provider)? } \\
\text { Mlienda/mliandamana na nani kuenda kumwona mhudumu? } \\
\text { - Circle all mentioned. }\end{array}$ & $\begin{array}{l}\text { No one } \\
\text { Husband/partner.1. } \\
\text { Mother-in-law } \\
\text { Mother. } \\
\text { Sister } \\
\text { Sister-in-law } \\
\text { Other relative } \\
\text { Friend/neighbor } \\
\text { Other [Specify] }\end{array}$ \\
\hline F34 & $\begin{array}{l}\text { During this time, did your in-laws know that you were } \\
\text { experiencing complications? } \\
\text { Je, kwa wakati huo; wakwe zako walijua kwamba ulikuwa } \\
\text { unapitia (umekumbwa na) matatizo/shida? }\end{array}$ & 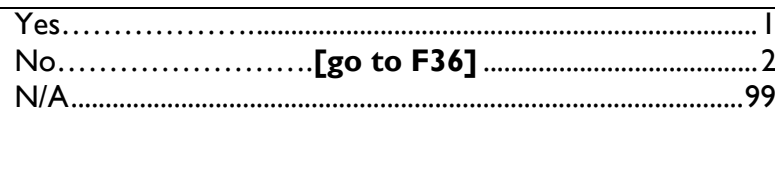 \\
\hline F35 & $\begin{array}{l}\text { Did you receive support and care from them? } \\
\text { Je, ulipata usaidizi na utunzi kutoka kwao? }\end{array}$ & Yes \\
\hline F36 & $\begin{array}{l}\text { During this time, did your parents know that you were } \\
\text { experiencing complications? } \\
\text { Je, kwa wakati huo; wazazi wako walijua kwamba ulikuwa } \\
\text { unapitia (umekumbwa na) matatizo/shida? }\end{array}$ & 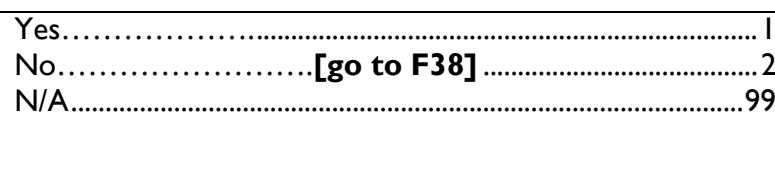 \\
\hline F37 & $\begin{array}{l}\text { Did you receive support and care from them? } \\
\text { Je, ulipata usaidizi na utunzi kutoka kwao? }\end{array}$ & Yes \\
\hline F38 & $\begin{array}{l}\text { Did the complications resolve? } \\
\text { Je, hizo shida zilitatuliwa? }\end{array}$ & 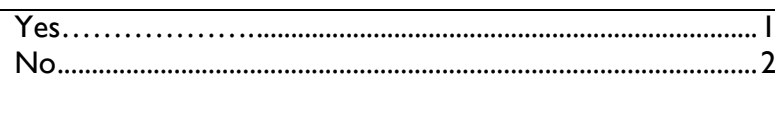 \\
\hline F39 & $\begin{array}{l}\text { Did you have any more complications in the first half of } \\
\text { your pregnancy? } \\
\text { Je, ulipata shida zingine zozote katika miezi ya kwanza nusu } \\
\text { ya uja uzito wako? }\end{array}$ & Yes \\
\hline F40 & $\begin{array}{l}\text { Did the pregnancy end? } \\
\text { Je,ulipoteza hiyo mimba? }\end{array}$ & Yes. \\
\hline F4I & $\begin{array}{l}\text { At the time you discovered you were pregnant (with this } \\
\text { particular pregnancy), did you want to get pregnant then? } \\
\text { Je, wakati ulipogundua kuwa wewe ni mja mzito (na hiyo } \\
\text { mimba hasa), ulikuwa ukitaka kushika mimba wakati huo? }\end{array}$ & 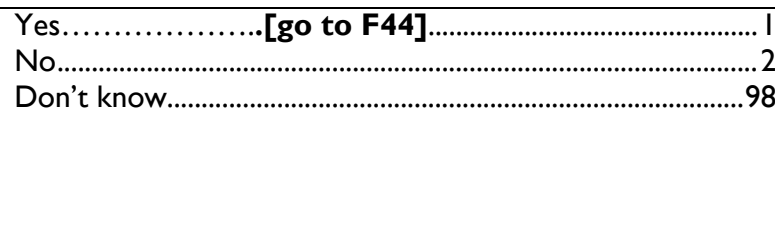 \\
\hline
\end{tabular}




\begin{tabular}{|c|c|c|}
\hline F42 & $\begin{array}{l}\text { Were you using a family planning method at the time you } \\
\text { discovered you were pregnant? } \\
\text { Je, ulikuwa ukitumia njia ya kupanga uzazi wakati } \\
\text { ulipogundua kuwa wewe ni mja mzito? }\end{array}$ & 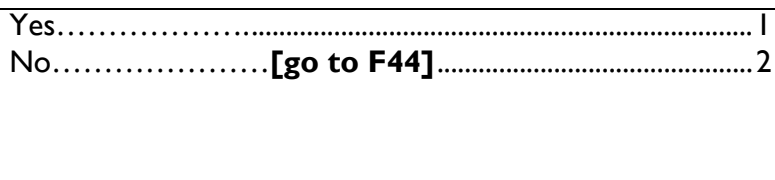 \\
\hline F43 & $\begin{array}{l}\text { What is the reason that best explains how the pregnancy } \\
\text { occurred while a family planning method was being used? } \\
\text { Ni sababu gani ambayo inafafanua kikamilifu/vizuri zaidi jinsi } \\
\text { mimba ilitokea, ilhali njia ya kupanga uzazi ilikuwa ikitumika? }\end{array}$ & 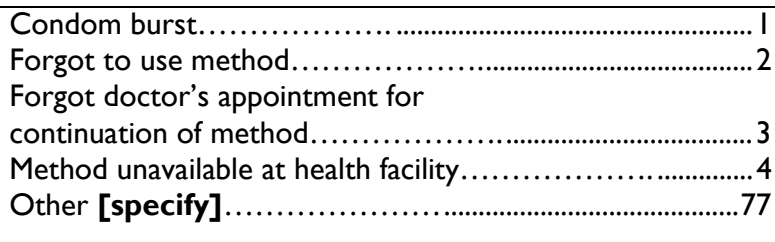 \\
\hline F44 & $\begin{array}{l}\text { Immediately after the pregnancy ended/after the delivery, } \\
\text { did anyone talk to you about how to avoid getting } \\
\text { pregnant again? } \\
\text { Punde tu baada yakupoteza mimba / kujifungua, kuna mtu } \\
\text { yeyote ambaye alikuzungumzia kuhusu jinsi ya kuepuka } \\
\text { kushika mimba tena? } \\
\text { Anyone else? } \\
\text { Circle all mentioned. }\end{array}$ & 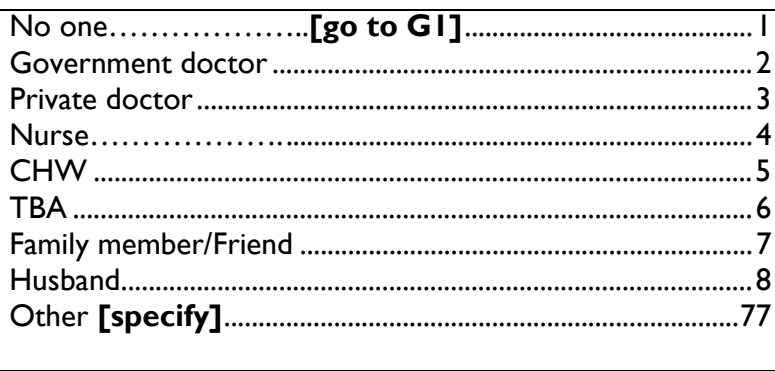 \\
\hline F45 & $\begin{array}{l}\text { Did you seek the advice or they gave it on their own? } \\
\text { Je, ulitafuta huo ushauri au walikupatia tu kwa hiari yao? }\end{array}$ & 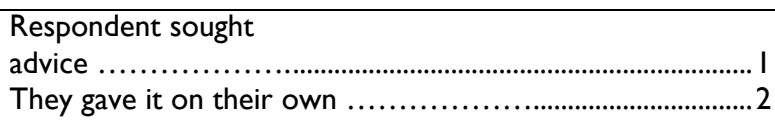 \\
\hline F46 & $\begin{array}{l}\text { Did you feel they were pressuring you to use a particular } \\
\text { method? } \\
\text { Je, ulihisi/ulifikiria kwamba walikuwa wanakushurutisha } \\
\text { kutumia njia fulani? }\end{array}$ & 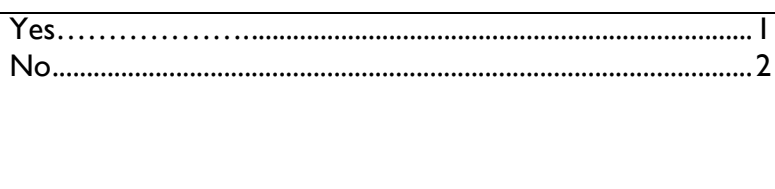 \\
\hline F47 & $\begin{array}{l}\text { Which methods did they discuss with you? } \\
\text { Ni njia zipi walizozungumzia na wewe? } \\
\text { - Circle all mentioned. }\end{array}$ & $\begin{array}{l}\text { Pills } \\
\text { IUD (Copper T) } \\
\text { Injection } \\
\text { Condom } \\
\text { Implants } \\
\text { Fertility awareness method } \\
\text { Withdrawal } \\
\text { Female sterilization } \\
\text { Male sterilization } \\
\text { Emergency contraceptive } \\
\text { Lactational amen. method } \\
\text { Standard days method } \\
\text { Other [Specify] }\end{array}$ \\
\hline F48 & $\begin{array}{l}\text { Did you accept a family planning method(s)? } \\
\text { Je, ulikubali njia yalza kupanga uzazi? }\end{array}$ & Yes \\
\hline F49 & $\begin{array}{l}\text { Which method(s) did you accept? } \\
\text { Ni njia gani/zipi ulizozikubali? } \\
\text { - Circle all mentioned. }\end{array}$ & $\begin{array}{l}\text { Pills } \\
\text { IUD (Copper T) } \\
\text { Injection } \\
\text { Condom } \\
\text { Implants } \\
\text { Fertility awareness method } \\
\text { Withdrawal } \\
\text { Female sterilization } \\
\text { Male sterilization } \\
\text { Emergency contraceptive } \\
\text { Lactational amen. method } \\
\text { Standard days method } \\
\text { Other [Specify] }\end{array}$ \\
\hline
\end{tabular}




\begin{tabular}{|c|c|c|}
\hline F50 & $\begin{array}{l}\text { Where or from whom did you obtain this family planning } \\
\text { method(s)? } \\
\text { Je, ulipata njia hii/hizi ya kupanga uzazi; kutoka wapi au kwa } \\
\text { nani? }\end{array}$ & $\begin{array}{l}\text { Govt hospital/clinic } \\
\text { Govt health center.1.1.1. } \\
\text { Dispensary } \\
\text { Pvt hospital/clinic } \\
\text { Pharmacy/Chemist }\end{array}$ \\
\hline \multirow[t]{2}{*}{ F5I } & $\begin{array}{l}\text { For how long did you use that/those methods after the } \\
\text { pregnancy? } \\
\text { Baada ya mimba, ulitumia hiyo/hizo njia kwa muda gani? }\end{array}$ & 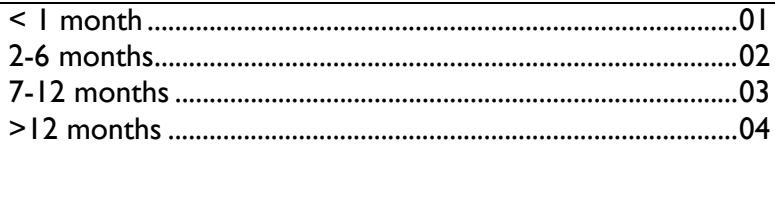 \\
\hline & \multicolumn{2}{|l|}{ Go to G I } \\
\hline F52 & $\begin{array}{l}\text { What were the barriers that prevented you from } \\
\text { accepting any family planning method? } \\
\text { Ni vizuizi/vikwazo vipi ambavyo vilikuzuia usiweze kukubali } \\
\text { njia yoyote ya kupanga uzazi? }\end{array}$ & 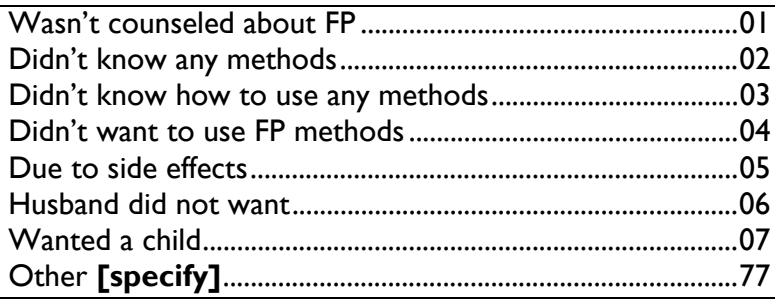 \\
\hline \multicolumn{3}{|c|}{ Go to G I } \\
\hline F53 & $\begin{array}{l}\text { What is the reason why you did not seek care for the } \\
\text { bleeding and/or other complications? } \\
\text { Ni kwa sababu gani haukutafuta kupata utunzi kutokana na } \\
\text { kuvuja damu nalau shida zingine? }\end{array}$ & 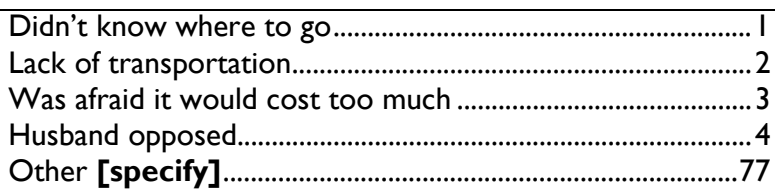 \\
\hline
\end{tabular}




\section{SECTION G: EXPOSURE TO COMMUNITY INTERVENTIONS}

Now, I would like to ask you about some activities that may be going on in this community, and about how this community members work together.

Sasa ningependa kukuuliza kuhusu miradi inayo endelea katika jamii hii.

\begin{tabular}{|c|c|c|c|c|c|}
\hline Q No. & Questions and filters & \multicolumn{4}{|c|}{ Responses and codes } \\
\hline GI & $\begin{array}{l}\text { When you think about this community, which } \\
\text { group would you say is the most active in solving } \\
\text { the community's health-related problems? } \\
\text { Katika jamii hii, ni akina nani ambao hufanya kazi } \\
\text { sanalkwa wingi zaidi katika kusuluhishalkutatua shida } \\
\text { za kiafya? } \\
\text { Read out options. } \\
\text { Circle only one. }\end{array}$ & \multicolumn{4}{|c|}{ 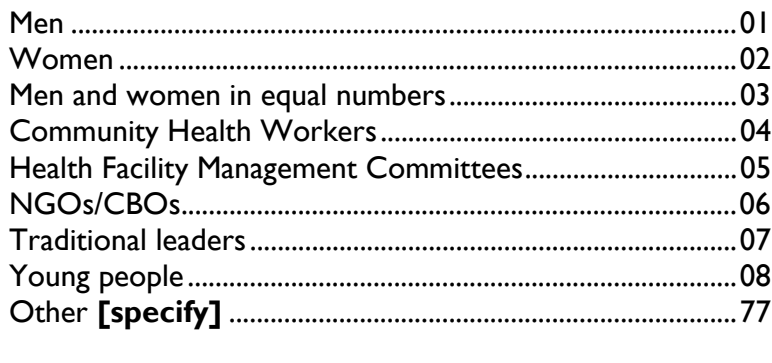 } \\
\hline G2 & $\begin{array}{l}\text { When this community has a health-related } \\
\text { problem that needs to be solved, how well do the } \\
\text { community members work together to solve it? } \\
\text { Je, wakati jamii hii ina shida ya kiafya inayohitaji } \\
\text { kusuluhishwa; watu katika jamii huweza kufanya kazi } \\
\text { pamoja kwa njia gani? }\end{array}$ & \multicolumn{4}{|c|}{ 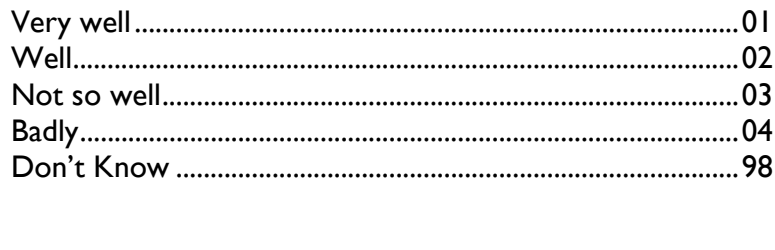 } \\
\hline G3 & $\begin{array}{l}\text { In the last year, has this community's ability to } \\
\text { solve its health-related problems improved, } \\
\text { worsened, or stayed about the same? } \\
\text { Je, katika muda wa mwaka mmoja ambao umepita; } \\
\text { uwezo wa jamii hii wa kutatua shida za kiafya } \\
\text { umeimarika/umeboreshwa, umekuwa mbaya zaidi au } \\
\text { umebakia tu vile ulivyokuwa? }\end{array}$ & \multicolumn{4}{|c|}{$\begin{array}{l}\text { Improved } \\
\text { Worsened } \\
\text { Stayed about the same } \\
\text { Don't Know }\end{array}$} \\
\hline \multirow[t]{4}{*}{ G4 } & \multirow{2}{*}{$\begin{array}{l}\text { To what extent do members of this community } \\
\text { participate ...: } \\
\text { Watu katika jamii hii hujihusisha kwa kiwango } \\
\text { kipi/gani...: } \\
\qquad \begin{array}{l}\text { a. in solving problems at the health } \\
\text { clinic/dispensary? } \\
\text { kutatua shida katika kituo cha } \\
\text { afyalzahanati? }\end{array}\end{array}$} & Large extent & Small extent & No extent & N/A \\
\hline & & I & 2 & 3 & 99 \\
\hline & $\begin{array}{l}\text { b. in community projects? } \\
\text { katika utaratibu wa kuleta jamii kushirikiana } \\
\text { katika miradi? }\end{array}$ & I & 2 & 3 & \\
\hline & $\begin{array}{l}\text { c. in addressing the problem that some } \\
\text { women have with bleeding in the first } \\
\text { half of pregnancy? } \\
\text { katika kushughulikia kuvuja damu katika } \\
\text { miezi ya kwanza nusu ya uja uzito? }\end{array}$ & 1 & 2 & 3 & \\
\hline
\end{tabular}




\begin{tabular}{|c|c|c|}
\hline Q No. & Questions and filters & Responses and codes \\
\hline G5 & $\begin{array}{l}\text { Is there a forum where community members can } \\
\text { discuss their health-related concerns? } \\
\text { Je, kuna mpangilio wa kukutana ambapo watu katika } \\
\text { jamii hii wanaweza kuzungumzia juu ya mambo } \\
\text { yanayo wahusu shida zao za kiafya? }\end{array}$ & 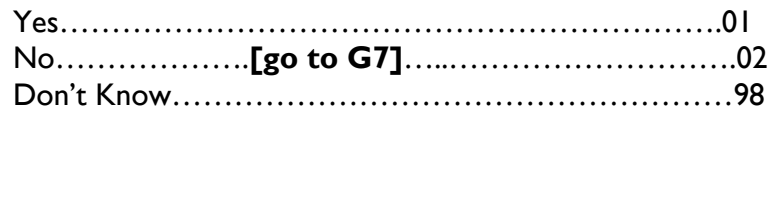 \\
\hline G6 & $\begin{array}{l}\text { Where can they discuss their health-related } \\
\text { concerns? } \\
\text { Any other forum? } \\
\text { Wanaweza kuzungumzia juu ya mambo } \\
\text { yanayowahusu kiafya kutoka wapi? Kuna mahali } \\
\text { pengine? } \\
\text { Circle all mentioned. }\end{array}$ & 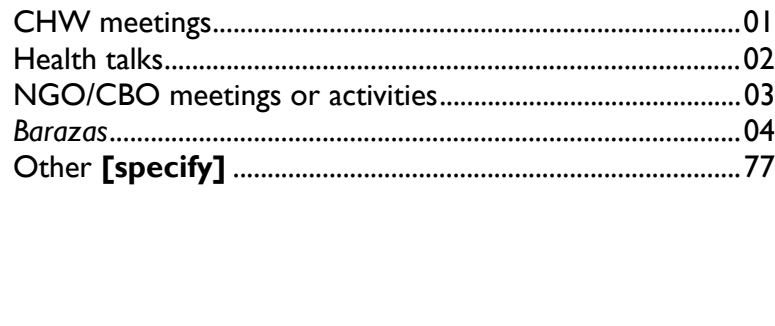 \\
\hline G7 & $\begin{array}{l}\text { How much do people in this community discuss } \\
\text { their health-related concerns in public meetings? } \\
\text { Je, ni kwa kiwango gani; watu katika jamii hii } \\
\text { huzungumzia mambo yanayowahusu kiafya katika } \\
\text { mikutano ya hadhara? }\end{array}$ & 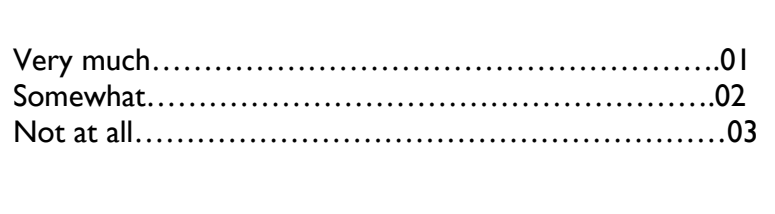 \\
\hline G8 & $\begin{array}{l}\text { Over the past one year in this community, are } \\
\text { there any health issues that people formerly were } \\
\text { unable/reluctant to discuss in public, but are now } \\
\text { able to discuss? } \\
\text { Katika muda wa mwaka mmoja ambao umepita; kuna } \\
\text { mambo yoyote ya kiafya ambayo watu hawangeweza } \\
\text { au hawakutaka kuyazungumzia hadharani/waziwazi, } \\
\text { lakini sasa wanaweza kuyazungumzia? }\end{array}$ & 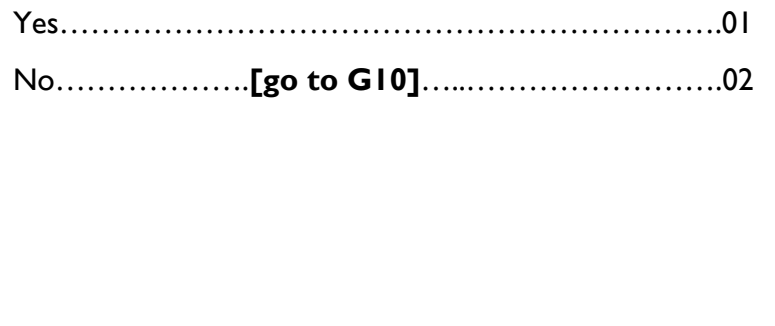 \\
\hline G9 & $\begin{array}{l}\text { What sensitive health issues do people now discuss } \\
\text { in public? } \\
\text { Je, ni mambo gani nyeti ya kiafya ambayo watu sasa } \\
\text { wanaweza kuyazungumzia hadharani? } \\
\text { - Listen to what people say first and } \\
\text { write down. } \\
\text { - Then, probe on: family planning, } \\
\text { bleeding in the first half of } \\
\text { pregnancy, unplanned pregnancy, } \\
\text { and circle all mentioned. }\end{array}$ & Unplanned pregnancy planning \\
\hline GI0 & $\begin{array}{l}\text { Do you know any of the community health } \\
\text { extension workers (CHEWs) or the community } \\
\text { health workers (CHWs) in this community that } \\
\text { meet to discuss how community health can be } \\
\text { improved? } \\
\text { Je, unamfahamu yeyote kati ya wale wahudumu wa } \\
\text { afya wa kijamii (CHEWs, CHWs) katika jamii hii } \\
\text { ambao hukutana na kujadili jinsi afya ya jamii inaweza } \\
\text { kuboreshwa? }\end{array}$ & 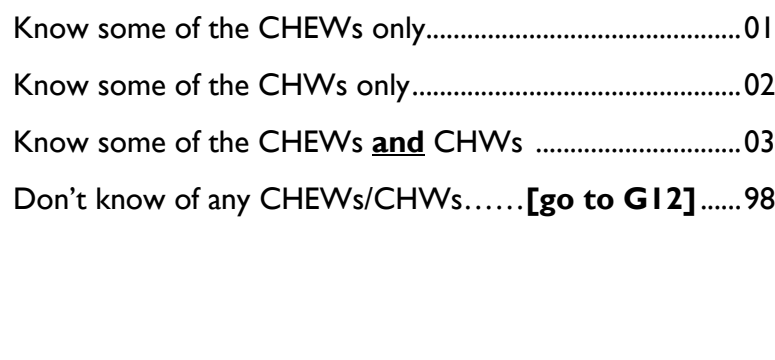 \\
\hline
\end{tabular}




\begin{tabular}{|c|c|c|}
\hline Q No. & Questions and filters & Responses and codes \\
\hline GII & $\begin{array}{l}\text { Has the role of } \mathrm{CHWs} \text { increased, decreased, or } \\
\text { remained the same in this community over the past } \\
\text { year? }\end{array}$ & $\begin{array}{l}\text { Increased } \\
\text { Decreased } \\
\text { Remained the Same } \\
\text { Don't know }\end{array}$ \\
\hline GI2 & $\begin{array}{l}\text { Are you aware of any NGOs or community groups } \\
\text { working in this community? } \\
\text { Je, unafahamu mashirika yoyote ya kijamii au } \\
\text { mashirika yasiyo ya serikali [NGO]/yaliyo katika jamii } \\
\text { hii? } \\
\text { Probe: 'Any women's groups, men's groups, } \\
\text { etc.? }\end{array}$ & Yes \\
\hline GI3 & $\begin{array}{l}\text { What health-related activities have the } \\
\text { NGOs/community groups conducted in this } \\
\text { community over the past year? Is there anything } \\
\text { else? } \\
\text { Je, nishughuli zipi za kiafya zimetekelezwa na } \\
\text { mashirika haya kwa muda wa mwaka mmoja ambao } \\
\text { umepita? Kuna zingine? }\end{array}$ & 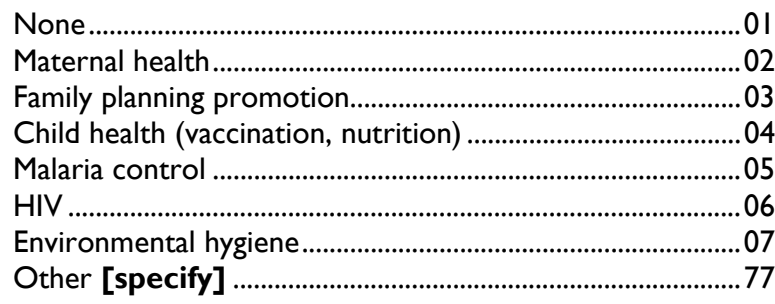 \\
\hline GI4 & $\begin{array}{l}\text { In this community, has the role of } \\
\text { NGOs/community groups increased, decreased, or } \\
\text { remained the same over the past year? } \\
\text { Je, katika jamii hii jukumu la mashirika haya } \\
\text { limeongezeka, limepunguka au limebakia tu vile } \\
\text { lilivyokuwa katika muda wa mwaka mmoja ambao } \\
\text { umepita? }\end{array}$ & $\begin{array}{l}\text { Increased } \\
\text { Decreased } \\
\text { Remained the Same } \\
\text { Don't know }\end{array}$ \\
\hline GI5 & $\begin{array}{l}\text { Have you participated in any NGO/community } \\
\text { group meeting or activity focused on bleeding in } \\
\text { the first half of pregnancy in the past year? } \\
\text { Je, katika muda wa mwaka mmoja ambao umepita; } \\
\text { umeshiriki katika shughuli yoyote ya shirika la } \\
\text { kijamii/shirika lisilo la serikali/mhudumu wa afya ya } \\
\text { kijamii iliyolenga kuvuja damu katika miezi ya kwanza } \\
\text { nusu ya uja uzito? }\end{array}$ & 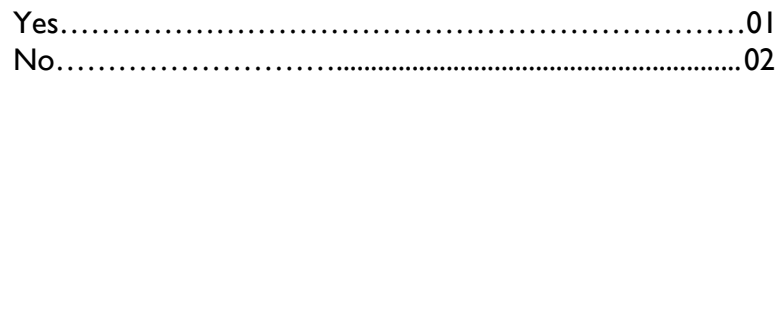 \\
\hline GI6 & $\begin{array}{l}\text { Have you participated in any } \mathrm{CHW} \text { meeting or } \\
\text { activity focused on bleeding in the first half of } \\
\text { pregnancy in the past year? }\end{array}$ & 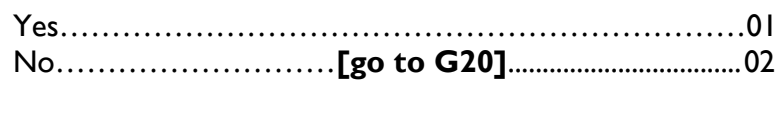 \\
\hline GI7 & $\begin{array}{l}\text { About how many of such health-related } \\
\text { meetings/activities on bleeding in the first half of } \\
\text { pregnancy have you participated in over the past } \\
\text { year? } \\
\text { Umeshiriki katika mikutano au shughuli kama ngapi } \\
\text { hivi zinazohusu afya katika muda wa mwaka mmoja } \\
\text { ambao umepita? }\end{array}$ & $\begin{array}{l}\text { None } \\
\text { One } \\
\text { Two or Three } \\
\text { Four to Nine } \\
\text { Ten or above. }\end{array}$ \\
\hline
\end{tabular}




\begin{tabular}{|c|c|c|}
\hline Q No. & Questions and filters & Responses and codes \\
\hline GI8 & $\begin{array}{l}\text { Do you think these health-related } \\
\text { meetings/activities have resulted in improvements } \\
\text { in this community? } \\
\text { Je, unafikiria kwamba hizi shughuli au mikutano za } \\
\text { kiafya zimeleta maendeleo yoyote katika jamii hii? }\end{array}$ & 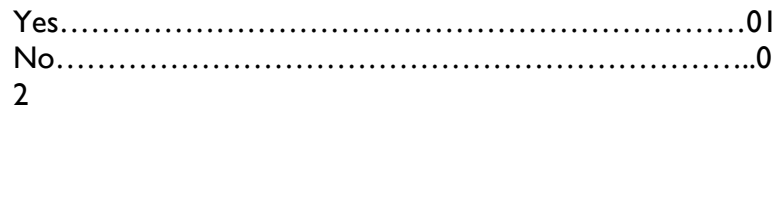 \\
\hline GI9 & $\begin{array}{l}\text { Do you think these meetings/activities have } \\
\text { resulted in improvements in your health } \\
\text { center/dispensary? } \\
\text { Je, unafikiria kwamba hizi shughuli au mikutano ya } \\
\text { kiafya imeleta maendeleo yoyote katika kituo chenu } \\
\text { cha afya/zahanati? }\end{array}$ & 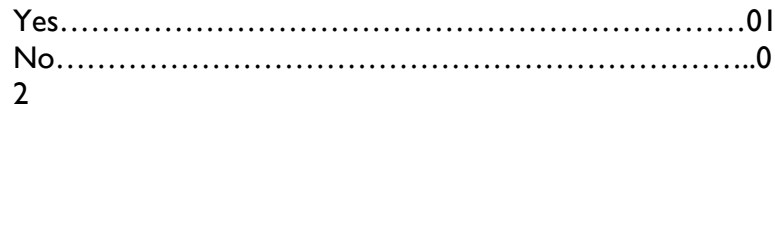 \\
\hline G20 & $\begin{array}{l}\text { Do you think that knowledge has increased in this } \\
\text { community about complications in pregnancy such } \\
\text { as bleeding in the first half of pregnancy over the } \\
\text { past year? } \\
\text { Je, unafikiria kwamba elimu kuhusu shida katika uja } \\
\text { uzito kama vile kuvuja damu katika miezi ya kwanza } \\
\text { nusu ya uja uzito; imeongezeka katika jamii hii kwa } \\
\text { muda wa mwaka mmoja ambao umepita? }\end{array}$ & $\begin{array}{l}\text { Yol } \\
2 \\
\text { Don't know }\end{array}$ \\
\hline G2I & $\begin{array}{l}\text { Over the past year, do you think that community } \\
\text { action has increased to assist women with seeking } \\
\text { help when bleeding in pregnancy occurs? } \\
\text { Katika muda wa mwaka mmoja ambao umepita, } \\
\text { unafikiria kwamba juhudi za jamii zimeongezeka } \\
\text { katika kusaidia wanawake ambao wanatafuta usaidizi; } \\
\text { wakati kuvuja damu katika uja uzito inapotokea? }\end{array}$ & $\begin{array}{l}\text { Yes } \\
\text { No } \\
\text { Don't know }\end{array}$ \\
\hline $\mathrm{G} 22$ & $\begin{array}{l}\text { What means of transportation has this community } \\
\text { set aside to take its sick members, including } \\
\text { pregnant women, to the hospital in an emergency? } \\
\text { Katika jamii hii, kuna njia yoyote ya kusafirisha } \\
\text { wagonjwa; wakiwemo akina mama waja wazito } \\
\text { kwenye hospitali wakati wa haja ya dharura? }\end{array}$ & $\begin{array}{l}\text { None } \\
\text { Health facility sends ambulance } \\
\text { Community taxi } \\
\text { Community motorcycle }\end{array}$ \\
\hline G23 & $\begin{array}{l}\text { Which of the following media do people in this } \\
\text { community get their health information from? } \\
\text { Ni vyombo vipi vya habari, kati ya hizi; ambavyo } \\
\text { huwapatia habari kuhusu afya katika jamii hii? } \\
\text { - Probe: Radio? TV? Newspapers? } \\
\text { Brochures? Others? } \\
\text { - Circle all mentioned. }\end{array}$ & 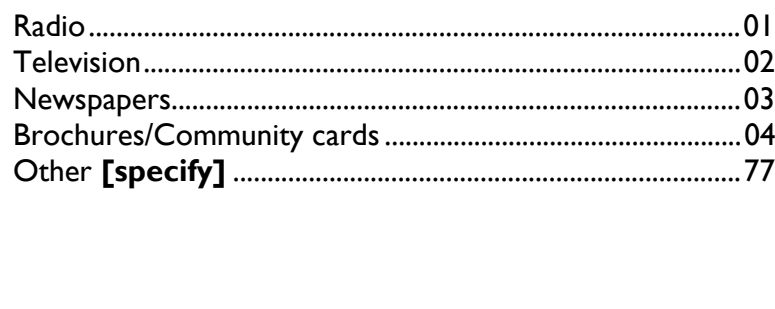 \\
\hline G24 & $\begin{array}{l}\text { Are you aware of any information campaign in this } \\
\text { community about health care for women who are } \\
\text { experiencing bleeding in the first half of pregnancy? } \\
\text { Je, unafahamu kuhusu kampeini zozote za kuelimisha } \\
\text { watu katika jamii hii kuhusu utunzi wa kiafya kwa } \\
\text { wanawake ambao wanavuja damu katika miezi ya } \\
\text { kwanza nusu ya uja uzito? }\end{array}$ & 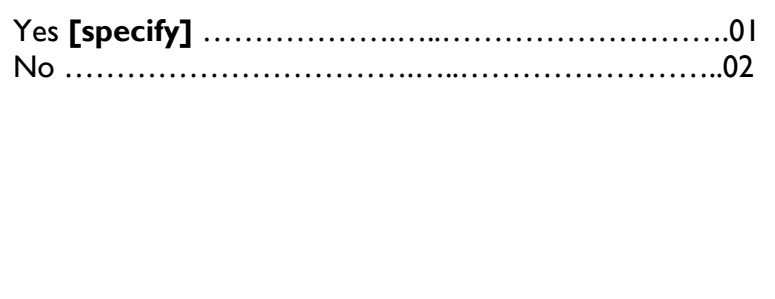 \\
\hline
\end{tabular}




\section{CONCLUSION}

We have now come to the end of the interview. Thank you very much for taking the time to answer our questions. Please be assured that the information you have provided will only be used for research at the Population Council. The answers you have given will be very helpful in improving services for women in communities like this one that experience bleeding in the early stages of pregnancy.

G25 I have asked you a lot of questions. Is there any question I can answer for you? Nimekuuliza maswahili mengi. Kuna swali lolote ambalo ungependa nikujibu?

Write down question and provide response. 


\title{
Appendix B: Facility Assessment Tool
}

\author{
Facility Assessment Tool \\ Evaluation of the Replication of the Community Post-Abortion Care Model in \\ Kenya \\ Population Council
}

GREETING: Good morning. My name is , and I work for the Population Council. We are currently doing a study on post-abortion care in Naivasha District and the kind of services that are available for this kind of care. This is not an evaluation of this facility or of the people who give us this information. We are visiting the health facilities which serve the catchment areas around most of the $\mathrm{MOH}$ community units in Naivasha, and all the information you give me will be confidential. No one will know what you said. The research we are conducting will be used to improve postabortion care services and we have sought permission from the district health authorities to carry out this study. Are you willing to assist?

\section{Facility identification}

\begin{tabular}{|c|c|c|c|}
\hline No. & Questions & \multicolumn{2}{|l|}{ Coding Categories } \\
\hline I.I & Date of observations & \multicolumn{2}{|l|}{$\overline{\text { (Dayl }}^{\prime} \overline{\text { Month } /}{ }^{\prime} \overline{\text { Year) }}$} \\
\hline 1.2 & Community Unit & & \\
\hline 1.3 & Facility name & & \\
\hline \multirow[t]{7}{*}{1.4} & \multirow[t]{7}{*}{ Type of facility } & Hospital & I \\
\hline & & $\begin{array}{l}\text { Health center with maternity } \\
\text { ward }\end{array}$ & 2 \\
\hline & & $\begin{array}{l}\text { Health center without maternity } \\
\text { ward }\end{array}$ & 3 \\
\hline & & Health post with maternity ward & 4 \\
\hline & & $\begin{array}{l}\text { Health post without maternity } \\
\text { ward }\end{array}$ & 5 \\
\hline & & Dispensary & 6 \\
\hline & & Other: & 77 \\
\hline \multirow[t]{4}{*}{1.5} & \multirow[t]{4}{*}{ Result of the inventory } & Complete & $\mathrm{I}$ \\
\hline & & Incomplete & 2 \\
\hline & & Refused & 3 \\
\hline & & Other: & 77 \\
\hline
\end{tabular}


2. Description of the service area

\begin{tabular}{|l|l|l|}
\hline No. & Questions & Coding Categories \\
\hline 2.1 & Catchment Population & \\
\hline 2.2 & $\begin{array}{l}\text { Number of women in reproductive } \\
\text { age }\end{array}$ & \\
\hline
\end{tabular}

\section{Hours of operation}

\begin{tabular}{|c|c|c|c|}
\hline No. & Question & Coding Categories & \\
\hline 3.1 & $\begin{array}{l}\text { Routinely, how many days per week is the facility } \\
\text { open? }\end{array}$ & Days: & \\
\hline 3.2 & $\begin{array}{l}\text { What are the opening and closing hours at this } \\
\text { facility? }\end{array}$ & $\begin{array}{l}\text { Opening time } \\
\text { Closing time } \\
\text { Minutes }) \\
\text { Open 24 hours? Y Y }\end{array}$ & \\
\hline 3.3 & Is this facility open on weekends? & \begin{tabular}{|l|} 
Yes \\
No
\end{tabular} & $\begin{array}{l}1 \\
2 \\
3.5\end{array}$ \\
\hline 3.4 & $\begin{array}{l}\text { What are the opening and closing hours at this } \\
\text { facility on weekends? }\end{array}$ & $\begin{array}{l}\text { Opening time } \\
\text { Closing time } \\
\text { Minutes })\end{array}$ & \\
\hline 3.5 & Does this facility provide PAC services? & \begin{tabular}{|l|} 
Yes \\
No
\end{tabular} & $\begin{array}{l}1 \\
2 \\
3.7\end{array}$ \\
\hline 3.6 & Does the facility provide PAC 24 hours a day? & \begin{tabular}{|l|} 
Yes \\
No
\end{tabular} & $\begin{array}{l}1 \\
2\end{array}$ \\
\hline 3.7 & $\begin{array}{l}\text { Is there a nurse or clinical officer present at the } \\
\text { facility at all times? ( } 24 \text { hours/day) }\end{array}$ & \begin{tabular}{|l|} 
Yes \\
No
\end{tabular} & $\frac{1}{2}$ \\
\hline 3.8 & $\begin{array}{l}\text { Is there a nurse or clinical officer available on call at } \\
\text { all times after hours? }\end{array}$ & \begin{tabular}{|l|} 
Yes \\
No
\end{tabular} & $\begin{array}{l}1 \\
2\end{array}$ \\
\hline
\end{tabular}




\section{Services available/Staff}

\begin{tabular}{|c|c|c|c|c|}
\hline \multirow{2}{*}{\begin{tabular}{|l|} 
No. \\
4.1
\end{tabular}} & \multirow{2}{*}{\begin{tabular}{|l} 
Questions \\
Do you have staff shortages in (read I to 2) services?
\end{tabular}} & \multicolumn{3}{|c|}{ Coding Categories } \\
\hline & & Yes & No & $\mathrm{N} / \mathrm{A}$ \\
\hline & I) $\mathrm{PAC}$ & I & 2 & 99 \\
\hline & 2) FP & 1 & 2 & \\
\hline \multirow[t]{11}{*}{4.2} & \multirow[t]{11}{*}{ What types of staff shortages are most critical? } & \multicolumn{2}{|c|}{ Medical specialists } & I \\
\hline & & \multicolumn{2}{|c|}{ General practitioners } & 2 \\
\hline & & \multicolumn{2}{|c|}{ Medical residents } & 3 \\
\hline & & \multicolumn{2}{|c|}{ Medical interns } & 4 \\
\hline & & \multicolumn{2}{|c|}{ Clinical officer } & 5 \\
\hline & & \multicolumn{2}{|c|}{ Trained midwives } & 6 \\
\hline & & \multicolumn{2}{|c|}{ Registered nurse } & 7 \\
\hline & & \multicolumn{2}{|c|}{ Enrolled nurse } & 8 \\
\hline & & \multicolumn{2}{|c|}{ Nursing student } & 9 \\
\hline & & \multicolumn{2}{|c|}{ Social worker } & 10 \\
\hline & & \multicolumn{2}{|l|}{ Other: } & 77 \\
\hline
\end{tabular}

\section{General infrastructure of the facility}

\begin{tabular}{|c|c|c|c|}
\hline \multirow{2}{*}{\begin{tabular}{|l} 
No. \\
5.1
\end{tabular}} & \multirow{2}{*}{$\begin{array}{l}\text { Questions } \\
\text { Interviewer: Observe the conditions and infrastructure in the facility and } \\
\text { mark whether it has the following. }\end{array}$} & \multicolumn{2}{|c|}{ Coding Categories } \\
\hline & & Yes & No \\
\hline & I) Piped running water & I & 2 \\
\hline & 2) Electricity & I & 2 \\
\hline & 3) Working latrines/toilets for clients & 1 & 2 \\
\hline & 4) Working phone/short wave radio & $\mathrm{I}$ & 2 \\
\hline & $\begin{array}{l}\text { 5) Transport vehicle in working order or standing arrangements for } \\
\text { transport in the case of emergencies }\end{array}$ & $\mathrm{I}$ & 2 \\
\hline & $\begin{array}{l}\text { 6) Clean facilities (e.g., the floors are swept, there is no dust in the } \\
\text { desks) }\end{array}$ & $\mathrm{I}$ & 2 \\
\hline & 7) Enough chairs or benches in waiting areas & I & 2 \\
\hline & $\begin{array}{l}\text { 8) Waiting area for clients where they are protected from the sun } \\
\text { and rain }\end{array}$ & $\mathrm{I}$ & 2 \\
\hline
\end{tabular}

Interviewer: Check 3.5. If this facility does not offer PAC services, go to 6.2 
6. Organization of PAC services

\begin{tabular}{|c|c|c|c|c|c|}
\hline \multirow{5}{*}{\begin{tabular}{|l|} 
No. \\
6.1
\end{tabular}} & \multirow{5}{*}{$\begin{array}{l}\text { Questions } \\
\text { What uterine evacuation techniques are used in } \\
\text { this health facility to treat postabortion clients? }\end{array}$} & \multicolumn{3}{|c|}{ Coding Categories } & Go to \\
\hline & & \multicolumn{2}{|c|}{$\begin{array}{l}\text { Manual Vacuum Aspiration } \\
\text { (MVA) }\end{array}$} & $\mathrm{I}$ & \\
\hline & & \multicolumn{2}{|c|}{ Electric vacuum aspiration } & 2 & \\
\hline & & \multicolumn{2}{|c|}{$\begin{array}{l}\text { Dilatation and Curettage } \\
\text { (D\&C) }\end{array}$} & 3 & \\
\hline & & \multicolumn{2}{|l|}{ Other: } & 77 & \\
\hline 6.2 & $\begin{array}{l}\text { How many providers at the facility have been } \\
\text { trained in uterine evacuation? }\end{array}$ & & & & \\
\hline \multirow[t]{5}{*}{6.3} & $\begin{array}{l}\text { Does the facility have providers trained in uterine } \\
\text { evacuation in the three shifts? }\end{array}$ & Yes & \multicolumn{2}{|l|}{ No } & \multirow{5}{*}{6.4} \\
\hline & Shifts are not used at this facility & I & \multicolumn{2}{|c|}{2} & \\
\hline & Morning & $\mathrm{I}$ & \multicolumn{2}{|c|}{2} & \\
\hline & Afternoon & I & \multicolumn{2}{|c|}{2} & \\
\hline & Night & $\mathrm{I}$ & \multicolumn{2}{|c|}{2} & \\
\hline \multirow[t]{2}{*}{6.4} & \multirow[t]{2}{*}{ Does this facility have providers trained in MVA? } & \multicolumn{2}{|l|}{ Yes } & I & \\
\hline & & \multicolumn{2}{|l|}{ No } & \multicolumn{2}{|l|}{2} \\
\hline \multicolumn{6}{|c|}{ Interviewer: Check 3.5. If this facility does not offer PAC services, go to 8.I } \\
\hline \multirow[t]{4}{*}{6.5} & $\begin{array}{l}\text { Does the facility have providers trained in MVA } \\
\text { in the three shifts? }\end{array}$ & Yes & \multicolumn{2}{|l|}{ No } & \\
\hline & Morning & I & \multicolumn{2}{|c|}{2} & \\
\hline & Afternoon & I & \multicolumn{2}{|c|}{2} & \\
\hline & Night & I & \multicolumn{2}{|c|}{2} & \\
\hline \multirow[t]{2}{*}{6.6} & \multirow{2}{*}{$\begin{array}{l}\text { Can a postabortion client be discharged at any } \\
\text { time of day? }\end{array}$} & \multicolumn{2}{|l|}{ Yes } & I & \\
\hline & & \multicolumn{2}{|l|}{ No } & 2 & \\
\hline \multirow[t]{3}{*}{6.7} & \multirow{3}{*}{$\begin{array}{l}\text { What is the average hospital stay for } \\
\text { postabortion clients? }\end{array}$} & \multicolumn{2}{|l|}{ Minutes: } & & \\
\hline & & \multicolumn{2}{|l|}{ Hours: } & & \\
\hline & & \multicolumn{2}{|l|}{ Days: } & & \\
\hline
\end{tabular}


7. PAC quality

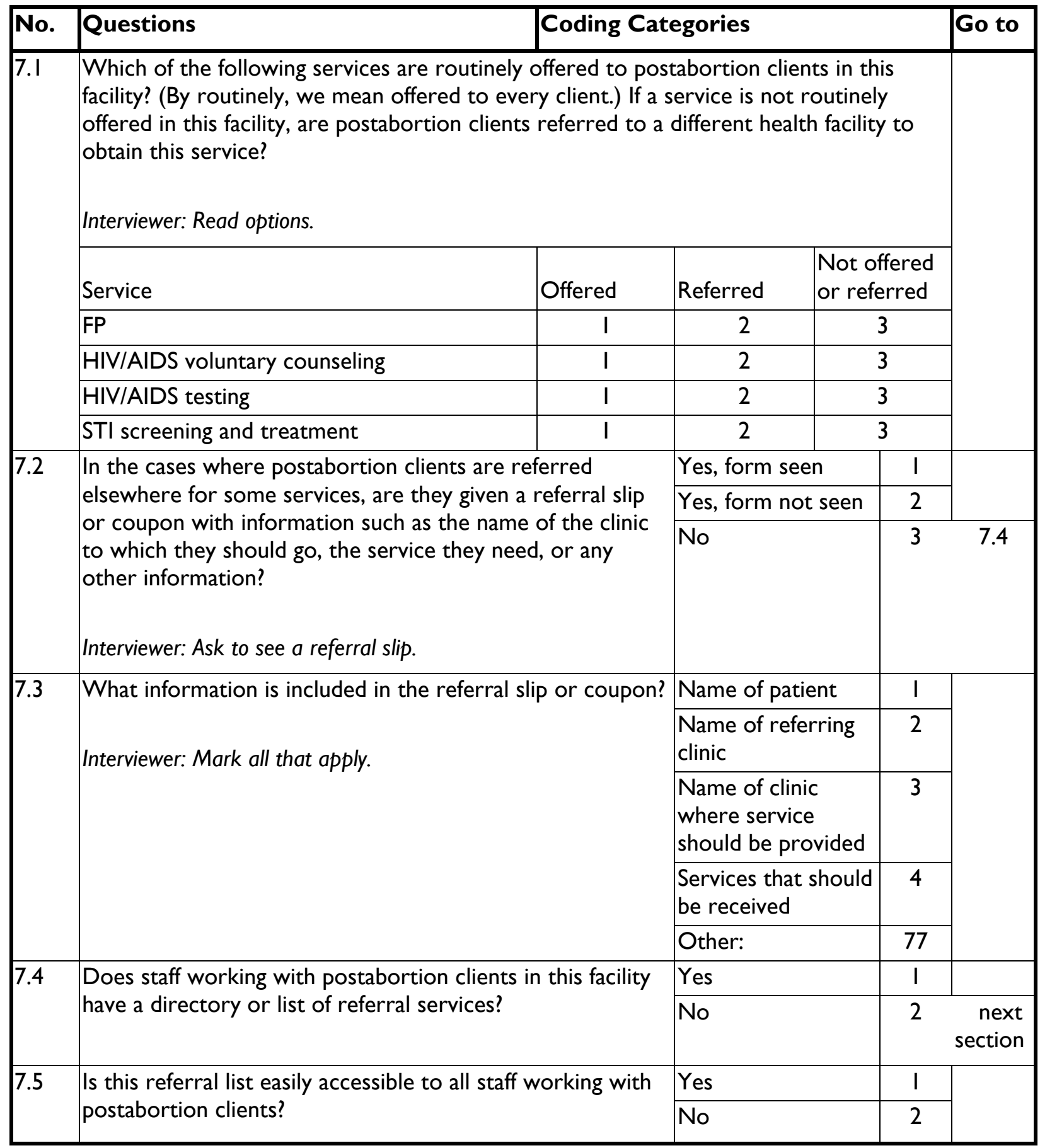




\section{PAC examination rooms}

\begin{tabular}{|l|l|l|l|}
\hline No. & Questions & \multicolumn{2}{l|}{ Coding Categories } \\
\hline Interviewer: Ask to see the area where women with obstetric emergencies are first examined. For the following \\
items, check whether the item is in the area or in an adjacent room.
\end{tabular}

Interviewer: Check 3.5. If this facility does not offer PAC services, go to I0.I 4 
9. PAC treatment rooms and equipment

\begin{tabular}{|l|l|l}
\hline No. & QUESTIONS & CODING CATEGORIES \\
\hline
\end{tabular}

Interviewer: Ask to see the area where the therapeutic procedures (D\&C or MVA) take place for postabortion clients. For the following items, check whether the item is in the area or in an adjacent room.

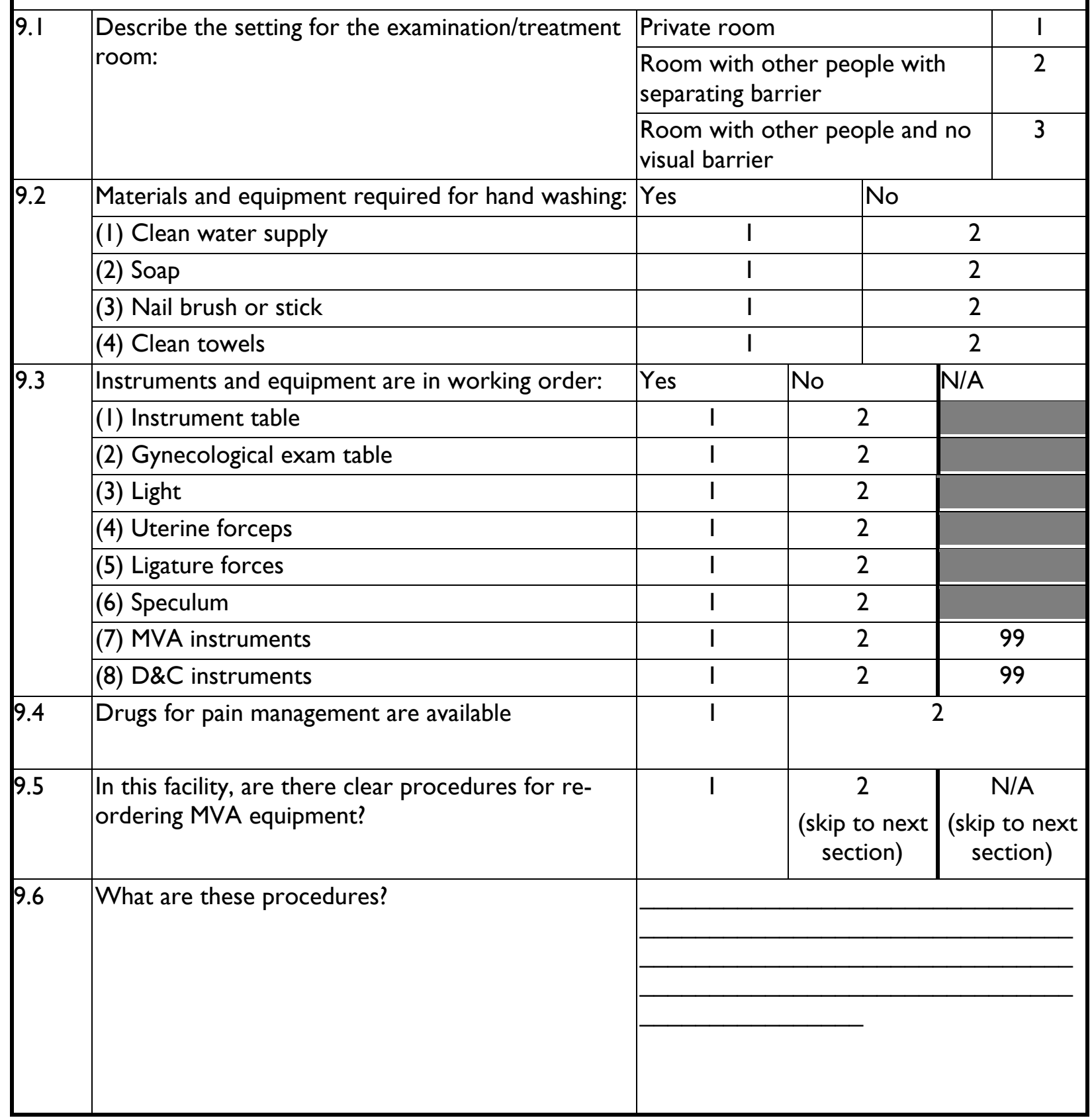


I0. FP services in PAC

\begin{tabular}{|c|c|c|c|c|c|c|}
\hline \multirow{2}{*}{\begin{tabular}{|l|} 
No. \\
10.1
\end{tabular}} & \multirow{2}{*}{$\begin{array}{l}\text { Questions } \\
\text { Is (read I to 3) available to clients in this } \\
\text { health facility? How many days per week } \\
\text { are (read I to 3) services offered? }\end{array}$} & \multicolumn{4}{|c|}{ Coding Categories } & \multirow[t]{2}{*}{ Go to } \\
\hline & & Yes & \multicolumn{2}{|c|}{ No } & Days & \\
\hline & I) FP counseling & 1 & & 2 & & \\
\hline & 2) Contraceptives & I & & 2 & & \\
\hline & 3) Antenatal care & 1 & & 2 & & \\
\hline \multirow[t]{4}{*}{10.2} & \multirow{4}{*}{$\begin{array}{l}\text { Do the hours of operation of FP services } \\
\text { coincide with the hours of operation and } \\
\text { discharge of PAC clients? }\end{array}$} & \multicolumn{3}{|c|}{$\begin{array}{l}\text { Yes. Whenever PAC clients are } \\
\text { discharged, FP services are open. }\end{array}$} & 1 & \\
\hline & & \multicolumn{3}{|c|}{$\begin{array}{l}\text { Sometimes. There are times when } \\
\text { postabortion clients are discharged } \\
\text { that FP services are closed. Explain: }\end{array}$} & 2 & \\
\hline & & \multicolumn{3}{|c|}{$\begin{array}{l}\text { No. Whenever PAC clients are } \\
\text { discharged, FP services are closed. }\end{array}$} & 3 & \\
\hline & & \multicolumn{3}{|l|}{ Other: } & 77 & \\
\hline \multirow[t]{14}{*}{10.3} & \multicolumn{5}{|c|}{$\begin{array}{l}\text { How many providers and of which type (qualifications) are assigned to work in PAC in } \\
\text { this facility? Of the staff involved in PAC, how many have as one of their responsibilities } \\
\text { giving FP to PAC clients? }\end{array}$} & \\
\hline & Type of staff & & \multicolumn{2}{|c|}{$\begin{array}{l}\text { PAC providers that } \\
\text { give FP to PAC clients }\end{array}$} & \\
\hline & I) Medical specialists & \multicolumn{2}{|l|}{ PAC } & \multicolumn{2}{|c|}{ give FP to PAC clients } & \\
\hline & \multicolumn{5}{|l|}{ 2) General practitioners } & \\
\hline & \multicolumn{5}{|l|}{ 3) Medical residents } & \\
\hline & \multicolumn{5}{|l|}{ 4) Medical interns } & \\
\hline & \multicolumn{5}{|l|}{ 5) Clinical officers } & \\
\hline & \multicolumn{5}{|l|}{ 6) Trained midwives } & \\
\hline & \multicolumn{5}{|l|}{ 7) Registered nurse } & \\
\hline & \multicolumn{5}{|l|}{ 8) Enrolled nurse } & \\
\hline & \multicolumn{5}{|l|}{ 9) Nursing student } & \\
\hline & \multicolumn{5}{|l|}{ 10) Social worker } & \\
\hline & \multicolumn{5}{|l|}{ II) Other I: } & \\
\hline & \multicolumn{5}{|l|}{ II) Other 2: } & \\
\hline \multirow[t]{3}{*}{10.4} & \multirow{3}{*}{$\begin{array}{l}\text { Are there any indicators for the provision } \\
\text { of FP services to postabortion clients } \\
\text { systematically reviewed in the facility } \\
\text { quality-monitoring activities (e.g., in } \\
\text { monthly meetings)? }\end{array}$} & \multicolumn{3}{|c|}{ Yes, explain how: } & $\mathrm{I}$ & \\
\hline & & No & & & 2 & \\
\hline & & Other: & & & 77 & \\
\hline
\end{tabular}




\begin{tabular}{|c|c|c|c|c|}
\hline \multirow[t]{4}{*}{10.5} & \multirow[t]{4}{*}{$\begin{array}{l}\text { Are there any written guidelines in this } \\
\text { facility for postabortion services? }\end{array}$} & $\begin{array}{l}\text { Yes, guidelines are available } \\
\text { Interviewer: Write name of guidelines. }\end{array}$ & 1 & \\
\hline & & & & \\
\hline & & Yes, but guidelines aren't available. & 2 & \\
\hline & & No, there aren't written guidelines. & 3 & 10.8 \\
\hline \multirow[t]{2}{*}{10.6} & \multirow{2}{*}{$\begin{array}{l}\text { Do these guidelines or service protocols } \\
\text { recommend that FP services (e.g., } \\
\text { counseling) are offered to postabortion } \\
\text { clients as a part of PAC? }\end{array}$} & Yes, explain how: & 1 & \\
\hline & & No & 2 & \\
\hline \multirow[t]{4}{*}{10.7} & \multirow{4}{*}{$\begin{array}{l}\text { Do these guidelines or service protocols } \\
\text { recommend that postabortion clients be } \\
\text { referred to FP services elsewhere? }\end{array}$} & Yes, explain how: & $\mathrm{I}$ & \\
\hline & & & & \\
\hline & & No & 2 & \\
\hline & & Don't know & 98 & \\
\hline \multirow[t]{2}{*}{10.8} & \multirow{2}{*}{$\begin{array}{l}\text { Is FP counseling routinely offered to } \\
\text { postabortion clients in this facility? (By } \\
\text { routinely, we mean offered to most } \\
\text { clients.) }\end{array}$} & Yes & $\mathrm{I}$ & \\
\hline & & No & 2 & 10.13 \\
\hline \multirow[t]{3}{*}{10.9} & \multirow{3}{*}{$\begin{array}{l}\text { Do postabortion clients receive FP } \\
\text { counseling before they are discharged } \\
\text { from PAC? }\end{array}$} & Yes, explain: & 1 & \\
\hline & & No & 2 & \\
\hline & & Other, explain: & 77 & \\
\hline \multirow[t]{3}{*}{10.10} & \multirow{3}{*}{$\begin{array}{l}\text { Who gives FP counseling to postabortion } \\
\text { clients? The same provider who gives } \\
\text { them PAC or someone else? }\end{array}$} & Same provider & $\mathrm{I}$ & \\
\hline & & Someone else & 2 & \\
\hline & & Other: & 77 & \\
\hline \multirow[t]{3}{*}{10.11} & \multirow[t]{3}{*}{$\begin{array}{l}\text { Where do postabortion clients receive FP } \\
\text { counseling? }\end{array}$} & $\begin{array}{l}\text { In the same area where they } \\
\text { receive PAC }\end{array}$ & $\mathrm{I}$ & 10.13 \\
\hline & & In the FP area in this facility & 2 & \\
\hline & & Other: & 77 & \\
\hline \multirow[t]{5}{*}{10.12} & \multirow{5}{*}{$\begin{array}{l}\text { Why is FP counseling not provided in the } \\
\text { same area where women receive PAC? }\end{array}$} & There is no staff available. & $\mathrm{I}$ & \\
\hline & & Staff is not trained. & 2 & \\
\hline & & $\begin{array}{l}\text { The facility does not have the } \\
\text { necessary equipment. }\end{array}$ & 3 & \\
\hline & & There is insufficient room/space. & 4 & \\
\hline & & Other: & 77 & \\
\hline
\end{tabular}




\begin{tabular}{|c|c|c|c|c|c|c|}
\hline \multirow[t]{3}{*}{10.13} & \multirow{3}{*}{$\begin{array}{l}\text { Where do postabortion clients who want } \\
\text { to obtain a contraceptive method receive } \\
\text { the method? }\end{array}$} & \multicolumn{4}{|c|}{$\begin{array}{l}\text { In the same area where they } \\
\text { receive PAC }\end{array}$} & I \\
\hline & & \multicolumn{4}{|c|}{ In the FP area in this facility } & 2 \\
\hline & & \multicolumn{4}{|c|}{ Other: } & 77 \\
\hline \multirow[t]{25}{*}{10.14} & \multicolumn{6}{|c|}{$\begin{array}{l}\text { Which of the following contraceptive methods are available for [postabortion } \\
\text { clients/clients in general]? Of these, which are available at any time, and which are } \\
\text { offered on a limited schedule? }\end{array}$} \\
\hline & \multirow{2}{*}{ Method } & \multicolumn{2}{|c|}{\begin{tabular}{|l} 
Available for \\
postabortion clients?
\end{tabular}} & \multicolumn{3}{|c|}{ Available any time? } \\
\hline & & Yes & No & Yes & No & \\
\hline & I) Combined oral contraceptives & I & 2 & I & & 2 \\
\hline & 2) Minipills (progestin-only pills) & I & 2 & I & & 2 \\
\hline & 3) Emergency contraceptive pills & I & 2 & I & & 2 \\
\hline & $\begin{array}{l}\text { 4) Progestin-only injectables (injection } \\
\text { every } 2 \text { or } 3 \text { months) }\end{array}$ & I & 2 & I & & 2 \\
\hline & 5) Monthly injectables & I & 2 & I & & 2 \\
\hline & 6) Combined patches & I & 2 & $\mathrm{I}$ & & 2 \\
\hline & 7) Combined vaginal rings & I & 2 & $\mathrm{I}$ & & 2 \\
\hline & 8) Jadelle implants & I & 2 & 1 & & 2 \\
\hline & 9) Implanon implants & I & 2 & I & & 2 \\
\hline & I0) Sinoplant (II) implants & I & 2 & I & & 2 \\
\hline & III) IUD & I & 2 & $\mathrm{I}$ & & 2 \\
\hline & I2) IUS & I & 2 & $\mathrm{I}$ & & 2 \\
\hline & 13) Male condoms & I & 2 & I & & 2 \\
\hline & I4) Female condoms & I & 2 & I & & 2 \\
\hline & 15) Diaphragms & I & 2 & $\mathrm{I}$ & & 2 \\
\hline & 16) Spermicides & I & 2 & $\mathrm{I}$ & & 2 \\
\hline & 17) Cervical caps & I & 2 & I & & 2 \\
\hline & 18) Female sterilization & I & 2 & I & & 2 \\
\hline & 19) Vasectomy & I & 2 & $\mathrm{I}$ & & 2 \\
\hline & 20) Fertility awareness methods & I & 2 & $\mathrm{I}$ & & 2 \\
\hline & 2I) Withdrawal & I & 2 & I & & 2 \\
\hline & 22) Other: & I & 2 & $\mathrm{I}$ & & 2 \\
\hline Intervic & ewer: Check 3.5. If this facility does not offer & PAC se & vices, go to 10.1 & & & \\
\hline 10.15 & $\begin{array}{l}\text { Are postabortion clients who are interes } \\
\text { receiving a contraceptive method that is }\end{array}$ & $\begin{array}{l}\text { sted in } \\
\text { not }\end{array}$ & $\begin{array}{l}\text { Yes, referred } \\
\text { this facility }\end{array}$ & o FP serv & s in & $\mathrm{I}$ \\
\hline & $\begin{array}{l}\text { available in the same area where they re } \\
\text { PAC routinely referred to FP services in }\end{array}$ & $\begin{array}{l}\text { ceive } \\
\text { this }\end{array}$ & $\begin{array}{l}\text { Yes, referred } \\
\text { (specify) }\end{array}$ & lsewhere & & 2 \\
\hline & $\begin{array}{l}\text { facility or to another place where they } \\
\text { their desired method? }\end{array}$ & an get & No & & & 3 \\
\hline & & & Other: & & & 77 \\
\hline
\end{tabular}




\begin{tabular}{|c|c|c|c|c|c|}
\hline \multirow[t]{5}{*}{10.16} & $\begin{array}{l}\text { Interviewer: Obtain the following information from } \\
\text { the service statistics. }\end{array}$ & $\begin{array}{l}\text { Last } 12 \\
\text { months }\end{array}$ & $\begin{array}{l}\text { Last } 6 \\
\text { months }\end{array}$ & $\begin{array}{l}\text { Last } \\
\text { month }\end{array}$ & $\begin{array}{l}\text { Info not } \\
\text { available }\end{array}$ \\
\hline & Number of PAC clients & & & & \\
\hline & $\begin{array}{l}\text { Number of PAC clients who received FP } \\
\text { counselling }\end{array}$ & & & & \\
\hline & $\begin{array}{l}\text { Number of PAC clients who received a } \\
\text { contraceptive before discharge }\end{array}$ & & & & \\
\hline & $\begin{array}{l}\text { Number of PAC clients who were referred to } \\
\text { FP services }\end{array}$ & & & & \\
\hline \multirow[t]{27}{*}{10.17} & \multicolumn{2}{|c|}{$\begin{array}{l}\text { On the date of visit, which of the following } \\
\text { contraceptives were available for [PAC clients/clients in } \\
\text { general]? } \\
\text { [INTERVIEWER HAS TO ACTUALLY CHECK TO } \\
\text { VERIFY] }\end{array}$} & \multicolumn{2}{|l|}{ Available } & Not available \\
\hline & \multicolumn{2}{|l|}{ I) Combined oral contraceptives } & & & \\
\hline & \multicolumn{2}{|l|}{ 2) Progestin-only pills } & & & \\
\hline & \multicolumn{2}{|l|}{ 3) Emergency contraceptive pills (prepacked) } & & & \\
\hline & \multicolumn{2}{|l|}{ 4) Emergency contraceptive pills (not prepacked) } & & & \\
\hline & \multicolumn{2}{|l|}{ 5) Progestin-only injectables } & & & \\
\hline & \multicolumn{2}{|l|}{ 6) Monthly injectables } & & & \\
\hline & \multicolumn{2}{|l|}{ 7) Combined patches } & & & \\
\hline & \multicolumn{2}{|l|}{ 8) Combined vaginal rings } & & & \\
\hline & \multicolumn{2}{|l|}{ 9) Jadelle implants } & & & \\
\hline & \multicolumn{2}{|l|}{ I0) Implanon implants } & & & \\
\hline & \multicolumn{2}{|l|}{ II) Trocar } & & & \\
\hline & \multicolumn{2}{|l|}{ 12) Scalpel } & & & \\
\hline & \multicolumn{2}{|l|}{ 13) Straight forceps } & & & \\
\hline & \multicolumn{2}{|l|}{ 14) Local Anesthesia } & & & \\
\hline & \multicolumn{2}{|l|}{ III) IUD } & & & \\
\hline & \multicolumn{2}{|l|}{ 12) lodine } & & & \\
\hline & \multicolumn{2}{|l|}{ 13) Cervical Tenaculum } & & & \\
\hline & \multicolumn{2}{|l|}{ 14) Sponge Forceps } & & & \\
\hline & \multicolumn{2}{|l|}{ 15) Uterine Sound } & & & \\
\hline & \multicolumn{2}{|l|}{ 16) Operating Scissors } & & & \\
\hline & \multicolumn{2}{|l|}{ 17) Speculum } & & & \\
\hline & \multicolumn{2}{|l|}{ I2) IUS } & & & \\
\hline & \multicolumn{2}{|l|}{ 13) Male condoms } & & & \\
\hline & \multicolumn{2}{|l|}{ 14) Female condoms } & & & \\
\hline & \multicolumn{2}{|l|}{ 17) Female sterilization } & & & \\
\hline & 18) Vasectomy & & & & \\
\hline
\end{tabular}

Interviewer: Check 3.5. If this facility does not offer PAC services, go to I2.I 


\section{I. Record keeping}

\begin{tabular}{|c|c|c|c|c|c|}
\hline \multirow{3}{*}{\begin{tabular}{|l|} 
No. \\
II.I
\end{tabular}} & \multirow{3}{*}{\begin{tabular}{|l} 
Questions \\
Is there a daily activity record for PAC in this facility?
\end{tabular}} & \multicolumn{4}{|c|}{ Coding Categories } \\
\hline & & \multicolumn{3}{|l|}{ Yes } & $\mathrm{I}$ \\
\hline & & \multicolumn{3}{|l|}{ No } & 2 \\
\hline \multirow[t]{4}{*}{11.2} & $\begin{array}{l}\text { Interviewer: Complete this information using the available } \\
\text { statistics from the last I } 2 \text { months. }\end{array}$ & $\begin{array}{l}\text { Last I2 } \\
\text { months }\end{array}$ & $\begin{array}{l}\text { Last } 6 \\
\text { months }\end{array}$ & $\begin{array}{l}\text { Last } \\
\text { month }\end{array}$ & Info not \\
\hline & Number of postabortion clients treated with MVA & & & & \\
\hline & Number of postabortion clients treated with D\&C & & & & \\
\hline & $\begin{array}{l}\text { Number of postabortion clients treated with dilatation } \\
\text { curage }\end{array}$ & & & & \\
\hline
\end{tabular}

\section{Supervision}

\begin{tabular}{|c|c|c|c|c|}
\hline \multirow{4}{*}{\begin{tabular}{|l} 
No. \\
I2.I
\end{tabular}} & \multirow{4}{*}{\begin{tabular}{|l} 
QUESTIONS \\
Does this facility have any system for \\
determining clients' opinions about the health \\
facility or services?
\end{tabular}} & \multicolumn{2}{|l|}{ CODING CATEGORIES } & \multirow[t]{2}{*}{ GO TO } \\
\hline & & Yes & 1 & \\
\hline & & No & 2 & 12.3 \\
\hline & & Unsure & 3 & 12.3 \\
\hline \multirow[t]{2}{*}{12.2} & \multirow{2}{*}{$\begin{array}{l}\text { In the past } 3 \text { months, have any changes been } \\
\text { made in the facility as a result of client } \\
\text { opinion? }\end{array}$} & Yes & I & \\
\hline & & No & 2 & \\
\hline \multirow[t]{2}{*}{12.3} & \multirow{2}{*}{$\begin{array}{l}\text { Does this facility have a method for } \\
\text { monitoring the quality of care provided to } \\
\text { clients? }\end{array}$} & Yes & I & \\
\hline & & No & \multirow[t]{2}{*}{2} & 12.6 \\
\hline 12.4 & What is done to monitor quality of care? & & & \\
\hline \multicolumn{5}{|c|}{ Interviewer: Check 3.5. If this facility does not offer PAC services, go to I 2.6} \\
\hline \multirow[t]{3}{*}{12.5} & \multirow{3}{*}{$\begin{array}{l}\text { Are there any indicators for PAC } \\
\text { systematically reviewed in these quality- } \\
\text { monitoring activities? }\end{array}$} & Yes & I & \\
\hline & & No & 2 & \\
\hline & & Other: & 77 & \\
\hline \multirow[t]{5}{*}{12.6} & \multirow{5}{*}{$\begin{array}{l}\text { Who is responsible for reviewing findings and } \\
\text { taking action relative to quality of care } \\
\text { activities? }\end{array}$} & Individual service provision staff & $\mathrm{I}$ & \\
\hline & & Individual supervisors & 2 & \\
\hline & & Internal management/quality team & 3 & \\
\hline & & External management team & 4 & \\
\hline & & Other: & 77 & \\
\hline \multirow[t]{3}{*}{12.7} & \multirow{3}{*}{$\begin{array}{l}\text { When was the last time an external } \\
\text { supervisor (someone from outside this } \\
\text { facility) visited the facility? }\end{array}$} & Within the last 6 months & I & \\
\hline & & More than 6 months ago & 2 & $\begin{array}{r}\text { next } \\
\text { section }\end{array}$ \\
\hline & & No external supervision & 3 & $\begin{array}{r}\text { next } \\
\text { section }\end{array}$ \\
\hline
\end{tabular}




\begin{tabular}{|c|c|c|c|}
\hline \multirow[t]{9}{*}{12.8} & \multirow{9}{*}{$\begin{array}{l}\text { The last time within the last } 6 \text { months that a } \\
\text { supervisor from outside the facility visited, did } \\
\text { the supervisor do the following. } \\
\text { Interviewer: Read options and mark all that apply. } \\
\text { Ask "Something else?" }\end{array}$} & Check records? & I \\
\hline & & Discuss problems? & 2 \\
\hline & & $\begin{array}{l}\text { Discuss policy/administrative } \\
\text { issues? }\end{array}$ & 3 \\
\hline & & $\begin{array}{l}\text { Discuss technical protocols/ } \\
\text { practice? }\end{array}$ & 4 \\
\hline & & Hold an official staff meeting? & 5 \\
\hline & & $\begin{array}{l}\text { Observe individual staff providing } \\
\text { services? }\end{array}$ & 6 \\
\hline & & $\begin{array}{l}\text { Provide service providers with } \\
\text { updates on contraceptives? }\end{array}$ & 7 \\
\hline & & $\begin{array}{l}\text { Provide service providers with } \\
\text { updates on post-abortion care? }\end{array}$ & 8 \\
\hline & & Other: & 77 \\
\hline
\end{tabular}

Interviewer: Check 3.5. If this facility does not offer PAC services, go to I4.I

\section{IEC materials}

\begin{tabular}{|l|l|l|}
\hline No. & Questions & Coding Categories \\
\hline
\end{tabular}

Interviewer: Verify that the following materials are available in the room where PAC clients receive counseling.

\begin{tabular}{|c|c|c|c|}
\hline \multirow{6}{*}{ |3.1 } & Visual aids for teaching about: & Yes & No \\
\hline & I) Different FP methods & I & 2 \\
\hline & 2) Model for demonstrating condom use & I & 2 \\
\hline & 3) PAC & I & 2 \\
\hline & 4) STIs & $\mathrm{I}$ & 2 \\
\hline & 5) HIVIAIDS & I & 2 \\
\hline \multirow[t]{6}{*}{13.2} & Information booklets/leaflets for clients to take home: & Yes & No \\
\hline & I) Different FP methods & I & 2 \\
\hline & 2) Model for demonstrating condom use & $\mathrm{I}$ & 2 \\
\hline & 3) PAC & I & 2 \\
\hline & 4) STIs & I & 2 \\
\hline & 5) HIVIAIDS & 1 & 2 \\
\hline
\end{tabular}




\section{Costs}

\begin{tabular}{|c|c|c|c|c|c|}
\hline No. & \multicolumn{5}{|l|}{ QUESTIONS } \\
\hline 14.1 & \multicolumn{5}{|c|}{$\begin{array}{l}\text { What are clients charged for obtaining the following services, commodities, tests, or } \\
\text { procedures? } \\
\text { Interviewer: Ask questions I4.I to I } 4.3 \text { and register answers in the table below. If PAC services are not } \\
\text { offered at this facility, skip the first option 'treatment of incomplete abortion.' }\end{array}$} \\
\hline 14.2 & \multicolumn{5}{|c|}{ Is there a waiver or exemption policy for women who cannot pay? } \\
\hline 14.3 & \multicolumn{5}{|c|}{ Who is exempted from paying these fees? } \\
\hline \multirow{2}{*}{\multicolumn{2}{|c|}{ Service or commodity }} & \multirow{2}{*}{$\begin{array}{l}\text { I4.1 } \\
\text { Charge in local } \\
\text { currency }\end{array}$} & \multicolumn{2}{|c|}{$\begin{array}{l}\text { I } 4.2 \\
\text { Is there a waiver or } \\
\text { exemption policy? }\end{array}$} & \multirow{2}{*}{$\begin{array}{l}14.3 \\
\text { Who is exempted from } \\
\text { paying these fees? }\end{array}$} \\
\hline & & & Yes & No & \\
\hline \multicolumn{2}{|c|}{$\begin{array}{l}\text { Treatment of incomplete } \\
\text { abortion }\end{array}$} & Ksh & I & 2 & \\
\hline \multicolumn{2}{|c|}{ FP counseling } & Ksh & $\mathrm{I}$ & 2 & \\
\hline \multicolumn{2}{|c|}{ Combined oral contraceptives } & Ksh & I & 2 & \\
\hline \multicolumn{2}{|c|}{ Minipills (progestin-only pills) } & Ksh & $\mathrm{I}$ & 2 & \\
\hline \multicolumn{2}{|c|}{ Emergency contraceptive pills } & Ksh & $\mathrm{I}$ & 2 & \\
\hline \multicolumn{2}{|c|}{$\begin{array}{l}\text { Progestin-only injectables } \\
\text { (injection every } 2 \text { or } 3 \text { months) }\end{array}$} & Ksh & 1 & 2 & \\
\hline \multicolumn{2}{|c|}{ Monthly injectables } & Ksh & $\mathrm{I}$ & 2 & \\
\hline \multicolumn{2}{|c|}{ Combined patches } & Ksh & I & 2 & \\
\hline \multicolumn{2}{|c|}{ Combined vaginal rings } & Ksh & $\mathrm{I}$ & 2 & \\
\hline \multicolumn{2}{|c|}{ Jadelle implants } & Ksh & 1 & 2 & \\
\hline \multicolumn{2}{|c|}{ Implanon implants } & Ksh & 1 & 2 & \\
\hline \multicolumn{2}{|c|}{ Sinoplant (II) implants } & Ksh & 1 & 2 & \\
\hline \multicolumn{2}{|l|}{ IUD } & Ksh & 1 & 2 & \\
\hline \multicolumn{2}{|l|}{ IUS } & Ksh & I & 2 & \\
\hline \multicolumn{2}{|c|}{ Male condoms } & Ksh & 1 & 2 & \\
\hline \multicolumn{2}{|c|}{ Female condoms } & Ksh & 1 & 2 & \\
\hline \multicolumn{2}{|c|}{ Diaphragms } & Ksh & 1 & 2 & \\
\hline \multicolumn{2}{|c|}{ Spermicides } & Ksh & 1 & 2 & \\
\hline \multicolumn{2}{|c|}{ Cervical caps } & Ksh & 1 & 2 & \\
\hline \multicolumn{2}{|c|}{ Female sterilization } & Ksh & I & 2 & \\
\hline \multicolumn{2}{|c|}{ Vasectomy } & Ksh & $\mathrm{I}$ & 2 & \\
\hline \multicolumn{2}{|c|}{ HIVIAIDS testing } & Ksh & $\mathrm{I}$ & 2 & \\
\hline \multicolumn{2}{|c|}{ Syphilis testing } & Ksh & $\mathrm{I}$ & 2 & \\
\hline Other & STI testing & Ksh & I & 2 & \\
\hline
\end{tabular}




\section{Referral System}

I5.I Can you please describe the referral system that is in place for clients that may need to be referred to another facility?

Interviewer: Probe for the following and circle all mentioned:

\begin{tabular}{|l|l|l|}
\hline & Yes & No \\
\hline 1) Availability of referral forms & $I$ & 2 \\
\hline 2) Availability of emergency transportation & $I$ & 2 \\
\hline 3) Telephone communication between health facilities & $I$ & 2 \\
\hline 4) Patient is escorted to facility by a health provider & $I$ & 2 \\
\hline 5) Other (specify): & 1 & 2 \\
& & \\
& & \\
\hline
\end{tabular}




\section{Provider Interview \\ Evaluation of the Replication of the Community \\ Post-Abortion Care Model in Kenya \\ Population Council \\ [TO BE ADMINISTERED ONLY AT FACILITIES THAT OFFER PAC]}

INSTRUCTIONS FOR THE INTERVIEWERS: Interview all health facility staff who are responsible for providing PAC, including FP services, to PAC clients. Please interview staff at the end of the working day or during their breaks. Make it clear that you are seeking their assistance in finding ways of improving the functioning and quality of the services offered by facilities in general and are not evaluating the performance of the facility or of them individually. For each item, circle the code of the adequate response or describe, as appropriate. Read the following greeting when you meet with each provider that you will interview.

GREETING: Good morning. My name is , and I work for the Population Council. We are currently doing a study about the way that FP services are provided during post-abortion care in Kenya. As a part of this study, we are interviewing all health providers who participate in post-abortion care, including FP services for post-abortion women. These interviews are not to evaluate individual facilities or providers. We are visiting a number of facilities. All the information you give me will be confidential, and no one will know what you said. I will not record your name in the questionnaire, and there will be no way in which the responses you give me can be directly linked to you. They will all be confidential. The research we are conducting will be used to improve PAC services and we have sought permission from the district health authorities to carry out this study.

\section{Facility identification}

\begin{tabular}{|c|c|c|c|}
\hline No. & QUESTIONS & \multicolumn{2}{|l|}{ CODING CATEGORIES } \\
\hline \multirow[t]{2}{*}{1.1} & Date of interview & $I^{\prime}+I^{\prime}$ & \\
\hline & & \multicolumn{2}{|l|}{ (Day/ Month/ Year) } \\
\hline 1.2 & Community Unit & & \\
\hline 1.3 & Facility name & & \\
\hline \multirow[t]{7}{*}{1.4} & \multirow[t]{7}{*}{ Type of facility } & Hospital & 1 \\
\hline & & Health center with maternity ward & 2 \\
\hline & & Health center without maternity ward & 3 \\
\hline & & Health post with maternity ward & 4 \\
\hline & & Health post without maternity ward & 5 \\
\hline & & Dispensary & 6 \\
\hline & & Other: & 77 \\
\hline \multirow[t]{4}{*}{1.5} & \multirow[t]{4}{*}{ Result of the interview } & Complete & 1 \\
\hline & & Incomplete & 2 \\
\hline & & Refused & 3 \\
\hline & & Other: & 4 \\
\hline
\end{tabular}


2. Demographics and professional experience

\begin{tabular}{|c|c|c|c|}
\hline No. & Questions & Coding Categories & \\
\hline 2.1 & Sex & Male & $\mathrm{I}$ \\
\hline & Interviewer: Please mark. & Female & 2 \\
\hline 2.2 & How old are you? & Age in years: & \\
\hline 2.3 & What is your current technical qualification? & Specialist doctor & 1 \\
\hline & & General doctor & 2 \\
\hline & & Clinical officer & 3 \\
\hline & & Intern MD student & 4 \\
\hline & & Registered nurse & 5 \\
\hline & & Enrolled nurse & 6 \\
\hline & & Nursing student & 7 \\
\hline & & Social worker & 8 \\
\hline & & Other: & 77 \\
\hline 2.4 & $\begin{array}{l}\text { How many years ago did you graduate with this } \\
\text { diploma/certificate? }\end{array}$ & Years: & \\
\hline 2.5 & How long have you been working at this facility? & Months: & \\
\hline & & Years: & \\
\hline 2.6 & In which unit or department are you currently & Facility not divided into departments & 1 \\
\hline & & PAC & 2 \\
\hline & & FP & 3 \\
\hline & & Other & 77 \\
\hline 2.7 & What services do you directly provide at this & FP counseling & 1 \\
\hline & facility? & Contraceptives & 2 \\
\hline & Interviewer: Mark all that abblv & Antenatal care & 3 \\
\hline & & Delivery & 4 \\
\hline & & Postpartum care & 5 \\
\hline & & Treatment of abortion complications & 6 \\
\hline & & HIV/AIDS counseling & 7 \\
\hline & & HIVIAIDS testing & 8 \\
\hline & & HIV/AIDS treatment and care & 9 \\
\hline & & STI services & 10 \\
\hline & & Child immunization & II \\
\hline & & Child growth monitoring & 12 \\
\hline & & Curative services for women & 13 \\
\hline & & Curative services for children & 14 \\
\hline & & Other: & 77 \\
\hline
\end{tabular}




\section{Integration of PAC and FP}

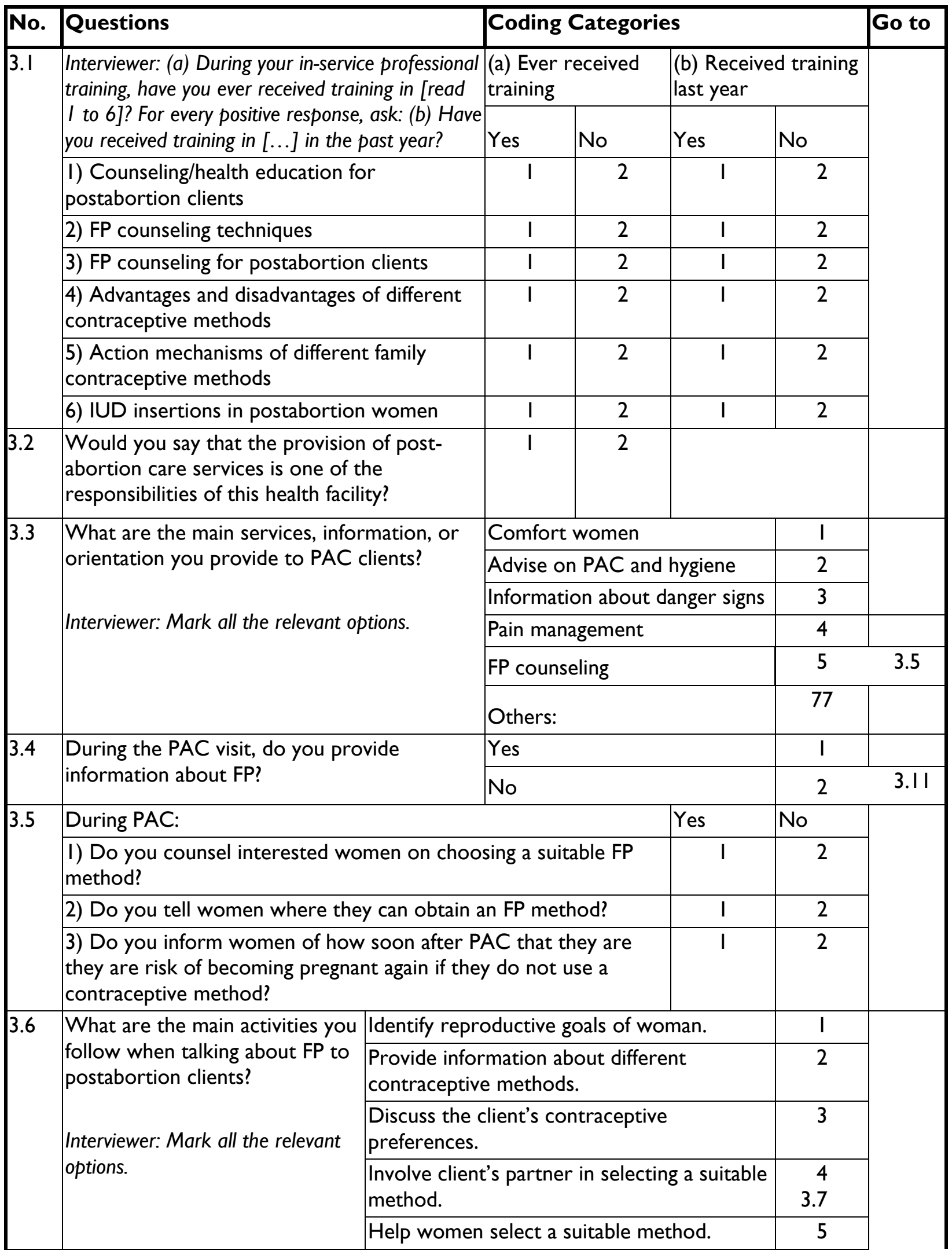




\begin{tabular}{|c|c|c|c|c|c|c|}
\hline & & \multicolumn{4}{|c|}{$\begin{array}{l}\text { Instruct women in how to use the selected } \\
\text { method. }\end{array}$} & 6 \\
\hline & & \multicolumn{4}{|c|}{$\begin{array}{l}\text { Emphasize special services/considerations for } \\
\text { young people, if applicable. }\end{array}$} & 7 \\
\hline & & \multicolumn{4}{|l|}{ Other: } & 8 \\
\hline 3.7 & \multicolumn{6}{|c|}{ In what specific ways do you involve men when talking about FP to PAC clients? } \\
\hline \multirow[t]{23}{*}{3.8} & \multirow{6}{*}{\multicolumn{6}{|c|}{$\begin{array}{l}\text { Interviewer: Explain that you will now ask the interviewee about his/her knowledge of different } \\
\text { FP methods. } \\
\text { For each one of the next methods, please tell me if you: } \\
\text { I) Know the method sufficiently well to counsel and provide it to a client } \\
\text { 2) Know the method sufficiently well to counsel about it, but not to provide it } \\
\text { 3) Know little about the method and would not feel comfortable counseling or providing } \\
\text { it } \\
\text { 4) Do not know the method }\end{array}$}} \\
\hline & & & & & & \\
\hline & & & & & & \\
\hline & & & & & & \\
\hline & & & & & & \\
\hline & & & & & & \\
\hline & & \begin{tabular}{|l|} 
Know well \\
to counsel \\
and provide \\
it
\end{tabular} & $\begin{array}{l}\text { Know well } \\
\text { to counsel } \\
\text { but not to } \\
\text { provide it }\end{array}$ & $\begin{array}{l}\text { Know little } \\
\text { about it }\end{array}$ & & not know \\
\hline & Combined oral contraceptives & 1 & 2 & 3 & & 4 \\
\hline & Minipills (progestin-only pills) & 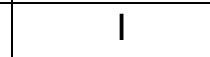 & 2 & 3 & & 4 \\
\hline & Emergency contraceptive pills & I & 2 & 3 & & 4 \\
\hline & Progestin-only injectables & I & 2 & 3 & & 4 \\
\hline & Bi-monthly injectables & $\mathrm{I}$ & 2 & 3 & & 4 \\
\hline & Combined patches & $\mathrm{I}$ & 2 & 3 & & 4 \\
\hline & Jadelle implants & I & 2 & 3 & & 4 \\
\hline & Implanon implants & I & 2 & 3 & & 4 \\
\hline & IUD & I & 2 & 3 & & 4 \\
\hline & Male condoms & 1 & 2 & 3 & & 4 \\
\hline & Female condoms & 1 & 2 & 3 & & 4 \\
\hline & Female sterilization & 1 & 2 & 3 & & 4 \\
\hline & Vasectomy & 1 & 2 & 3 & & 4 \\
\hline & Fertility awareness methods & 1 & 2 & 3 & & 4 \\
\hline & Withdrawal & 1 & 2 & 3 & & 4 \\
\hline & Other: & 1 & 2 & 3 & & 4 \\
\hline \multirow[t]{2}{*}{3.9} & \multirow{2}{*}{$\begin{array}{l}\text { Do you know of any special } \\
\text { consideration to have in mind }\end{array}$} & \multicolumn{4}{|c|}{ No special considerations } & 1 \\
\hline & & \multicolumn{4}{|c|}{ Infection should be ruled out or resolved } & 2 \\
\hline
\end{tabular}




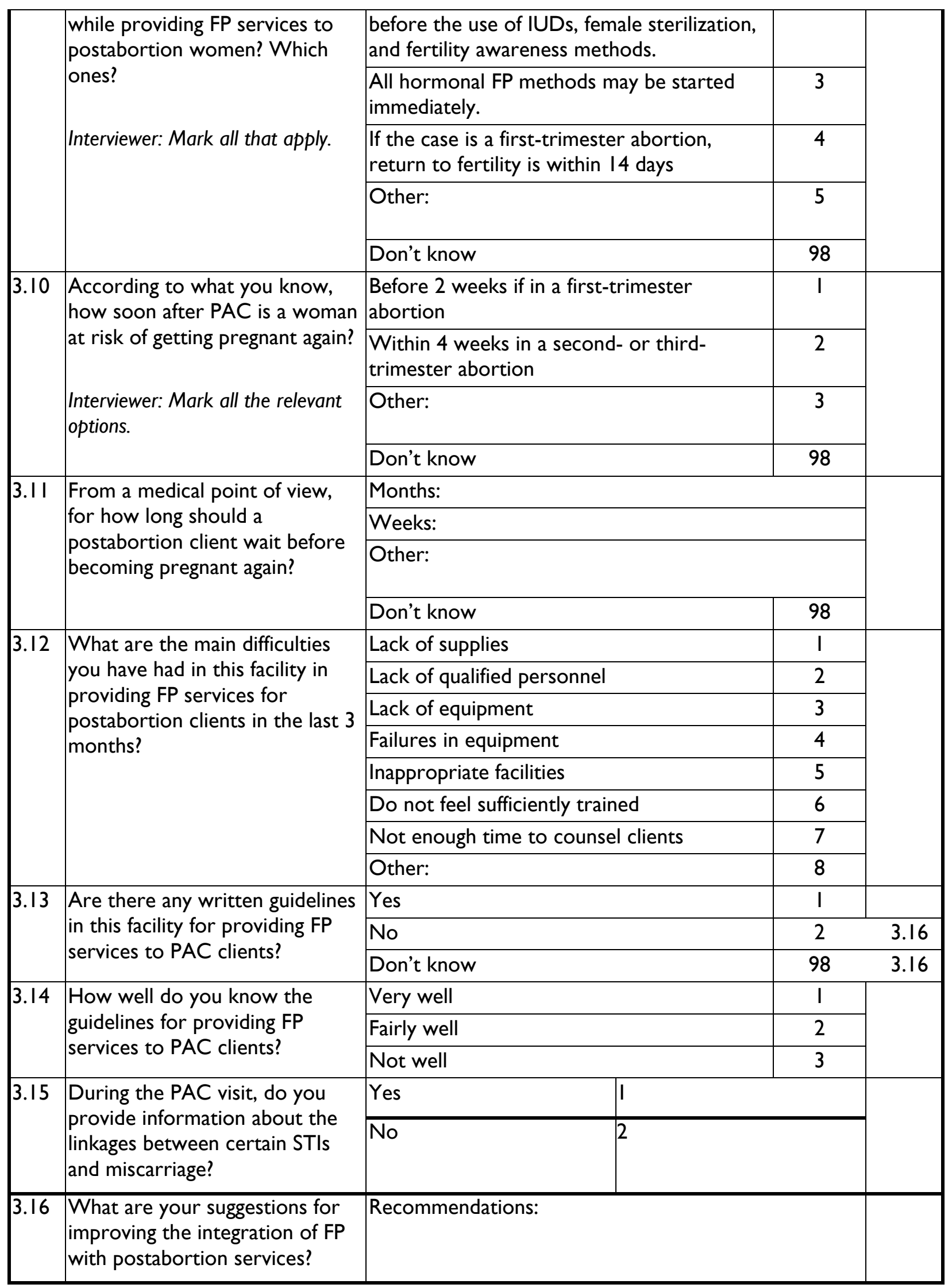


4. PAC experience, knowledge, and practices

\begin{tabular}{|c|c|c|c|c|}
\hline No. & Questions & Coding Categories & & Go to \\
\hline \multirow[t]{2}{*}{4.1} & \multirow{2}{*}{$\begin{array}{l}\text { Are you directly involved in the } \\
\text { clinical treatment of women with } \\
\text { postabortion complications? }\end{array}$} & Yes & $\mathrm{I}$ & \\
\hline & & No & 2 & 4.7 \\
\hline 4.2 & $\begin{array}{l}\text { For how many years in total have } \\
\text { you provided this service, } \\
\text { including your work in other } \\
\text { facilities? }\end{array}$ & $\begin{array}{l}\text { Years: } \\
\text { Interviewer: If less than I year, record "00." }\end{array}$ & & \\
\hline 4.3 & $\begin{array}{l}\text { What types of postabortion } \\
\text { complications are normally seen } \\
\text { within this facility? }\end{array}$ & & & \\
\hline 4.4 & $\begin{array}{l}\text { What would you say is the } \\
\text { average age of women that come } \\
\text { to this facility for PAC services? }\end{array}$ & Average age: & & \\
\hline \multirow[t]{5}{*}{4.5} & \multirow{3}{*}{$\begin{array}{l}\text { Who tends to accompany the } \\
\text { women that come to this health } \\
\text { facility for PAC services? }\end{array}$} & No one & $\mathrm{I}$ & \\
\hline & & Husband/partner & 2 & \\
\hline & & Friend & 3 & \\
\hline & \multirow[t]{2}{*}{ Interviewer: Mark all that apply. } & Relative & 4 & \\
\hline & & Other (specify) & 77 & \\
\hline \multirow[t]{5}{*}{4.6} & \multirow{5}{*}{$\begin{array}{l}\text { Why do you think some women } \\
\text { delay seeking PAC services? }\end{array}$} & Stigma & 1 & \\
\hline & & Provider attitudes & 2 & \\
\hline & & Costs & 3 & \\
\hline & & Don't know where to get services & 4 & \\
\hline & & Other & 77 & \\
\hline 4.7 & $\begin{array}{l}\text { When are referrals offered for } \\
\text { postabortion complications? }\end{array}$ & & & \\
\hline \multirow[t]{3}{*}{4.8} & \multirow{3}{*}{$\begin{array}{l}\text { Do you consider yourself } \\
\text { competent to practice the } \\
\text { following. } \\
\text { Interviewer: Read the options and } \\
\text { mark all the relevant ones. }\end{array}$} & MVA & $\mathrm{I}$ & \\
\hline & & Electric vacuum aspiration & 2 & \\
\hline & & $D \& C$ & 3 & \\
\hline \multirow[t]{4}{*}{4.9} & \multirow{4}{*}{$\begin{array}{l}\text { Which of the following methods } \\
\text { do you personally use to treat } \\
\text { women with incomplete abortions } \\
\text { and abortion complications? }\end{array}$} & MVA & $\mathrm{I}$ & \\
\hline & & $D \& C$ & 2 & \\
\hline & & Abortion with drugs & 3 & \\
\hline & & Other: & 77 & \\
\hline \multirow[t]{2}{*}{4.10} & \multirow{2}{*}{$\begin{array}{l}\text { Do you currently provide } \\
\text { postabortion counseling or } \\
\text { orientation to women in this facility? }\end{array}$} & Yes & I & \\
\hline & & No & 2 & 4.13 \\
\hline
\end{tabular}




\begin{tabular}{|c|c|c|c|}
\hline 4.11 & $\begin{array}{l}\text { For how many years in total have } \\
\text { you provided this service? Please } \\
\text { include your work at other } \\
\text { facilities. }\end{array}$ & $\begin{array}{l}\text { Years: } \\
\text { Interviewer: If less than I year, record "00." }\end{array}$ & \\
\hline \multirow[t]{11}{*}{4.12} & \multirow{3}{*}{$\begin{array}{l}\text { What are the main components of } \\
\text { the counseling and orientation you } \\
\text { offer to postabortion clients? }\end{array}$} & Comfort woman & $\mathrm{I}$ \\
\hline & & Inform about health condition & 2 \\
\hline & & Inform about surgical procedure & 3 \\
\hline & \multirow{8}{*}{ Interviewer: Mark all that apply. } & Inform about post-treatment care & 4 \\
\hline & & Information about pain management & 5 \\
\hline & & Inform about danger signs & 6 \\
\hline & & Counsel about FP & 7 \\
\hline & & Counsel about STIs, HIVIAIDS & 8 \\
\hline & & Respond to questions and concerns & 9 \\
\hline & & Refer to other services & 10 \\
\hline & & Other: & 77 \\
\hline \multirow[t]{6}{*}{4.13} & \multirow{4}{*}{$\begin{array}{l}\text { What are the main } \\
\text { recommendations for personal } \\
\text { care that should be given to } \\
\text { postabortion women? }\end{array}$} & Avoid intense physical activity for 2 to 3 days. & $\mathrm{I}$ \\
\hline & & The medicine they can take to relieve pain & 2 \\
\hline & & To wash the perineum & 3 \\
\hline & & To avoid vaginal sex until bleeding stops & 4 \\
\hline & \multirow[t]{2}{*}{ Interviewer: Mark all relevant options. } & Other: & 77 \\
\hline & & Don't know & 98 \\
\hline \multirow[t]{16}{*}{4.14} & \multirow{3}{*}{$\begin{array}{l}\text { What are the danger signs in the } \\
\text { postabortion period? }\end{array}$} & Increased bleeding & $\mathrm{I}$ \\
\hline & & Bleeding heavier than abnormal period & 2 \\
\hline & & Continued bleeding for 2 weeks & 3 \\
\hline & \multirow[t]{13}{*}{ Interviewer: Mark all that apply. } & Foul-smelling vaginal discharge & 4 \\
\hline & & Severe abdominal pain & 5 \\
\hline & & Fever & 6 \\
\hline & & Chills & 7 \\
\hline & & Muscle aches & 8 \\
\hline & & Tenderness to pressure in the abdomen & 9 \\
\hline & & $\begin{array}{l}\text { Delay (6 weeks or more) in resuming } \\
\text { menstrual period }\end{array}$ & 10 \\
\hline & & Dizziness or fainting & II \\
\hline & & Feeling ill, weakness & 12 \\
\hline & & Nausea or vomiting & 13 \\
\hline & & Severe and constant headache & 14 \\
\hline & & Other: & 77 \\
\hline & & Don't know & 98 \\
\hline
\end{tabular}




\begin{tabular}{|c|c|c|c|c|}
\hline \multirow[t]{9}{*}{4.15} & \multirow{9}{*}{$\begin{array}{l}\text { What are the main difficulties you } \\
\text { have had in this facility in treating } \\
\text { postabortion women in the last } 3 \\
\text { months? }\end{array}$} & Lack of supplies & I & \\
\hline & & Lack of qualified personnel & 2 & \\
\hline & & Lack of equipment & 3 & \\
\hline & & Failures in equipment & 4 & \\
\hline & & Inappropriate facilities & 5 & \\
\hline & & Do not feel adequately trained & 6 & \\
\hline & & Not enough time to treat clients & 7 & \\
\hline & & Other: & 77 & \\
\hline & & Don't know & 98 & \\
\hline \multirow[t]{2}{*}{4.16} & \multirow{2}{*}{$\begin{array}{l}\text { Does this health facility experience } \\
\text { stock-outs of FP commodities? }\end{array}$} & Yes & 1 & \\
\hline & & No & 2 & \\
\hline \multirow[t]{3}{*}{4.17} & \multirow{3}{*}{$\begin{array}{l}\text { Does this health facility have } \\
\text { guidelines for PAC? }\end{array}$} & Yes & 1 & \\
\hline & & No & 2 & $\begin{array}{r}\text { next } \\
\text { section }\end{array}$ \\
\hline & & Don't know & 98 & $\begin{array}{r}\text { next } \\
\text { section }\end{array}$ \\
\hline \multirow[t]{3}{*}{4.18} & \multirow{3}{*}{$\begin{array}{l}\text { How well do you know the } \\
\text { guidelines for PAC? }\end{array}$} & Very well & $\mathrm{I}$ & \\
\hline & & Fairly well & 2 & \\
\hline & & Not well & 3 & \\
\hline
\end{tabular}

5. Suggestions for improving PAC

\begin{tabular}{|c|c|c|c|c|}
\hline \multirow{3}{*}{\begin{tabular}{|l} 
No. \\
5.1
\end{tabular}} & \multirow{3}{*}{$\begin{array}{l}\text { Questions } \\
\text { Do you have any suggestions to } \\
\text { improve your ability to provide } \\
\text { PAC? }\end{array}$} & \multicolumn{2}{|l|}{ Coding Categories } & \multirow[t]{2}{*}{ Go to } \\
\hline & & Yes & $\mathrm{I}$ & \\
\hline & & No & 2 & 5.3 \\
\hline \multirow[t]{4}{*}{5.2} & \multirow{4}{*}{$\begin{array}{l}\text { In what domains would you like to } \\
\text { improve or reinforce your abilities? }\end{array}$} & Uterine evacuation techniques & $\mathrm{I}$ & \\
\hline & & Counseling & 2 & \\
\hline & & Postpartum FP & 3 & \\
\hline & & Other: & 77 & \\
\hline \multirow[t]{10}{*}{5.3} & \multirow{3}{*}{$\begin{array}{l}\text { What would you recommend to } \\
\text { improve PAC in this facility? }\end{array}$} & More medicines and products & I & \\
\hline & & Train/rotate staff & 2 & \\
\hline & & Motivate staff & 3 & \\
\hline & \multirow[t]{7}{*}{ Interviewer: Mark all that apply. } & More staff & 4 & \\
\hline & & Have a special area for PAC & 5 & \\
\hline & & Improve the prevention of infections & 6 & \\
\hline & & Decrease the duration of the treatment & 7 & \\
\hline & & No suggestions & 8 & \\
\hline & & Other & 77 & \\
\hline & & Don't know & 98 & \\
\hline
\end{tabular}


6. Supervision

\begin{tabular}{|c|c|c|c|c|c|}
\hline \multirow{3}{*}{\begin{tabular}{|l} 
No. \\
6.1
\end{tabular}} & \multirow{3}{*}{\begin{tabular}{|l|} 
Questions \\
In the last 6 months, has a \\
supervisor spoken with you about \\
or observed your PAC-related \\
work?
\end{tabular}} & \multicolumn{3}{|l|}{ Coding Categories } & \multirow[t]{2}{*}{ Go to } \\
\hline & & \multicolumn{3}{|l|}{ Yes } & \\
\hline & & \multicolumn{3}{|l|}{ No } & end \\
\hline 6.2 & $\begin{array}{l}\text { How many times in the last } 6 \\
\text { months has your PAC-related work } \\
\text { been supervised? }\end{array}$ & \multicolumn{3}{|l|}{ Number of times: } & \\
\hline \multirow[t]{6}{*}{6.3} & \multicolumn{2}{|c|}{$\begin{array}{l}\text { Did the supervisor do the following the last time she/he } \\
\text { supervised you? }\end{array}$} & Yes & No & \\
\hline & \multicolumn{2}{|l|}{ I) Check your PAC-related records } & $\mathrm{I}$ & 2 & \\
\hline & \multicolumn{2}{|l|}{ 2) Observe your PAC-related work } & $\mathrm{I}$ & 2 & \\
\hline & \multicolumn{2}{|c|}{ 3) Provide feedback on your PAC-related performance } & $\mathrm{I}$ & 2 & \\
\hline & \multicolumn{2}{|c|}{$\begin{array}{l}\text { 4) Provide updates on administrative or technical issues } \\
\text { related to your PAC work }\end{array}$} & $\mathrm{I}$ & 2 & \\
\hline & \multicolumn{2}{|c|}{$\begin{array}{l}\text { 5) Discuss problems you have encountered in the course } \\
\text { of your PAC work }\end{array}$} & $\mathrm{I}$ & 2 & \\
\hline
\end{tabular}

